Division of Geological \& Geophysical Surveys

PRELIMINARY INTERPRETIVE REPORT 2010-1

\title{
ACTIVE AND POTENTIALLY ACTIVE FAULTS IN OR NEAR THE ALASKA HIGHWAY CORRIDOR, DOT LAKE TO TETLIN JUNCTION, ALASKA
}

by

Gary A. Carver, Sean P. Bemis, Diana N. Solie, Sammy R. Castonguay, and Kyle E. Obermiller

September 2010

THIS REPORT HAS NOT BEEN REVIEWED FOR TECHNICAL CONTENT (EXCEPT AS NOTED IN TEXT) OR FOR CONFORMITY TO THE EDITORIAL STANDARDS OF DGGS.

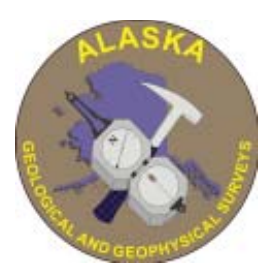

Released by

STATE OF ALASKA DEPARTMENT OF NATURAL RESOURCES Division of Geological \& Geophysical Surveys 3354 College Rd.

Fairbanks, Alaska 99709-3707 



\section{CONTENTS}

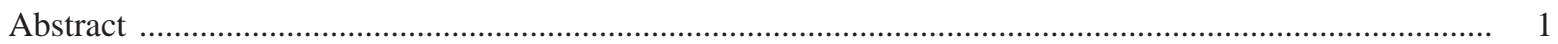

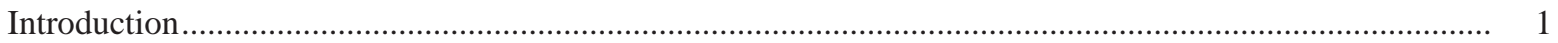

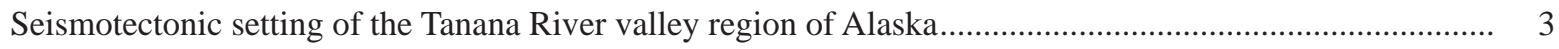

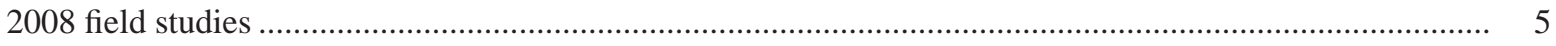

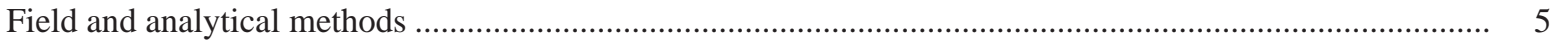

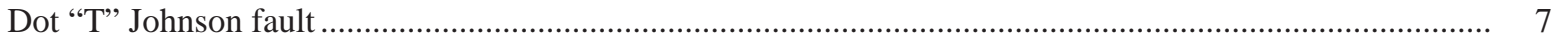

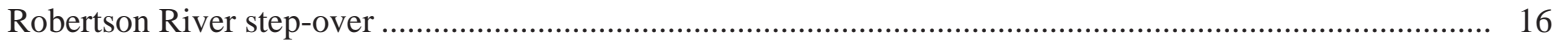

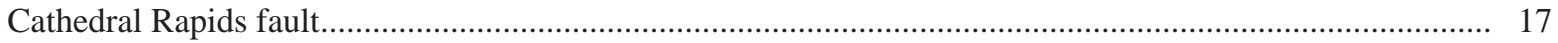

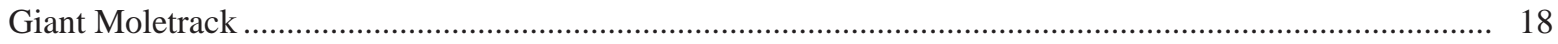

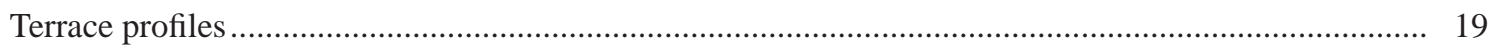

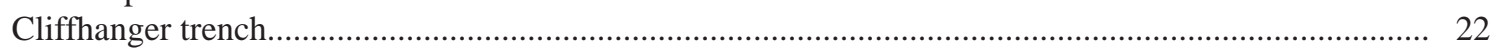

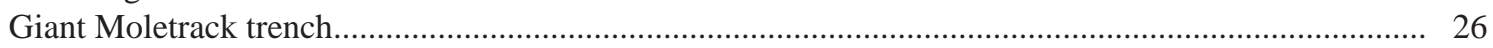

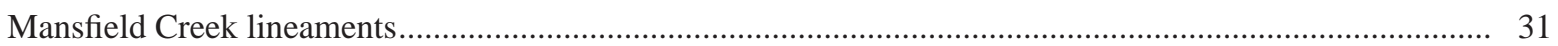

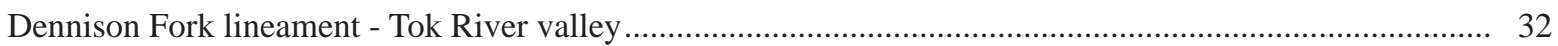

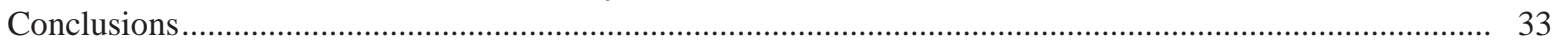

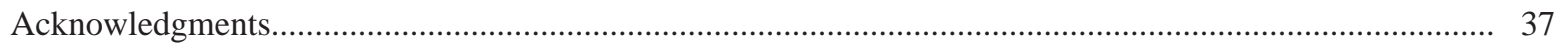

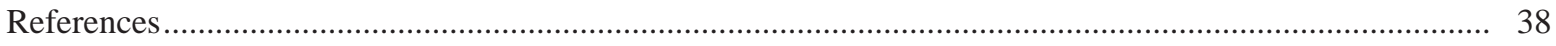

\section{FIGURES}

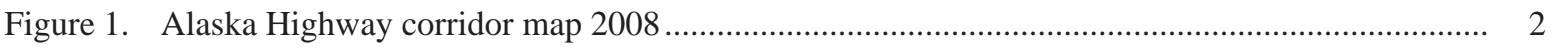

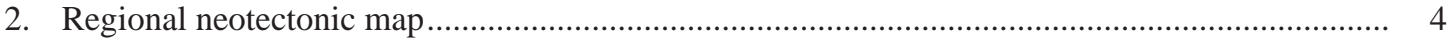

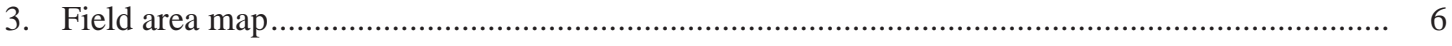

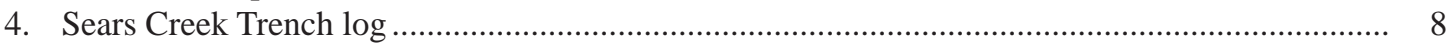

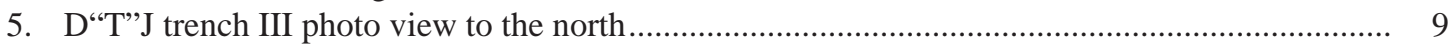

6. Close-up view, meter 7-10, east wall D“T”J III trench .......................................................... 10

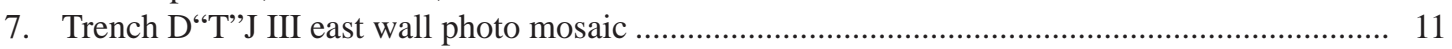

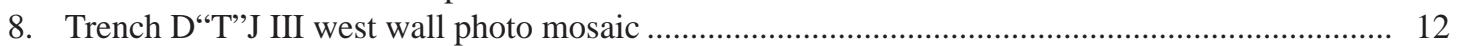

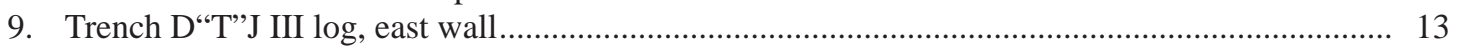

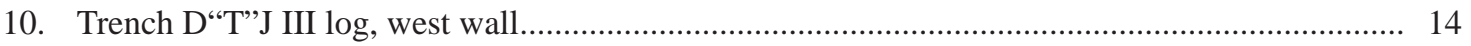

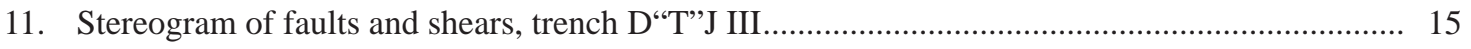

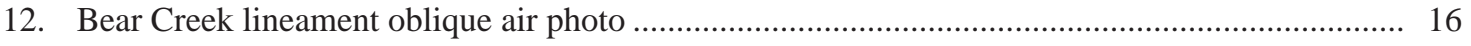

13. Bear Creek lineament trench photo........................................................................... 17

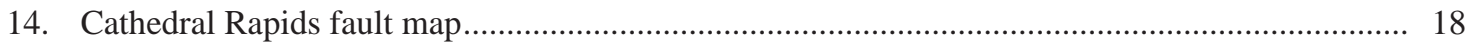

15. Giant Moletrack oblique air photo view to the southeast .................................................... 19

16. AirSAR image and profiles across the Giant Moletrack anticline and Cathedral Rapids

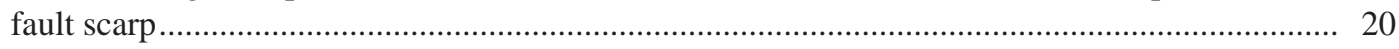

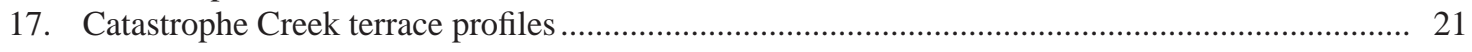

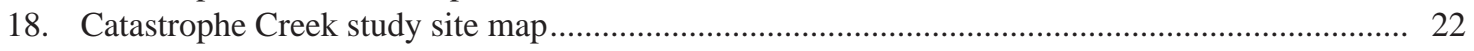

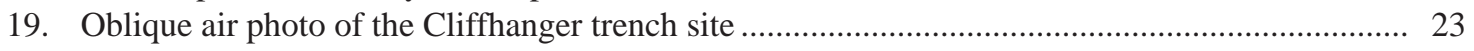

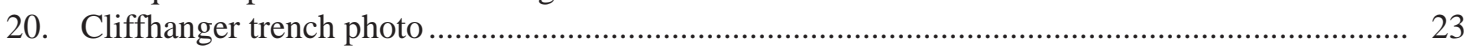

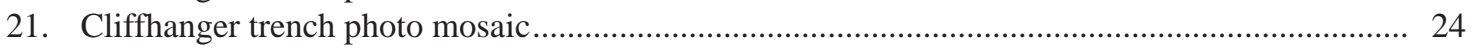

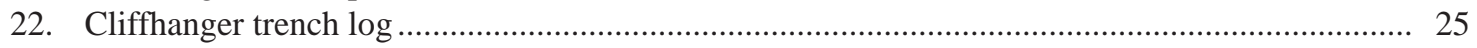

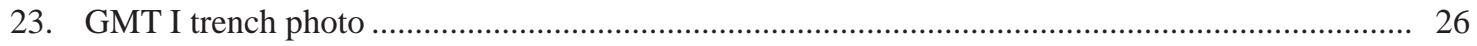

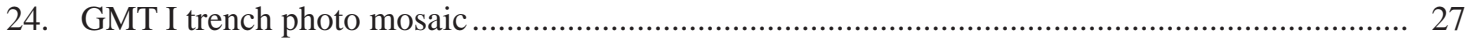

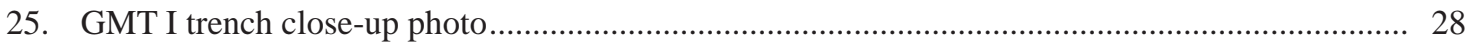

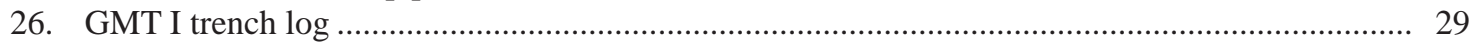

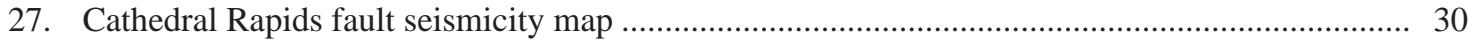

28. Mansfield lineament oblique air photo ........................................................................... 31

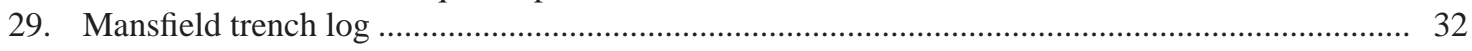

30. Dennison Fork lineament, Tok River valley map ............................................................... 33 
31. Dennison Fork lineament trenches photo mosaics....................................................................... 34

32. Trench I log - Dennison Fork lineament, Tok River valley ............................................................ 35

33. Trench II log - Dennison Fork lineament, Tok River valley .......................................................... 36

\section{TABLES}

Table 1. Location of trench sites excavated as part of active fault investigations.................................... 5

\section{APPENDIX}

${ }^{14} \mathrm{C}$ ages for samples collected from trenches in 2008 ............................................................................. 41 


\title{
ACTIVE AND POTENTIALLY ACTIVE FAULTS IN OR NEAR THE ALASKA HIGHWAY CORRIDOR, DOT LAKE TO TETLIN JUNCTION, ALASKA
}

\author{
by \\ Gary A. Carver ${ }^{1,2}$, Sean P. Bemis ${ }^{3}$, Diana N. Solie ${ }^{4}$, \\ Sammy R. Castonguay ${ }^{3}$, and Kyle E. Obermiller ${ }^{5}$
}

\begin{abstract}
In 2005 the Alaska Division of Geological \& Geophysical Surveys initiated a multi-year geologic field study focused on a corridor centered along the Alaska Highway between Delta Junction and the Canada border. The purpose of this project is to provide geologic information relevant to a proposed Alaska-Canada natural gas pipeline and other future development in the corridor. Identification of active faults and characterization of seismic hazards were included in the project. During the 2006 and 2007 field seasons, lineaments and geologic features indicative of possible youthful surface faulting in or near the western half of the corridor between Delta Junction and Dot Lake were identified and evaluated. Four of the lineaments were found to be active (Holocene) faults. These are: (1) the Dot "T" Johnson fault, a thrust fault on the south side of the Tanana River valley along the base of the Alaska Range, (2) the Canteen fault, a strike-slip tear fault joining segments of the Dot "T" Johnson fault at a left step in the range front in the Little Gerstle River valley, (3) the Panoramic fault, also a left-lateral tear fault connecting the west end of the Dot "T" Johnson fault with the east end of the Donnelly Dome fault at a left step of the Alaska Range on the west flank of Granite Mountain, and (4) the Billy Creek fault, a northeast-trending left normal oblique fault north of the Tanana River valley in the Billy Creek drainage. The Dot " $T$ ”, Johnson fault is interpreted to be an eastern extension of the Northern Foothills Fold and Thrust Belt (NFFTB), a system of active thrusts and fault-generated folds along the northern flank of the Alaska Range west of the Delta River.

During the 2008 field season the active fault studies were focused on the central part of the corridor between Dot Lake and Tetlin Junction. Field studies included helicopter and fixed-wing air reconnaissance augmented by interpretation of stereo air photos, remotely sensed images, ground reconnaissance, and field mapping. Detailed investigations were conducted where the reconnaissance identified lineaments indicative of Holocene surface faulting. In addition, detailed field studies were conducted of several lineaments identified in the published literature as possible active faults. The detailed studies included field mapping, topographic profiling, trenching, and ${ }^{14} \mathrm{C}$ dating of surficial sediments associated with lineaments exhibiting characteristics of active faults. Two faults and a large fault-related anticline were found to have generated late Pleistocene and Holocene surface deformation in the Dot Lake-Tetlin Junction section of the corridor. These structures, the eastern part of the Dot “T”' Johnson fault, the Cathedral Rapids fault, and the Giant Moletrack anticline, are active structures in the eastern part of the NFFTB. Detailed investigation of the Mansfield and Dennison Fork lineaments, identified as candidate active faults in the literature, produced conclusive evidence that they are not active faults. Detailed study of a third suspect lineament, the Bear Creek lineament, was inconclusive.
\end{abstract}

\section{INTRODUCTION}

The Alaska Highway is the principal land transportation route connecting interior Alaska to Canada and the lower 48 United States and is the locus of significant planned and proposed development. In the Tanana River valley between Delta Junction and the Canada border, the Alaska Highway corridor is a 25-km-wide, 320-kmlong swath centered on the highway (fig. 1). The corridor includes proposed routes for an Alaska-Canada natural gas pipeline and an extension of the Alaska Railroad through Canada (Solie and Burns, 2006, 2007). In order to allow informed evaluations of future development plans and guide engineering and design decisions regarding the proposed natural gas pipeline, the Alaska railroad extension, and other development in the corridor, the State

${ }^{1}$ Department of Geology, Humboldt State University, Emeritus, Arcata, CA 95521; cgeol@acsalaska.net

${ }^{2}$ Carver Geologic Inc., Kodiak, AK 99615

${ }^{3}$ Department of Geological Sciences, 1272 University of Oregon, Eugene, OR 97403

${ }^{4}$ Baseline Geoconsulting, LLC. P.O. Box 82293, Fairbanks, AK 99708-2293

${ }^{5}$ Department of Geological Engineering, University of Alaska, Fairbanks, AK 99775 


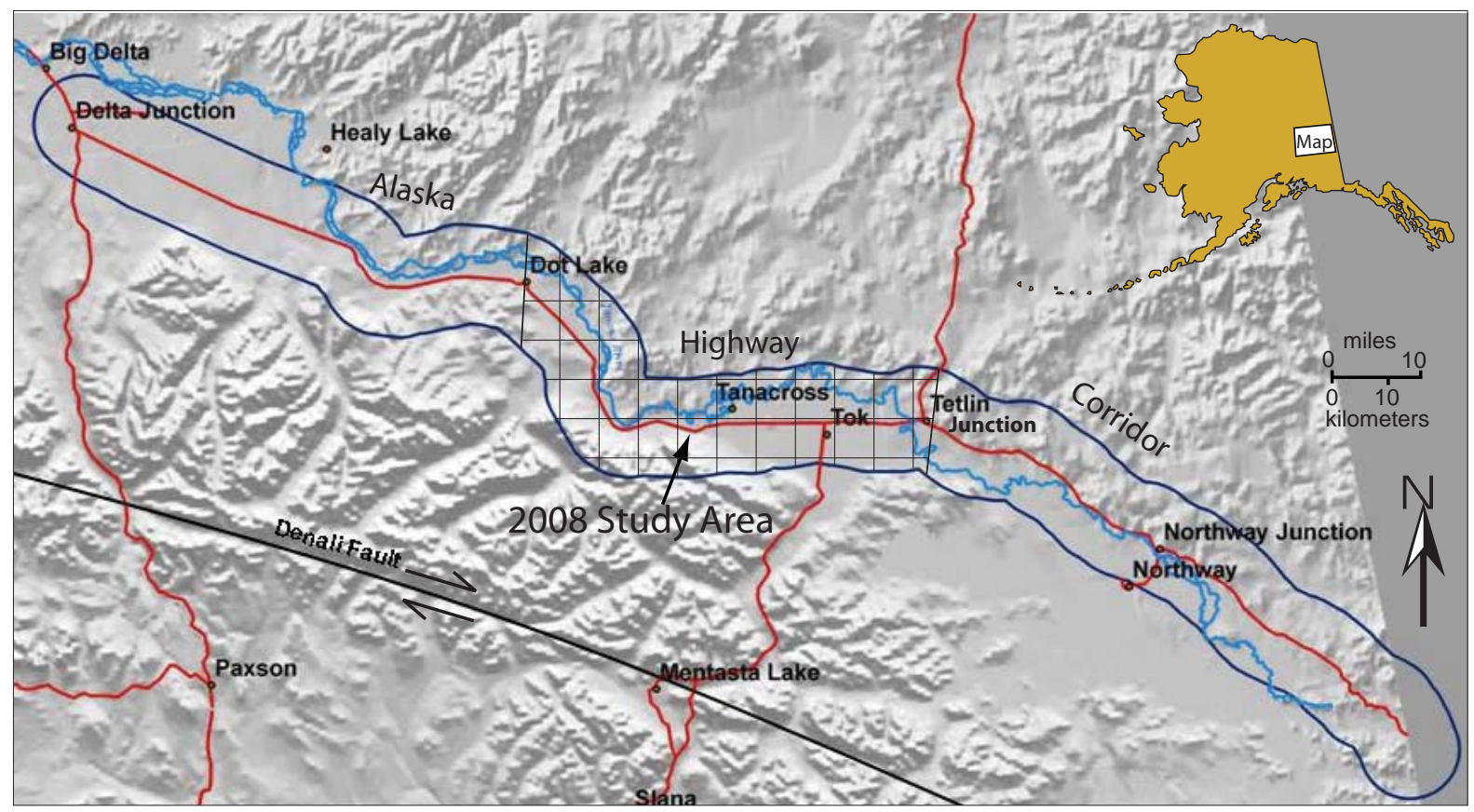

Figure 1. The Alaska Highway corridor is a 25-km-wide, 320-km-long area centered on the Alaska Highway between Delta Junction and the Canada border where the Alaska Division of Geological \& Geophysical Surveys (DGGS) is conducting field studies to develop information about the geology in support of proposed development including the Alaska-Canada natural gas pipeline and an extension of the Alaska Railroad through Canada. During the 2008 field season the studies were focused on the central part of the corridor between Dot Lake and Tetlin Junction.

Legislature in 2005 authorized a multi-year geologic framework assessment project to be conducted by the Alaska Division of Geological \& Geophysical Surveys (DGGS). One of the components of the project includes mapping and characterization of active and potentially active faults in and near the Alaska Highway corridor. This report summarizes the active and potentially active fault studies of the framework project conducted in the central section of the corridor between Dot Lake and Tetlin Junction during the 2008 field season, and presents the preliminary results and conclusions from these investigations.

Active faults are defined as those that show evidence of surface displacement during the Holocene (last 11,000 years), and have the potential for future movement. This report summarizes results of studies of active and potentially active faults conducted during the 2008 field season in and adjacent to the central section of the corridor that could impact existing and future development. The studies in 2008 build on mapping and field investigations of the western section of the Alaska Highway corridor completed in 2006 and 2007 (Carver and others, 2008). These studies are intended to guide users to information about specific active and potentially active faults in the region. Applications of this information to specific development projects may require additional investigation to more thoroughly determine fault locations and displacement parameters. Due to the reconnaissance nature of this work, additional active faults may be found in the region with more detailed mapping and study. In this report, in order to distinguish active and potentially active faults from inactive faults other lineaments, we have reserved the term "active fault" for those on which we observe evidence of recent (Holocene) movement. The term "lineament" as used in this report includes (a) active faults not yet recognized as such, (b) older faults that ceased activity more than 11,000 years ago, and (c) linear features on air photos and remotely sensed images that are not related to faulting. 


\section{SEISMOTECTONIC SETTING OF THE TANANA RIVER VALLEY REGION OF ALASKA}

The active tectonics of interior Alaska is driven by the $\sim 65 \mathrm{~mm} / \mathrm{yr}$ north-northwest convergence of the Pacific and North American plates. The process that transfers tectonic forces inland from the Pacific plate to the interior of Alaska is complex and not well understood. It involves effects of an ongoing collision between the internally deforming Yakutat microplate and counter-clockwise rotation of the Wrangell microplate, two recently identified crustal blocks that comprise part of the complex North American-Pacific plate boundary (Chapman and others, 2008; Freymueller and others, 2008). The Denali-Totschunda fault system defines the broadly arcuate northern boundary of the Wrangell microplate (Haeussler, 2008). Right-lateral slip along the Denali-Totschunda fault system accommodates the rotation of the Wrangell microplate in south-central and southwestern Alaska (fig. 2). The slip rates on the central Denali fault, source of the 2002 M7.9 Denali fault earthquake, are about 9 to $14 \mathrm{~mm} / \mathrm{yr}$ (Matmon and others, 2006).

Quaternary uplift, youthful faulting and folding in the Alaska Range, subsidence of the Tanana lowlands, and significant levels of seismicity as far north as the southern margin of the Brooks Range are evidence of active tectonics in central Alaska. Right-lateral slip on the Denali fault accommodates much of the westward component of motion of the Yakataga and Wrangell microplates. A component of north-directed contraction is transferred across the Denali fault and accommodated by east-west-oriented youthful thrust faults and folds in the foothills region on the north flank of the Alaska Range. These youthful folds and faults compose the Northern Foothills Fold and Thrust Belt (NFFTB) (Ridgway and others, 2002; Bemis, 2004; Carver and others, 2008). West of the corridor study area between the Delta River and Denali National Park and Preserve, the $~ 50-\mathrm{km}$-wide NFFTB imparts a pronounced east-west grain to the topography (fig. 2). North-flowing rivers heading in the Alaska Range are antecedent to the folds and faults and their long profiles display perturbations related to active growth of these structures (Bemis, 2004; Carver and others, 2006, Bemis and Wallace, 2007; Lesh and Ridgway, 2007; Carver and others, 2008). The folds and faults deform late Neogene and Quaternary alluvial surfaces and fluvial terraces. Shortening across the NFFTB near the Nenana River, based on a balanced cross-section analysis of deformed late Tertiary Usibelli Group and Nenana Gravel, is about $8.8 \mathrm{~km}$ (Bemis, 2004). Assuming the onset of thrust faulting and folding in the region coincided with the end of deposition of the Nenana Gravel about 3 my ago, the average shortening rate across the NFFTB in the vicinity of the Nenana River is at least $3 \mathrm{~mm} / \mathrm{yr}$ (Bemis, 2004; Bemis and Wallace, 2007). Seismicity in the northern foothills region supports this interpretation (Doser, 2004). Reconnaissance of the thrust faults between the Delta and Nenana rivers shows many are marked by steep, uneroded scarps in late Pleistocene and Holocene sediments (Bemis, 2004; Carver and others, 2006, 2008).

West of the corridor study area, the northern foothills of the Alaska Range are bordered on the north by the actively subsiding Tanana foreland basin that underlies an extensive alluvial and swampy lowland comprising the Tanana River valley (Ridgway and others, 2002). The Tanana basin narrows and shallows to the east in the vicinity of the study area and the north side of the basin bounds the Yukon-Tanana Upland, a region of low hills and mountains dissected by mature drainages. Seismicity north of the northern foothills includes several northeasttrending zones of shallow seismicity that include five historic earthquakes between M6 and M7.3 (Ruppert and others, 2008). In the Fairbanks region these include the Minto Flats, Fairbanks, and Salcha seismic zones (fig. 2). Focal mechanisms for earthquakes in these seismic zones are dominantly left lateral (Ratchkovski and Hansen, 2002). The largest was a M7.3 in 1937 in the Salcha seismic zone. East of Fairbanks, northeast-oriented streams parallel to the seismic belts suggest structural control of the drainage along faults. The northeast-trending seismic zones and faults are interpreted to reflect deformation from clockwise horizontal rotation of fault-bounded blocks between the Denali and Tintina fault systems (Page and others, 1995; Lesh and Ridgway, 2007).

Upper crustal seismicity in the Tanana River valley region includes many earthquakes in the Alaska Range and NFFTB west of the study area and modest seismicity along the Denali fault south of the corridor, but few earthquakes have been located within the corridor (fig. 2). The seismicity shown on figure 2 is from the National Earthquake Information Service (NEIS) database for the period 1979 to 2002. To provide a view of the regional background seismicity, we have not included the main shocks (M6.7 and 7.9) or aftershocks from the 2002 Denali fault earthquake sequence. It is noteworthy that the seismicity in the northern foothills region west of the study area is similar to the northern flank of the Alaska Range adjacent to the corridor.

The 2002 Denali fault earthquake sequence generated surface displacement on the previously unknown Susitna Glacier fault, the central section of the Denali fault, and the northern part of the Totschunda fault (fig. 2) (Eberhart-Phillips and others, 2003). Surface displacement also occurred on part of the central section of the Denali fault near the Delta River in 1912 (Carver and others, 2004). No other historic surface faulting events are known in central Alaska. 


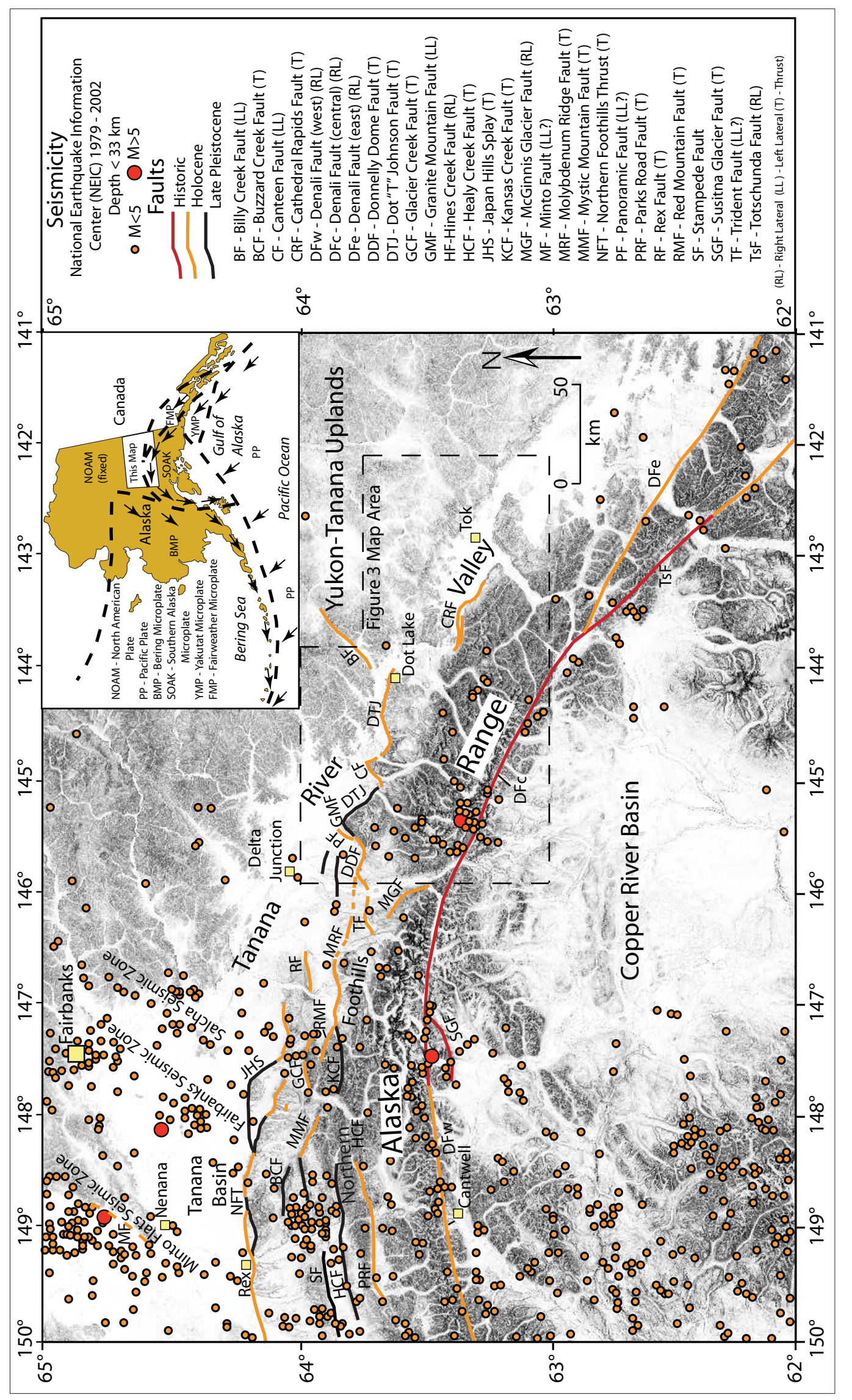

$\Xi$ ภंड

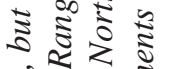

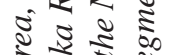
उ) से से 每 $\frac{0}{2} \frac{2}{2}$

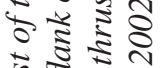
ญ इี

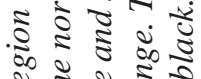
ญ ฐ ฐ ฐ ธิธี ธี

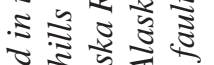

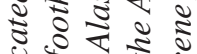
¿ $\leftleftarrows 00$

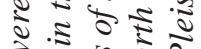

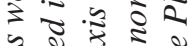

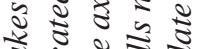
는즌

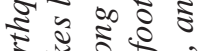

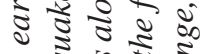

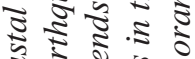
ระ 范

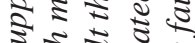

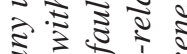
है

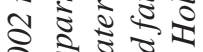
ते कि के के क्ष के 20.5 $\rightarrow$ ㄹำ

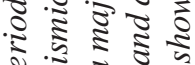
๘

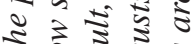

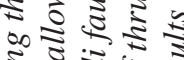

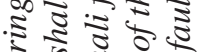

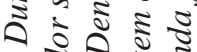

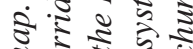
हो वे के प्र วิ

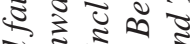
ธิ จำ ธิ

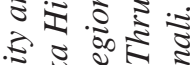
क्ष ฟิ ปิ ปั

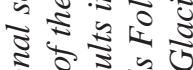

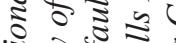
จ.

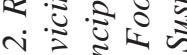
๖ईฐई 
Recent mapping in the northern foothills of the Alaska Range has identified a number of faults with late Pleistocene and Holocene displacement (fig. 2) (Bemis, 2004, 2006; Thoms, 2005; Carver and others, 2006, 2008). The majority of these are relatively low-slip-rate thrust faults interpreted to accommodate regional north-south-directed contraction resulting from convergence of the Pacific plate and collision of the Yakataga block in southeastern and south-central Alaska with the North American plate north of the Denali fault.

During the 2007 corridor studies, we documented four faults with Holocene displacement: the Panoramic, Canteen, Dot "T" Johnson, and Billy Creek faults (Carver and others, 2008). The Dot "T" Johnson fault is a generally east-west-trending, south-dipping, low-angle thrust fault that borders the northern flank of the Alaska Range along the southern margin of the Tanana River valley. It is interpreted to be part of the eastern extension of the NFFTB. The Panoramic and Canteen faults are north-trending left-oblique-slip faults. The Panoramic and Granite Mountain faults connect the east end of the Donnelly Dome fault and the west end of the Dot "T" Johnson fault where the range front steps left about $15 \mathrm{~km}$ along the northwestern flank of Granite Mountain (fig. 2). The left-lateral Canteen fault joins left-stepping segments of the Dot "T" Johnson thrust fault. The Billy Creek fault is a left-lateral strike-slip fault on the north side of the Tanana River valley. This fault has a northeast trend parallel to the Minto Flats, Fairbanks, and Salcha seismic zones.

\section{FIELD STUDIES}

During the summer of 2008, field studies and mapping focused on the section of the Alaska Highway corridor between the village of Dot Lake and Tetlin Junction (fig. 1). Field efforts included trenching investigation of the eastern part of the Dot "T" Johnson fault and evaluation of lineaments identified as potentially active faults in the published and unpublished literature and maps. We also analyzed stereo air photos and conducted helicopter reconnaissance covering the Dot Lake to Tetlin Junction section of the corridor and adjacent parts of the Alaska Range and Yukon-Tanana Uplands to identify additional linear features indicative of geologically youthful faults and surface folds not reported in the literature. Although many lineaments were observed during the helicopter reconnaissance, few exhibited morphology or other geologic evidence of Holocene surface faulting or folding. The reconnaissance resulted in selection of six sites for detailed study. These are the eastern end of the Dot "T" Johnson fault near Dot Lake, the previously unrecognized Cathedral Rapids fault, its associated Giant Moletrack anticline, and the Mansfield, Bear Creek, and Dennison Fork lineaments (fig. 3). AirSAR digital images were used to help map and measure deformation associated with the eastern end of the Cathedral Rapids fault and the Giant Moletrack anticline.

\section{FIELD AND ANALYTICAL METHODS}

All field location coordinates were collected using a handheld GPS unit (no differential correction was applied). Where lineaments with field characteristics indicative of active or potentially active faults were identified, the features were mapped by low-altitude helicopter overflights with GPS coordinates taken at closely spaced intervals along the lineaments. GPS locations were also taken where surface fieldwork, including topographic profiling and trenching, was performed. Table 1 presents UTM coordinates (based on the Clark 1866 spheroid, NAD 27 datum, UTM zone 6 or 7 projections) for the trench sites.

Trench sites were chosen to transect features suspected to be active faults, to expose a cross-sectional view of faults and the most recent stratigraphy.

Table 1. Location of trench sites excavated as part of active fault investigation.

Trench site locations

Sears Creek trench

DTJ III trench

GMT I trench

Cliffhanger trench

Dennison Fork Tok trench I

Dennison Fork Tok trench II

Mansfield Scarp trench

Bear Creek trench
UTM; NAD 27

6 V 6252297064849

6 V 6381027064659

7 V 3798317023325

7 V 3798317023325

7 V 3805566999341

7 V 3805316999311

7 V 3902217064121

6 V 6475037053411

Trenches across the Dot "T" Johnson

fault (Sears Creek and D“T”J III) and the Dennison Fork lineament (Dennison Fork lineament-Tok River valley trenches I and II) were dug with a large, track-mounted excavator. Trenches at the Mansfield scarp and Bear Creek lineament sites as well as the Dot "T" Johnson trenches I and II and the Giant Moletrack and Cliffhanger trenches at the Catastrophe Creek site were inaccessible to motorized excavation equipment. These trenches were hand dug. To facilitate field interpretation and logging we used nails to pin colored flagging along exposed contacts and 

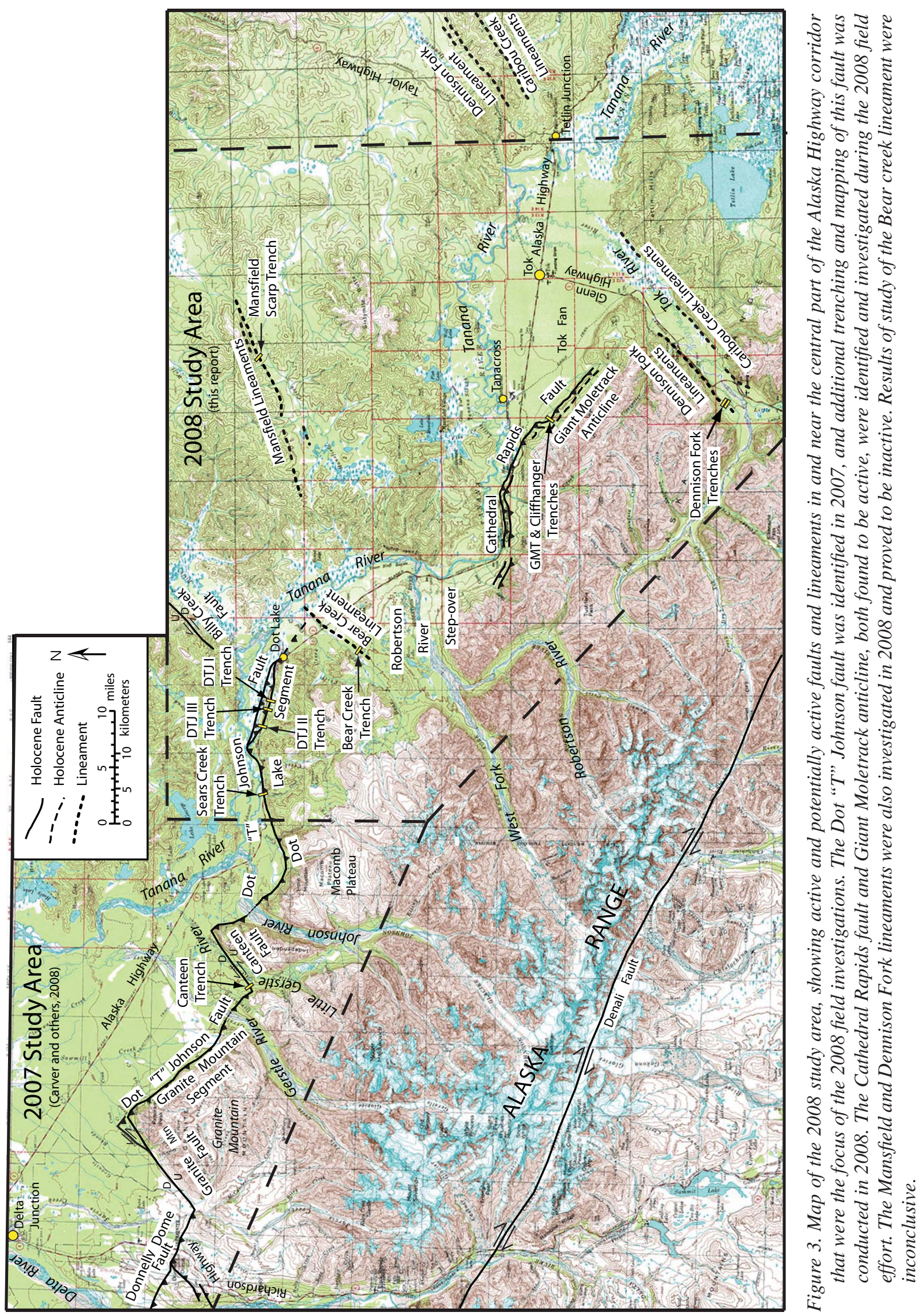
faults on the cleaned trench walls except at the Sears Creek site where the instability of the trench walls required contacts to be delineated with spray paint. Logging of the trench walls was done by placing a grid of horizontal and vertical string lines over the exposed trench wall. The grid was used to accurately measure and transfer each feature to cross section Mylar. Each stratigraphic layer and feature of interest was described and locations of radiocarbon samples were recorded. Soil and sediment colors for each stratigraphic unit were defined using a Munsell Soil Color chart. Where possible, we collected radiocarbon samples from layers bounding faulting events to bracket the age of paleo-earthquakes interpreted from the stratigraphy. Upon completion, we backfilled the trenches, recontoured the trench sites and replaced the natural vegetation.

The radiocarbon samples were carefully extracted to minimize contamination. Samples were air dried and stored in the field in aluminum foil bindles placed in labeled plastic bags. The dry samples were transferred to labeled glass vials after leaving the field. Before being sent to the laboratory for analyses, each sample was inspected through a binocular microscope, picked clean of mineral debris, and for some samples individual plant macrofossils or charcoal grains were separated for analysis. Beta Analytic Radiocarbon Dating Laboratory in Miami, Florida, performed the radiocarbon age analyses on the ${ }^{14} \mathrm{C}$ samples. All analysis was done using AMS methods and included ${ }^{13} \mathrm{C}$ corrections. Laboratory ages were calibrated using the IntCal 04 calibration curve (Reimer and others, 2004). All ages are reported as calibrated two sigma ranges before present (cal BP). The lab age, dating method, material dated, paleoseismic significance, sample and lab numbers, ${ }^{13} \mathrm{C} /{ }^{14} \mathrm{C}$ ratio, and two-sigma calendar calibration age ranges for each of the radiocarbon samples are shown in Appendix I.

Scarp profiles and slope profiles across lineaments and scarps were measured using a hand level stabilized on an instrument rod of known height and vertical distances between survey points (foresites and backsites) read from horizontal sightings on a stadia-surveying rod. At the Catastrophe Creek site the stream thalweg and terrace profile data were collected across the Giant Moletrack anticline with a handheld Trimble GeoXH using the Terrasync collection software, and post-processed against three continuously operating GPS stations within $120 \mathrm{~km}$ of the site. We also conducted a hand leveling survey along the part of terrace T4 near the fault tip where it was strongly deformed in the forelimb of the anticline. Slope distances were measured with a $50 \mathrm{~m}$ tape. Horizontal distances were calculated and slope and scarp profiles were plotted from the hand level and GPS survey measurements.

\section{DOT “T” JOHNSON FAULT}

The Dot "T" Johnson fault is an active, south-dipping thrust fault that daylights along the southern margin of the Tanana River valley between Granite Mountain and Dot Lake (figs. 2 and 3) (Carver and others, 2008). The fault is the eastern extension of the Donnelly Dome fault and the principal fault in the previously unmapped eastern continuation of the NFFTB. The west end of the Dot "T" Johnson fault is connected with the east end of the Donnelly Dome fault by the left-normal-oblique Granite Mountain and Panoramic faults (fig. 2).

The Dot "T" Johnson fault is approximately $80 \mathrm{~km}$ long with two distinct segments, the Granite Mountain and Dot Lake segments (30 and $50 \mathrm{~km}$ long, respectively). The segments are separated by a $10 \mathrm{~km}$ left step along the Little Gerstle River, where they are connected by the left-lateral Canteen fault (Carver and others, 2008). At the east end of the Dot Lake segment, between Berry Creek and Dot Lake, the fault forms a 1-km-wide, 10-km-long pop-up thrust wedge. In 2007 two hand-dug trenches (Dot “T” Johnson I and II, fig. 3) were excavated across a down-to-the-south 3-5-m-high moletrack scarp on the south side of the pop-up wedge (Carver and others, 2008). Detrital charcoal from faulted loess between two colluvial wedges exposed in one of the trenches (D“T”J I, fig. 3) yielded ${ }^{14} \mathrm{C}$ ages that document two episodes of early Holocene faulting (Carver and others, 2008).

Two additional trenches were dug with a large track-mounted excavator across the Dot "T" Johnson fault during the 2008 field season, the Sears Creek and D“T”J III trenches (fig. 3). The Sears Creek trench was located across a 2-m-high north-facing scarp about $20 \mathrm{~m}$ north of the Alaska Highway and $100 \mathrm{~m}$ west of Sears Creek. The trench exposed a south-dipping low-angle thrust fault that offsets interbeds and lenses of fluvial sand, gravel, and overlying silt and loess (fig. 4).

The fault truncates beds and lenses in both the hanging wall and footwall and is marked in the trench by a single 2-4-cm-wide planar zone of mixed silt and sandy silt containing tabular pebbles and cobbles aligned along the fault (fig. 4). The fault dips $12^{\circ}$ to $14^{\circ}$ to the south and daylights at the base of the scarp. No secondary or branch faults were observed in the trench. Beds could not be matched across the fault in the 1.5-m-high trench wall exposures, and no evidence of multiple slip episodes were found in the trench, suggesting the dip-slip displacement on the most recent event was at least $3 \mathrm{~m}$ and resulted from a single earthquake. No organic material was found in the fluvial gravels, but detrital charcoal recovered from the base of the overlying silt and loess yielded ${ }^{14} \mathrm{C}$ ages that limit the fault displacement to more recent than 4,430-3,230 cal BP. The base of an unfaulted organic mat capping the silt and loess dated to 650-560 cal BP. 


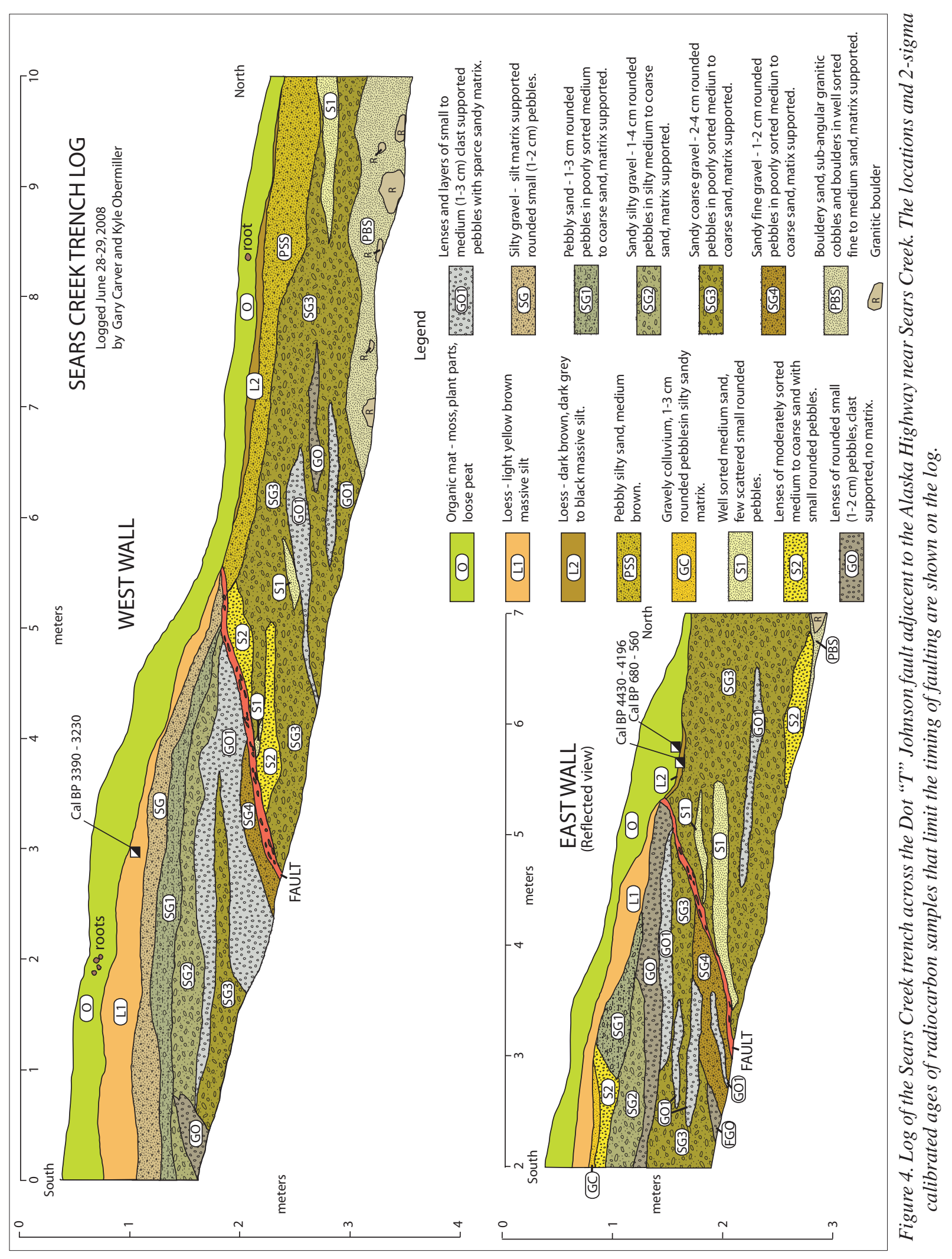


The second trench excavated across the Dot “T” Johnson fault (trench D“T”J III) during the 2008 field season was about $300 \mathrm{~m}$ west of trench D“T”J I, where the moletrack scarp transitions into a 4-m-high, south-facing planar scarp. The trench was excavated in three sections, a 10-m-long, 2-m-deep north section in the hanging wall above the crest of the scarp, a 9-m-long, 3.5-m-deep benched middle section across the scarp, and an 8-m-long, 2-m-deep south section in the footwall (figs. 5-8).

It was not possible to accurately map discrete time-stratigraphic units throughout the trench because the stratigraphy exposed in the trench is very complex, especially in the hanging wall, where it is strongly deformed. Instead we delineated rock-stratigraphic units based on sediment texture and composition and defined these units in a generalized time-stratigraphic context. The oldest stratigraphy exposed in the trench walls consists primarily of interbedded, thin, well-sorted medium and coarse sand deposits with pebble and cobble basal lags. These deposits represent three unconformable packages (oldest to youngest: Ccc and S2; Cms and $\mathrm{S} 1$; Cc and Cs/Vcs) that are interpreted to be glaciofluvial deposits laid down during large outburst floods (Reger and others, 2009). Although no datable material was found in the flood sands, they were likely deposited during the maximum extent of the Donnelly glaciation last glacial maximum (LGM) about 20 ka.

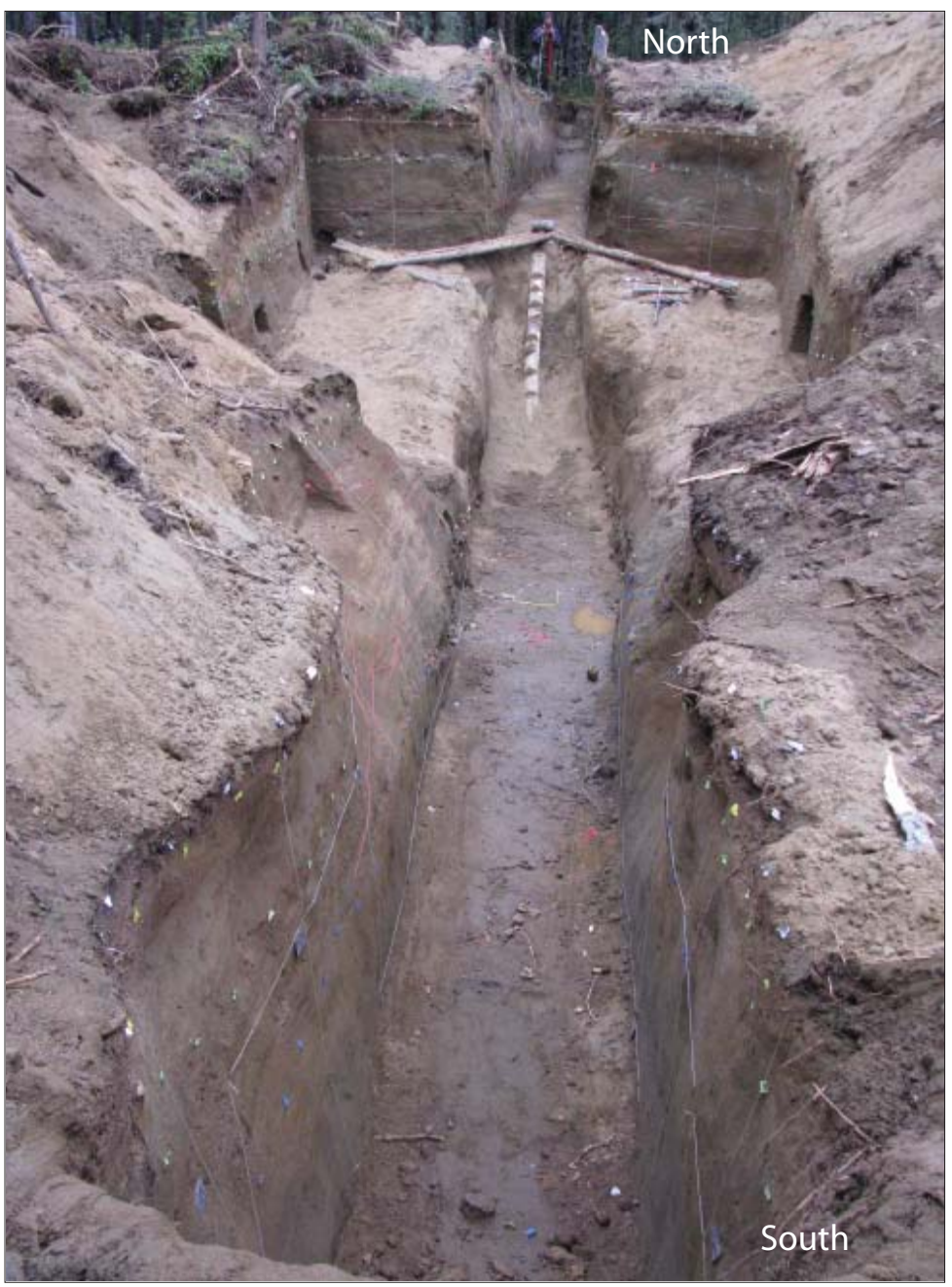

Figure 5. Dot “T” Johnson trench $D$ “T”J III viewed from the south. The trench consisted of a benched central part with shallower unbenched north and south sections. Two people are standing at the north end of the trench for scale.

Two folded and locally overturned sequences of thinly bedded silt, silty sand, poorly sorted to well sorted fine and medium sand and well sorted coarse to very coarse sand (folded sequences 1 and 2, figs. 9 and 10) are stratigraphically above the flood deposits. These folded sequences appear to be preserved in fault-bounded detached fold noses above the main thrust, a nearly horizontal shear zone that extends through the coarse sand of unit Cs. This shear zone is shown on the trench logs as unit Sz (figs. 9 and 10). We speculate that this unit of loose coarse sand has low shear strength, acted as a stress guide, and controlled the location of the principal fault displacement.

An upper sequence of interbedded fluvial silt and well sorted fine and medium sand (units Ms, Fs, Vfs, and Si) also overlies the flood deposits. In the hanging wall, sediments of the upper sequence are highly deformed, probably by cryogenic processes and liquefaction. Radiocarbon ages of 12,840-12,650 and 11,350-11,210 cal BP were obtained from small fragments of detrital charcoal in the deformed fine-grained fluvial silt (unit Si, figs. 9 and 10). A sandy deposit (unit C), interpreted to be colluvium, unconformably overlies the upper sequence of fluvial sands and the folded sequences (figs. 9 and 10). A ${ }^{14} \mathrm{C}$ age of 7,980-7,850 cal BP was obtained from a small fragment of detrital charcoal found at the base of unit C. The sand is capped by a layer of loess (unit S) with weak A-C soil development and a 20-30-cm-thick organic mat.

A nearly horizontal zone of closely spaced micro-faults and shears in the coarse flood sand (unit Sz) defines the principal thrust exposed in the trench. This shear zone dips very gently $\left(15^{\circ}-25^{\circ}\right)$ to the north in the northern end of the trench beneath the uplifted hanging wall and becomes nearly horizontal or slightly south-dipping under 
the scarp. The shear zone is more than a meter thick in the north part of the trench and thins beneath the scarp to a tapered fault tip beneath the toe of the scarp. The fault does not daylight, but ends at the fault tip in the top of the flood deposits about a meter beneath the ground surface. Overlying fluvial and colluvial sediments and soil are warped up over the tapered shear zone and fault tip. The geometry of the shear zone indicates much of the growth of the scarp has resulted from internal thickening of the shear zone by nearly horizontal thrust displacement on the closely spaced micro-faults and inter-granular shears in the coarse flood sands. The dip of micro-faults and shears in the primary thrust zone were between about $10^{\circ}$ and $25^{\circ}$ and their average strike about $\mathrm{N} 28^{\circ} \mathrm{W}$, nearly perpendicular to the $\mathrm{N} 70^{\circ} \mathrm{E}$ trend of the scarp (fig. 11).

Faults exposed in the trench include both south- and north-dipping, small displacement, secondary conjugate thrusts in the hanging wall above the low-angle zone of closely spaced micro-faults and shears that composed the primary thrust (fig. 6). Dip-slip displacement of the folded sequences and upper fluvial sands on these secondary faults range from a few centimeters to more than a meter, showing that part of the total displacement on the fault is accommodated by hanging-wall deformation. Some of the conjugate faults offset the upper sequence of fluvial silts and sands (units Ms, Fs, Vfs, and Si; figs. 8 and 10) and the contact between the upper sequence of fluvial silt and sand and the underlying flood deposits (units Vcs) on discrete faults, but they could not be traced as well defined fault planes down through the flood sand, probably because the very-coarse-grained flood sand deformed internally by distributed inter-granular shear. Dips on most of the secondary conjugate faults range from about $20^{\circ}$ to $50^{\circ}$ (fig. 11). The secondary conjugate fault pattern defines a principal compression axis (sigma 1 ) of about $\mathrm{N} 21^{\circ} \mathrm{W}$, also nearly perpendicular to the $\mathrm{N} 70^{\circ} \mathrm{E}$ trend of the scarp (fig. 11). Both the secondary hanging-wall conjugate faults and the micro-faults and shears in the principal thrust zone indicate a maximum compression direction (sigma 1 ) of north $21^{\circ}$ to $28^{\circ}$ west.

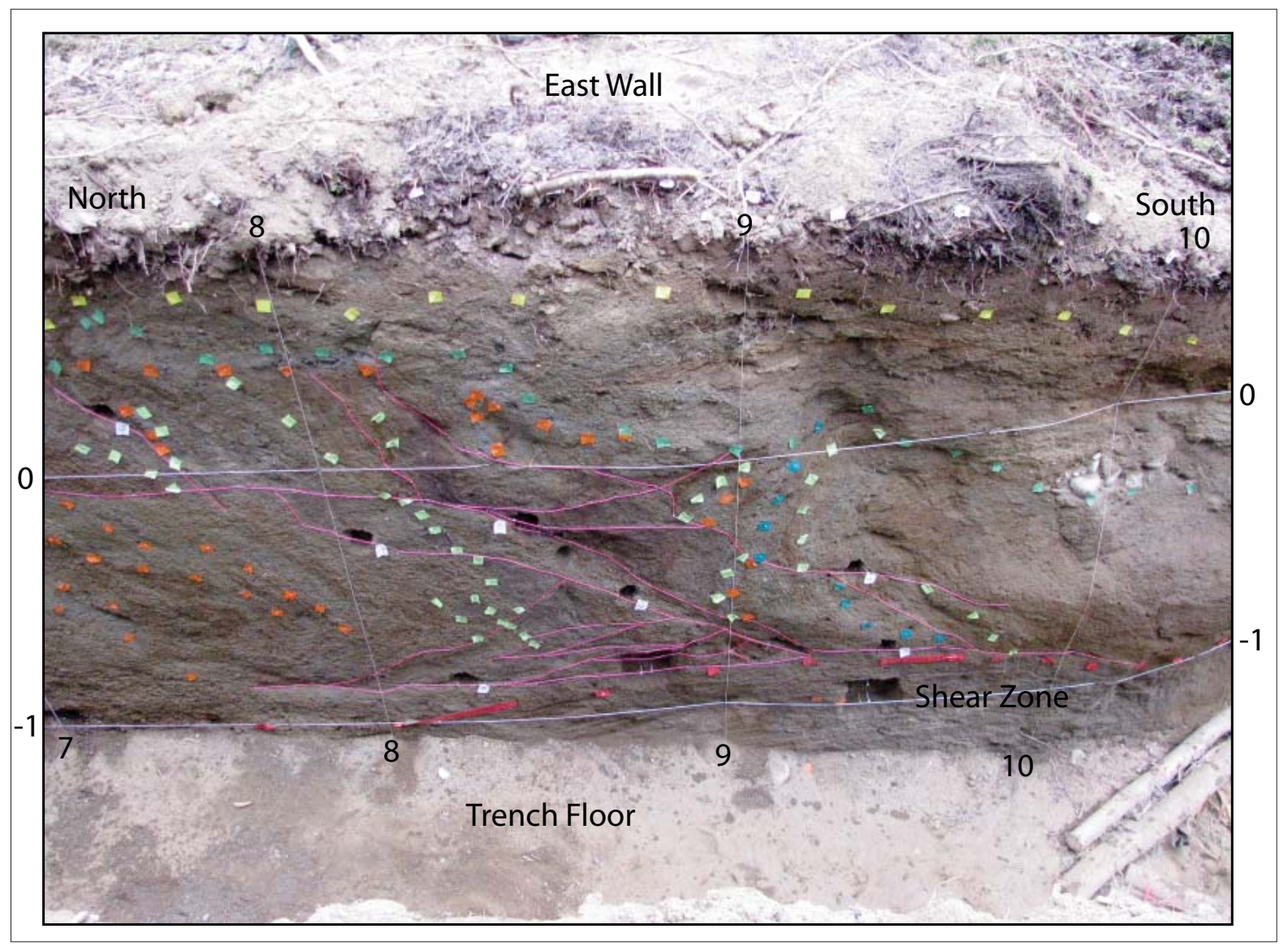

Figure 6. Close-up view of a section of the east wall of trench $D$ " $T$ " J III. The red lines mark small conjugate thrust faults in the hanging wall near the top of the scarp. The steeply dipping beds marked by the light green, blue, and orange flagging are in the detached noses of overturned fault propagation folds. At the base of the trench, the red-flagged contact marks the top of a shear zone that constitutes the principal thrust fault. 


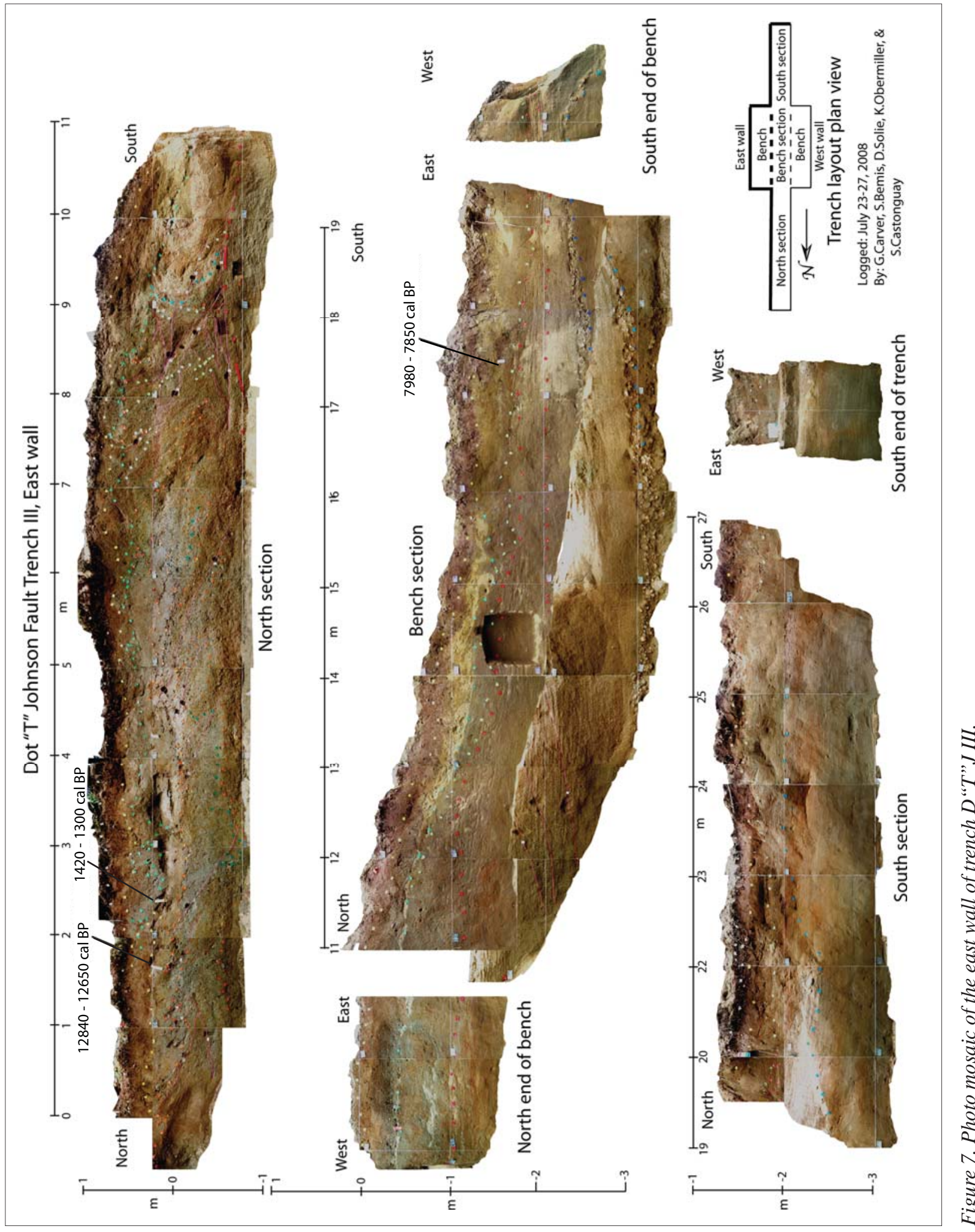




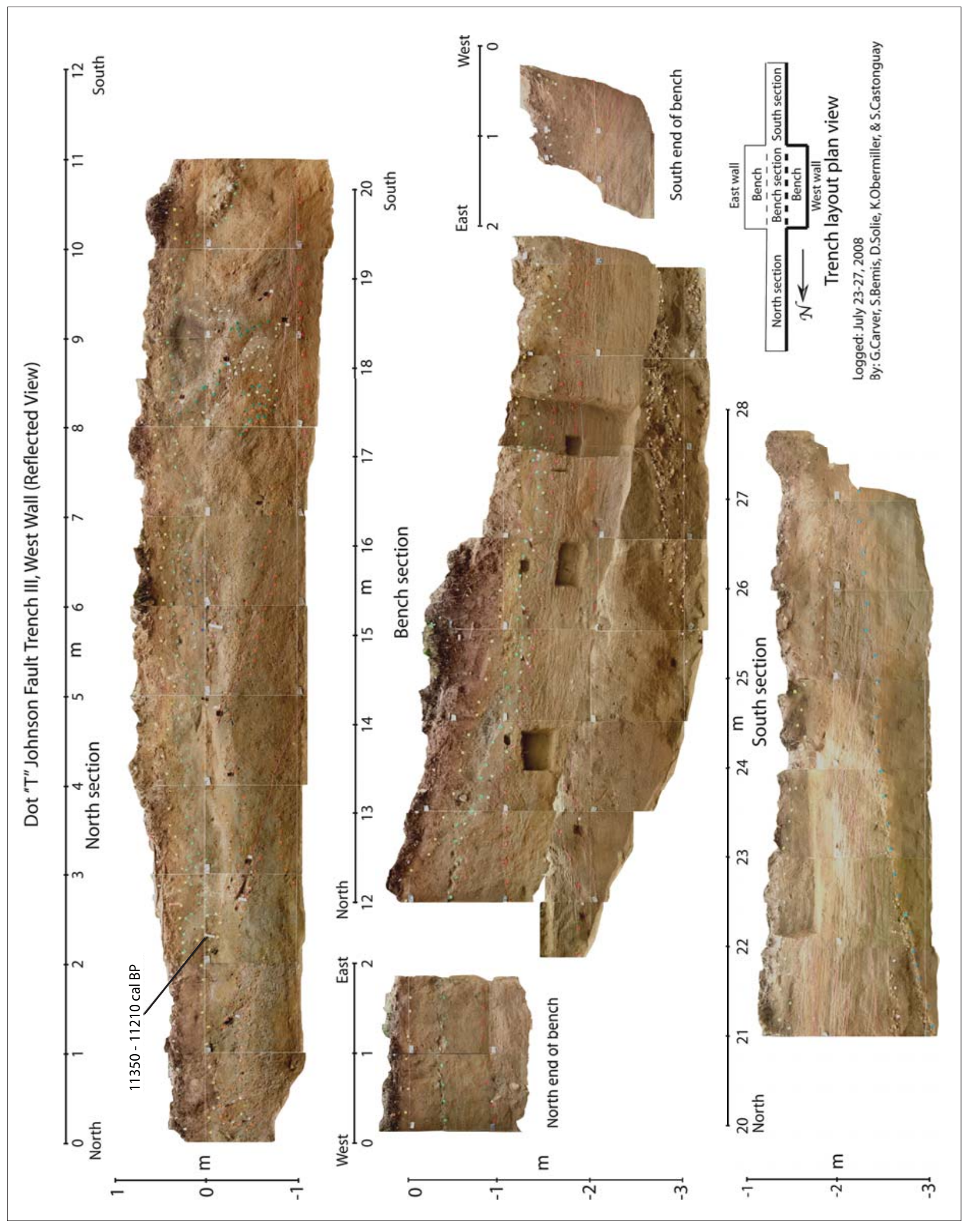

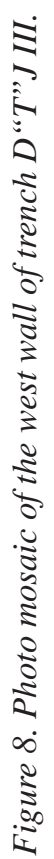




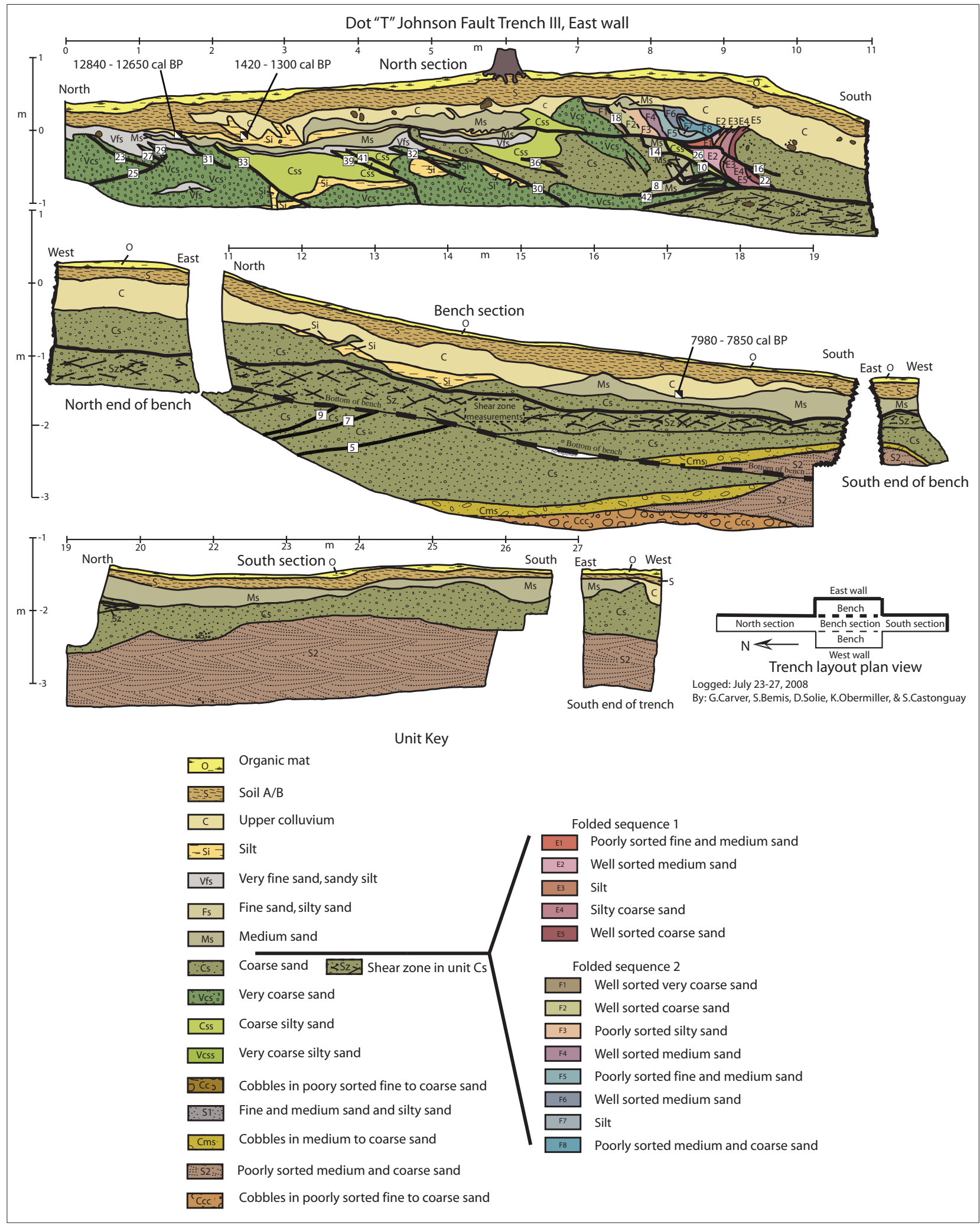

Figure 9. Trench log of the east wall of the D“T”J III trench. 


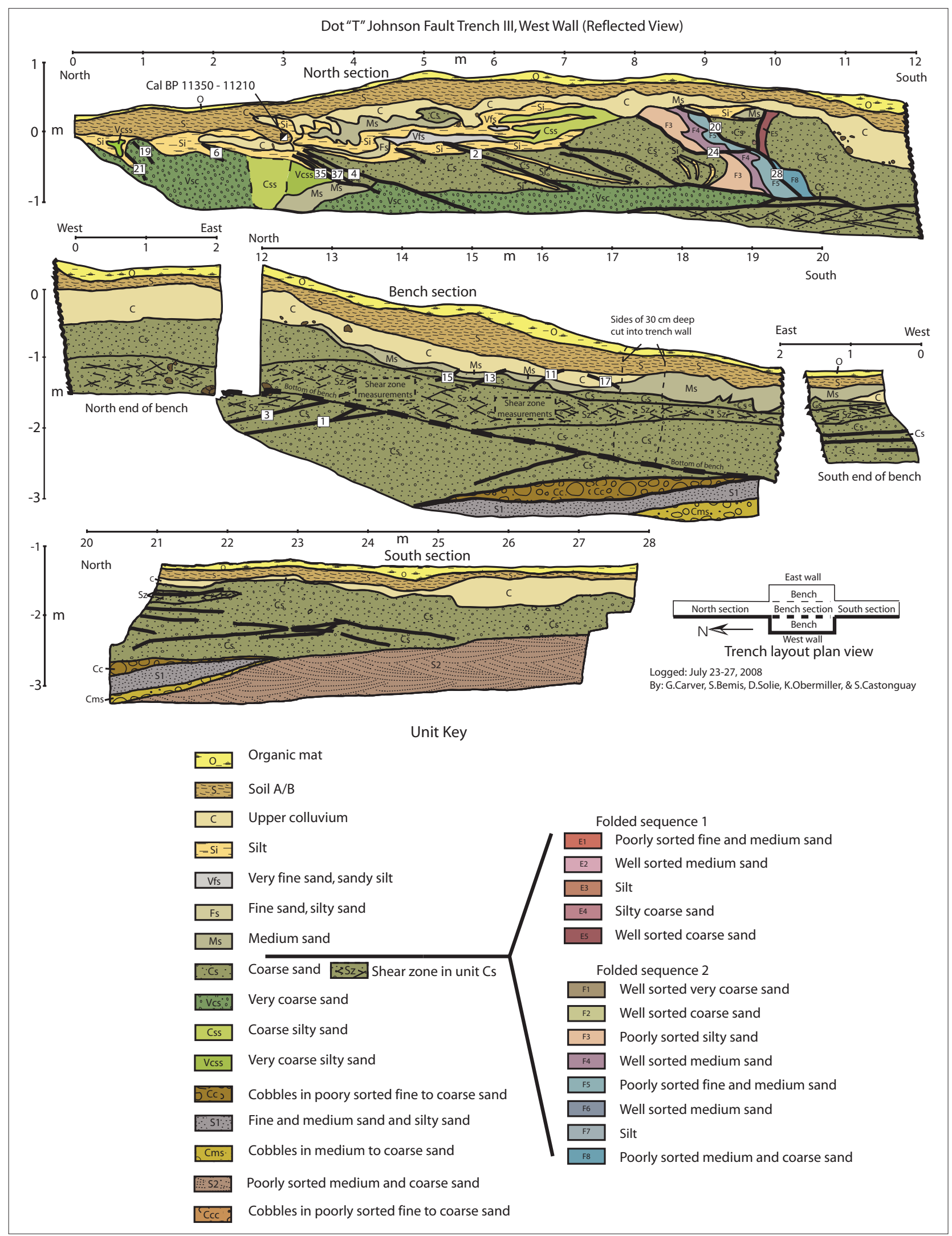

Figure 10. Trench log of the west wall of the $D$ " $T$ " J III trench. 


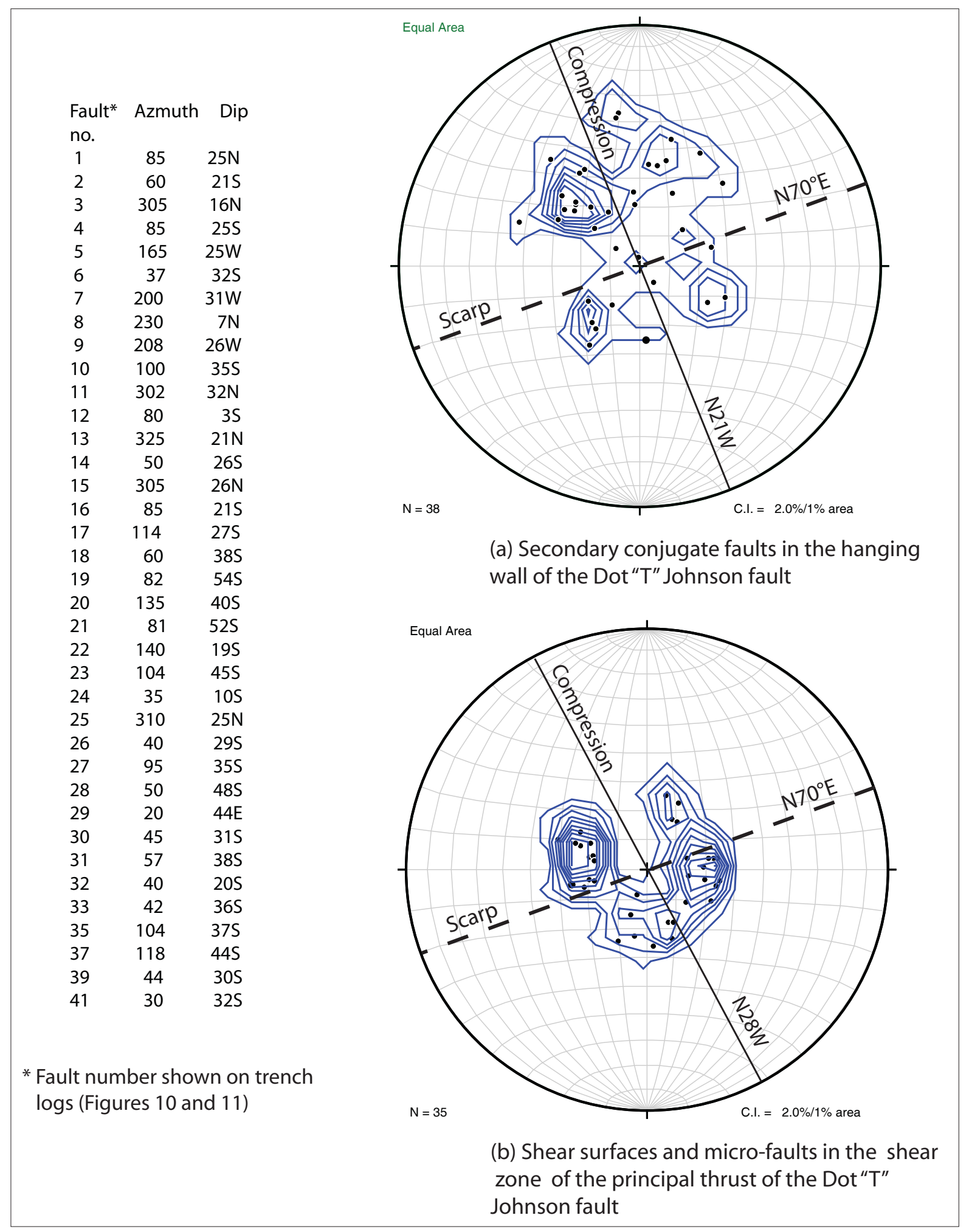

Figure 11. Stereogram plots of poles to planes of secondary conjugate faults in the hanging wall (a) and shears and micro-faults in the principal thrust (b) of the Dot “ $T$ ” Johnson fault measured in trench $D$ “ $T$ ” $J$ III. The stereograms also show the trend of the scarp at the trench site and best fit orientation of the axis of principal compression (sigma 1) from the secondary conjugate faults in the hanging wall and the micro-faults and shears in the principal thrust fault shear zone. 
Multiple episodes of faulting are evident by stratigraphic bracketed upward terminations of secondary thrust faults and faults offsetting faults in the trench. The most recent faulting event is represented by several small faults that cut unit $\mathrm{C}$ and terminate at the base of unit $\mathrm{S}$ at the south end of the benched section in the west wall of the trench (fig. 10). Evidence for this event is limited, possibly because the surface displacement was small at this location and the fault slip was largely accommodated by shear in the underlying shear zone. Alternatively, displacement was predominantly blind and accommodated by folding with little surface fault offset during this event. The event occurred more recently than 7,980-7,850 cal BP.

Several faulting events are represented by the hanging-wall thrusts that offset the base of the upper sequence of fluvial silt and sand (units Ms, Fs, Vfs, and Si) but do not cut unit C. Most of these faults die out down-section or are truncated at internal contacts within the fluvial sequence. The severe internal deformation within these sediments precludes differentiation of individual faulting events. The overprint of cryogenic deformation and liquefaction further complicates the interpretation of paleoseismic events in this part of the trench. These events predate 7,980-7,850 cal BP and may be older than 11,350-11,210 cal BP. Additional earlier paleo-earthquakes are indicated by crosscutting faults within the folded sequences in the fault-bounded fold noses (figs. 9 and 10).

\section{ROBERTSON RIVER STEP-OVER}

The Cathedral Rapids fault and Giant Moletrack anticline represent the principal active range-front structures at the eastern end of the NFFTB (fig. 3). The Robertson River step-over is an approximately $32 \mathrm{~km}$ right step in the Alaska Range foothills, Tanana River valley, and NFFTB between the eastern end of the Dot "T" Johnson fault and western end of the Cathedral Rapids fault (fig. 3). The nature and location of faults or other active structures that connect the Dot "T" Johnson and Cathedral Rapids faults across the step-over have not been identified. One candidate for a connecting fault is the Bear Creek lineament (fig. 12). This north-south-trending lineament is east

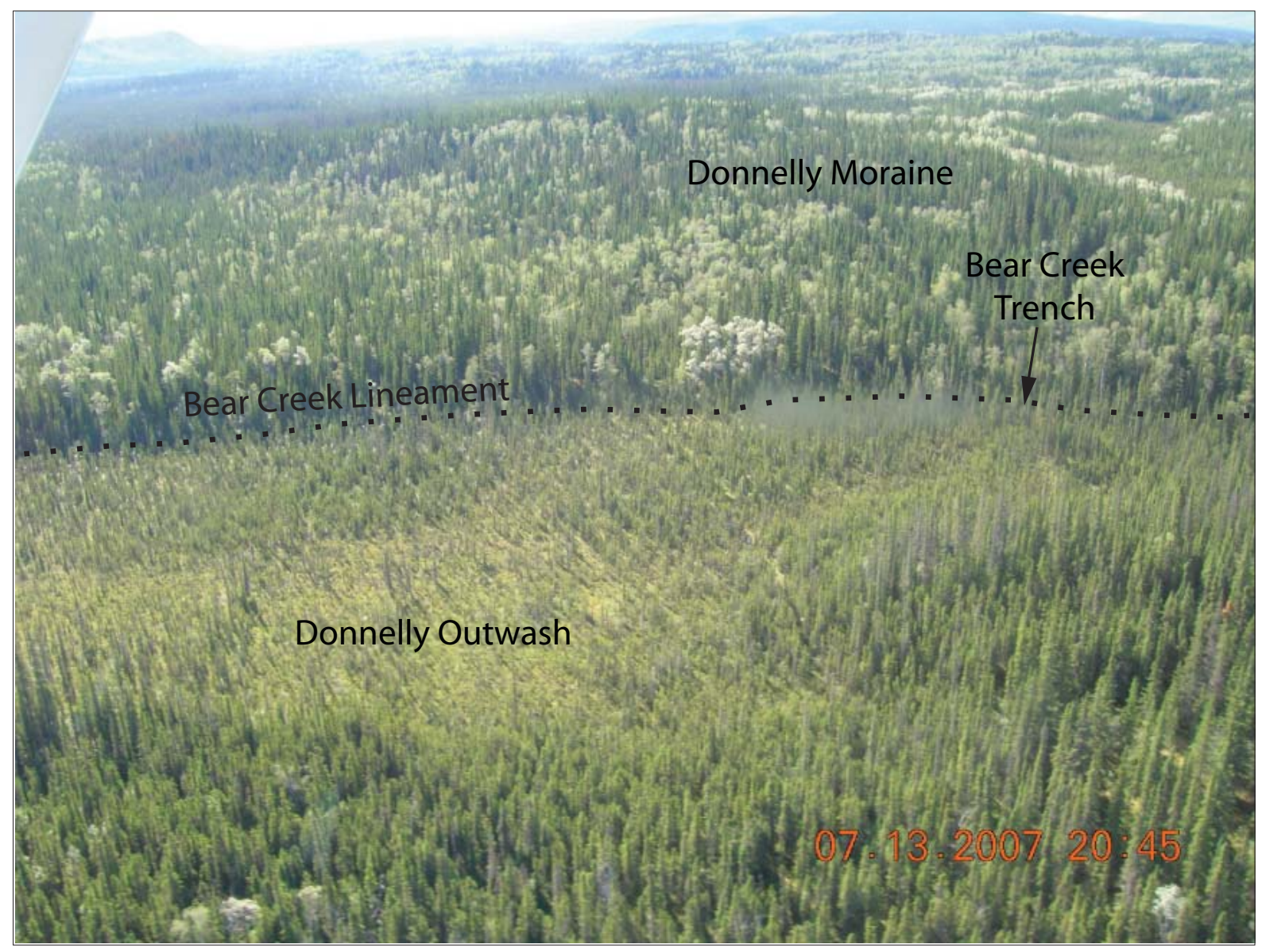

Figure 12. Oblique air photo of the Bear Creek lineament and trench site. View is to the east. 
of and parallel to Bear Creek. A linear west-facing scarp that extends from large Donnelly moraines along the west side of the Robertson River north to the Tanana River floodplain marks the Bear Creek lineament. A dense spruce forest covers the Bear Creek lineament, precluding effective observation from aircraft. Where it crosses the Alaska Highway the scarp has been eroded by Bear Creek. We attempted to trench the scarp at its southern end where it intersects the Robertson River moraines, but were unable to excavate an adequate trench in ice-rich silty sediments to allow determination of the origin of the scarp (fig. 13). Whether the Bear Creek lineament is a fault, and is active, remains indeterminate.

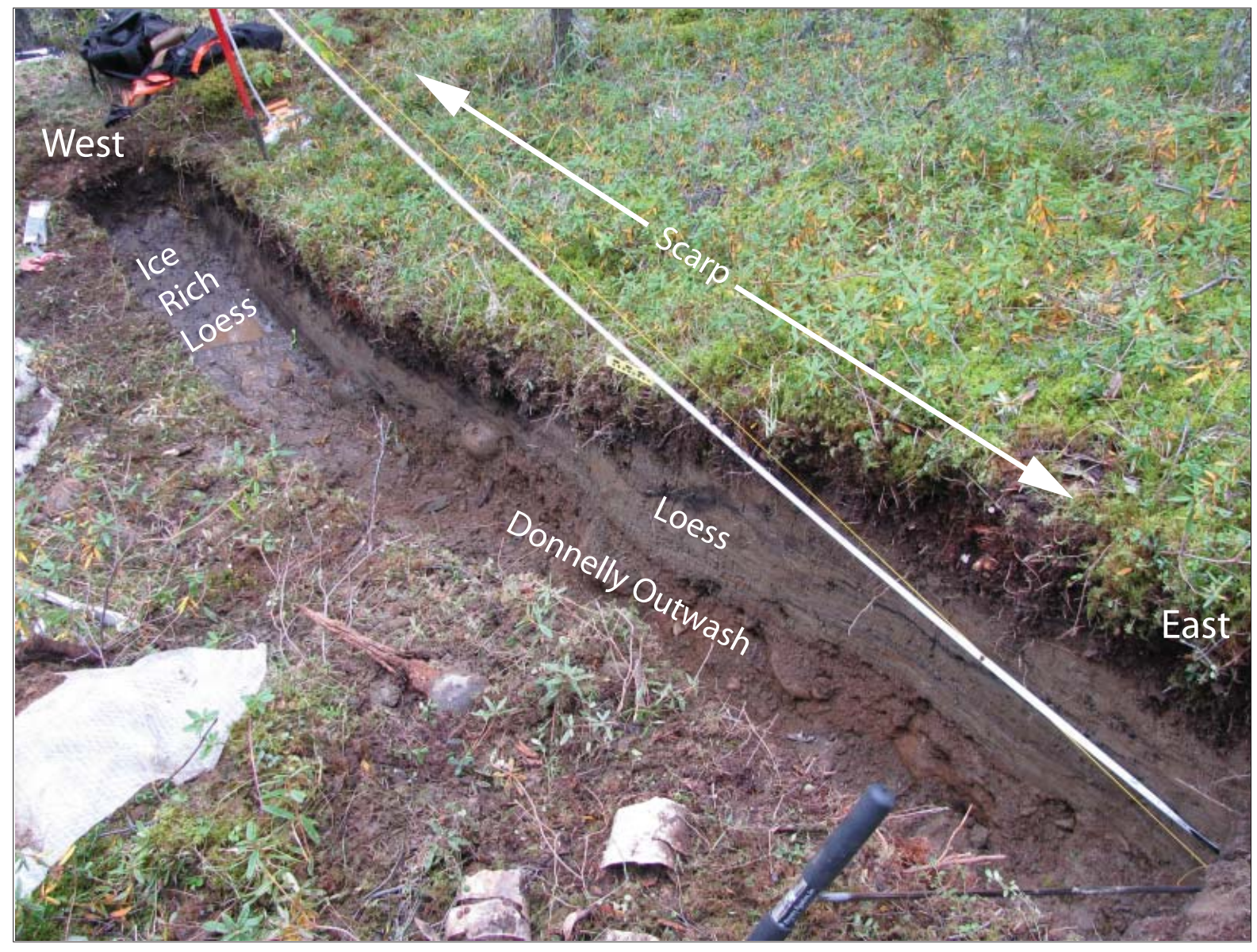

Figure 13. Oblique photo of the Bear Creek trench. No evidence of faulting was observed in the trench, and the contact between the Donnelly outwash and loess was not offset in the upper part of the trench. However, the ice-rich frozen loess prevented excavation of the outwash-loess contact in the lower part of the trench at the base of the scarp where a fault would be expected to daylight. Thus we consider the trench to be inconclusive in demonstrating a lack of faulting.

\section{CATHEDRAL RAPIDS FAULT}

The Cathedral Rapids fault was identified and mapped during the 2008 Alaska Highway corridor studies. The western section of the fault includes two principal imbricate splays, the north and south traces, both sub-parallel south-dipping thrust faults that extend east along the south side of the Tanana River valley for about $21 \mathrm{~km}$ from Sheep Creek to the vicinity of Moon Lake (fig. 14). The fault traverses a 3- to 5-km-wide north-sloping alluvial and colluvial apron at the base of the steep range front. The apron is made up of coalesced alluvial fans, debris flows, landslide deposits, outwash, and Delta and Donnelly age till (Reger and others, 2009). The age of the surface deposits along the range front vary from place to place. The faults form north-facing scarps in these sediments that range from a few to more than $30 \mathrm{~m}$ high, with the higher scarps developed in the older deposits. A third young 
normal fault, the Range Front fault, was mapped along the steep range front south of the Cathedral Rapids fault between Sheep Creek and Moon Lake (fig. 14). This fault offsets late Pleistocene moraines, outwash, alluvium and colluvium (Reger and others, 2009). We interpret this fault as a large bending-moment fault in a fault-bend anticline that forms the range front above the Cathedral Rapids thrust. East of Moon Lake, Cathedral Rapids fault continues for an additional $16 \mathrm{~km}$ as a single sinuous surface trace with an associated large growth anticline. We informally named the anticline the "Giant Moletrack" because its geomorphic form is similar to moletrack-type scarps characteristic of some thrust faults.

East of Moon Lake, Cathedral Rapids fault is sinuous and locally blind. Here its trend varies by about $90^{\circ}$, from nearly north-south to nearly east-west. Fault scarps are small, even in Delta age deposits, but the fold scarp associated with the anticline is up to $50 \mathrm{~m}$ high. Along this section of the fault most of the near surface displacement on the fault is accommodated by growth of the Giant Moletrack anticline.

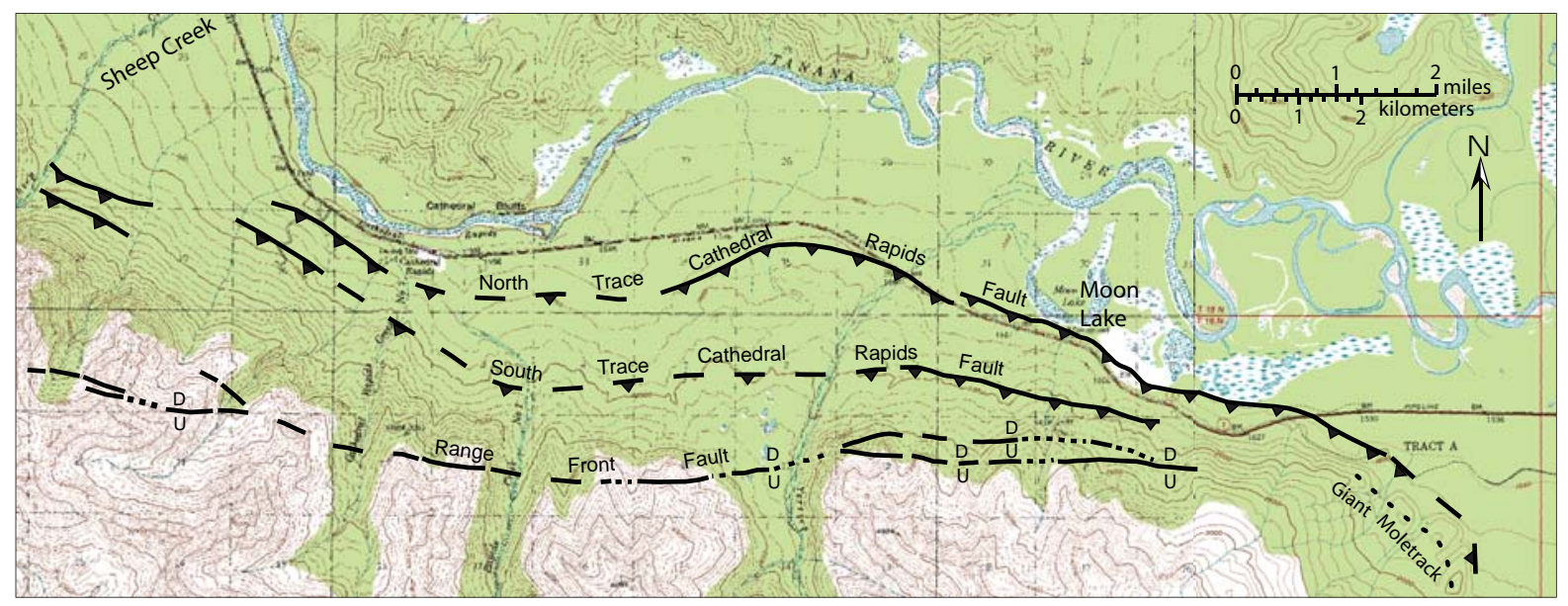

Figure 14. Map of the western part of the Cathedral Rapids fault between Sheep Creek and the west end of the Giant Mole track. This section of the Cathedral Rapids fault includes two imbricate south-dipping thrusts that daylight on the large alluvial apron at the base of the range.

\section{GIANT MOLETRACK}

The 16-km-long section of the Cathedral Rapids fault east of Moon Lake (fig. 15) is marked by variation in its structure and near-surface expression. We term this section of the Cathedral Rapids fault the Giant Moletrack section because its northwestern $8 \mathrm{~km}$ and eastern $4 \mathrm{~km}$ are characterized by a sinuous growth anticlinal ridge up to $70 \mathrm{~m}$ tall (see inset topographic profiles on fig. 16). The anticlinal ridge disappears in the central 4-km-long section of the Giant Moletrack segment where the Cathedral Rapids fault has a linear map trace and small northfacing scarp (fig. 16). The Giant Moletrack section of the Cathedral Rapids fault and associated anticline deform a broad piedmont slope at the toe of the range front composed of coalescing alluvial fans derived from the small drainages in the mountains immediately to the southwest. At their distal end, these coalescing fans grade into the broad, flat Tok Fan (Cararra, 2004; Reger and others, 2009) (fig. 16).

Previous workers interpreted the Giant Moletrack to be a moraine (Foster, 1970), a series of bedrock knobs (Cararra, 2004), or landslide deposits (Carter and Galloway, 1978). However, there is no bedrock exposed in the ridges on the piedmont slope, no evidence of the former presence of a large piedmont glacier along this part of the range front that would be required to emplace a moraine in this position, and no source for landslides large enough to generate the ridges. The compositions of clasts in different parts of the Giant Moletrack deposits correspond directly with the bedrock lithologies immediately upstream and the texture of the deposits matches that of the adjacent piedmont slope deposits. The combination of the shape of the ridge, and the fault scarp adjacent to the ridge's downslope margin, are characteristic of a fault-generated fold. That the fault is parallel to the sinuous ridge indicates they are genetically related. The location of the ridge and fault scarp on the piedmont slope well above the valley floor rules out an erosional origin from the glacial outburst floods that flowed down the Tanana River during the LGM (Reger and others, 2009). Finally, the small streams that head in the range to the south flow across the piedmont slope and through the ridge in deeply incised canyons, evidence that the ridge postdates the development of the local drainage pattern. 


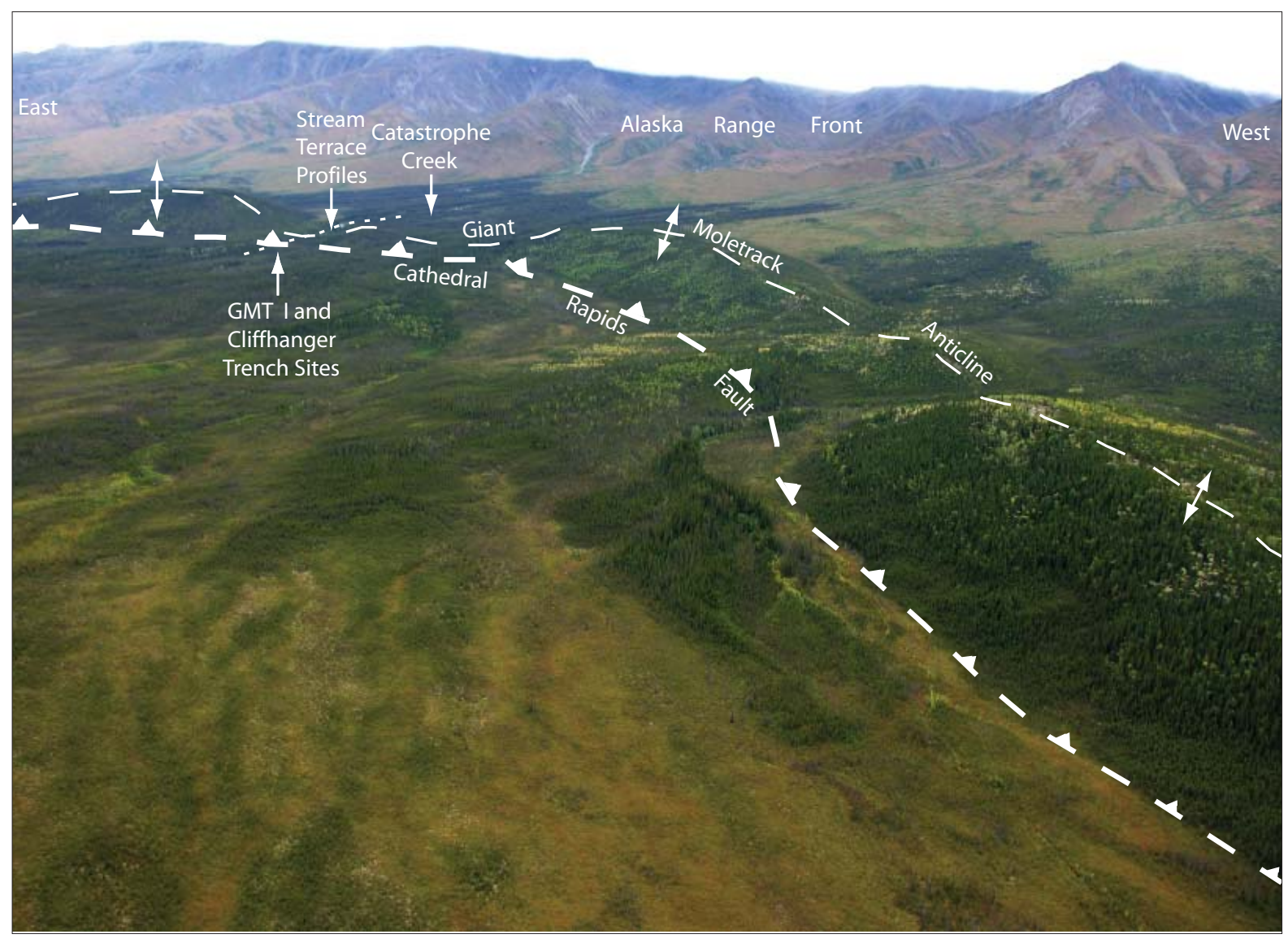

Figure 15. Oblique aerial view looking to the southeast along the central section of the Cathedral Rapids fault and western segment of the Giant Moletrack anticline ridge. The location of the measured stream terrace profiles along Catastrophe Creek and sites of the Cliffhanger and GMT I trenches are shown in the upper left part of the photo.

To test whether the Giant Moletrack anticline and scarp are active fault-related features, we undertook studies along a drainage incised across the ridge we have informally termed "Catastrophe Creek" (fig. 16). We selected Catastrophe Creek for these detailed investigations following helicopter reconnaissance that revealed the presence and excellent preservation of several fluvial terraces along the creek, the visually obvious folding of one of these terraces, and actively raveling exposures of the alluvial deposits in the canyon walls where the creek cut through the anticline. Two investigative approaches were pursued: (1) paleoseismic trenches were excavated across the main fault scarp and secondary grabens, interpreted to be the surface expression of a bending-moment fault at the crest of the anticline, and (2) differential GPS surveys of longitudinal topographic profiles were measured across the anticline and fault in the modern stream channel and on several nested terraces in the stream valley (fig. 17). We also mapped the terraces, faults, associated landforms, and late Quaternary geology in the vicinity of the terrace surveys and trenches (fig. 18).

\section{TERRACE PROFILES}

Antecedent streams have incised through the Giant Moletrack anticline, which through progressive uplift, has locally created abandoned fluvial terraces above the modern stream level. Our investigation identified six raised terraces along Catastrophe Creek. Terraces T1, T2a and b, and T4 (T1 is youngest, with the rest sequentially older) have distinct risers and generally well preserved terrace treads. Two poorly preserved terraces, T3 and T5, occur as distinct landforms, but have experienced significant erosion of the terrace treads and were not assessed in detail. Terrace T1 is characterized by an irregular, bouldery surface with the incipient development of a thin organic mat. This terrace is generally $1-2 \mathrm{~m}$ above the modern streambed and appears to continue to receive overbank deposits during flood flows in Catastrophe Creek. A boreal forest floor dominated by sphagnum mosses and prickly rose 
beneath a dense stand of large, first-generation white spruce trees mantles terraces T2a and T2b. We saw only one relatively fresh stump of a large white spruce on T2b. Cores taken with an increment bore from four of the oldest living white spruce trees were examined using a binocular microscope and had 180, 185, 195, and 197 annual rings. Assuming a short ecesis period for the spruce, the tree rings indicate an age for the terrace of a few hundred years. T4 is the highest well-defined terrace and is preserved continuously (except where it is crossed by one small, incised drainage) across the Giant Moletrack anticlinal ridge. The surface of this terrace is covered with a thick sphagnum mat with abundant low shrubs and black spruce trees.

We collected differential GPS data to construct topographic profiles of the modern Catastrophe Creek thalweg and terrace treads on T2a, T2b, and T4 across the anticlinal ridge. These profiles, shown in figure 17, illustrate the progressive uplift and deformation of the terrace surfaces relative to the Catastrophe Creek channel profile. Terraces T2a and T2b are composed of terrace surfaces vertically separated by a few meters and could only be traced across part of the anticline. The profile of T2a is parallel to the present stream channel, but the northern end of terrace T2b is slightly higher relative to T2a and the stream channel and appears to show relatively recent growth of the fold (fig. 17). Terrace T4 is significantly tilted to the south (upstream) and elevated where it crosses the anticline.

Two segments of T4, one upslope of the anticline and the other across the anticline, were fit by linear regressions to distinguish planar panels that are separated by narrow hinges (fig. 17). The upstream segment of T4 is nearly parallel to Catastrophe Creek and thus has likely uplifted monotonically over a planar thrust fault segment

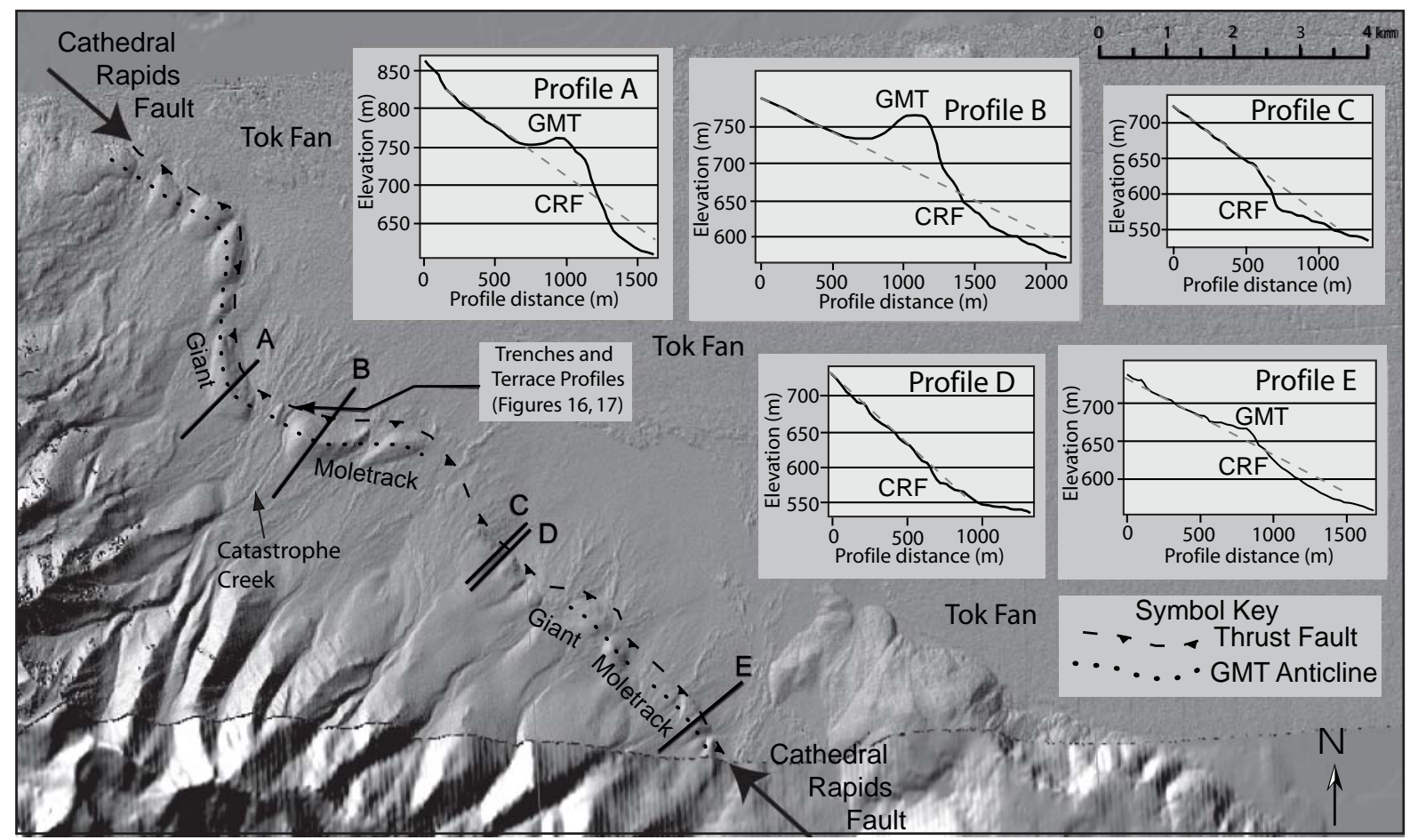

Figure 16. Shaded-relief digital elevation model (DEM) view of the Giant Moletrack and adjacent Cathedral Rapids fault scarp. A 5-m-resolution AirSAR DEM covers the area of the Giant Moletrack anticline and adjacent Cathedral Rapids fault scarp. This DEM is superimposed on the USGS National Elevation Dataset DEM with 30-m resolution to show the relief of the adjacent areas south of the coverage of the AirSAR. The sinuous Cathedral Rapids fault scarp (dashed thrust fault symbol) and Giant Moletrack anticline axis (dotted line) occur outboard of the range front on a wide piedmont apron of coalescing alluvial fans where small streams emanating from the mountains cross the piedmont apron. Profiles A-E (labeled solid lines on the image and solid lines on the inset profile diagrams) were measured using the AirSAR digital data across the anticline and fault scarp. The anticline ridge is labeled GMT and the Cathedral Rapids fault is labeled CRF on the profiles. The gray dashed lines on the profile diagrams illustrate the minimum vertical offset of Quaternary alluvial deposits across the fault. The ages of the alluvial surfaces that these profiles transect are unknown, but the surfaces downhill (on the footwall) of the scarp are younger due to alluvial deposits from drainages that have incised through the scarp. Note the anticline does not appear on profiles $C$ and D. 
at depth. The downstream segment of T4 is distinctly back-tilted relative to the stream gradient, indicating a change in fault geometry (a listric ramp) as the fault plane approaches the surface. Amos and others (2007) observed similar terrace geometry on active thrust faults in New Zealand, and demonstrated that the back tilting of terraces could most easily be explained by a listric fault in the subsurface. To the north, beyond the back-tilted segment of T4, the terrace surface gradually steepens to where it abruptly drops off at the north-facing forelimb and scarp (fig. 17). This terrace does not appear at the surface downslope of the fault scarp due to presence of younger alluvial fan deposits covering the footwall. Slope processes and lateral incision during alluvial fan formation has locally modified the steep face of the anticline forelimb and fault scarp, but it is clear that the T4 terrace surface is dramatically folded to form this scarp face.

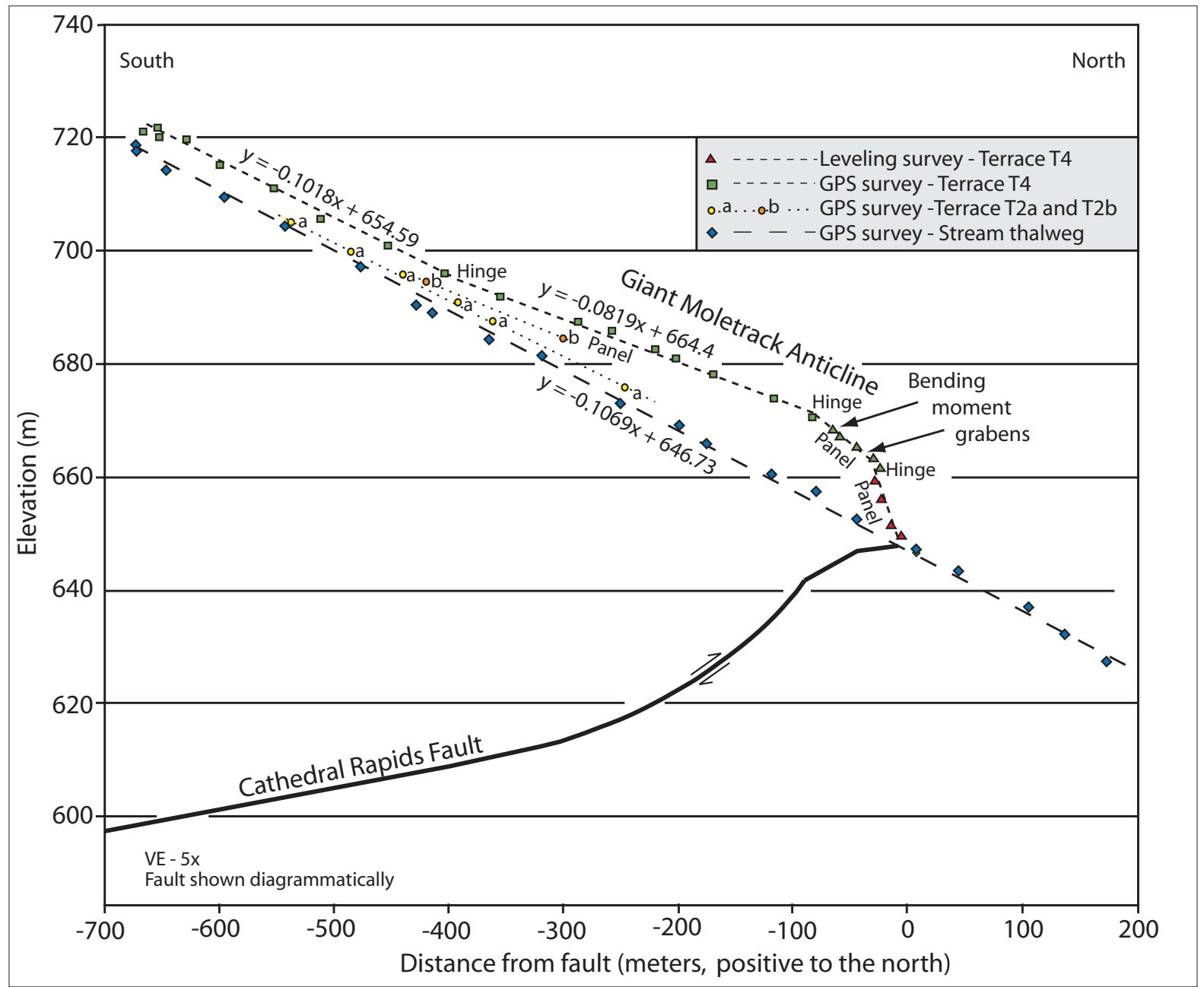

Figure 17. Differential GPS topographic profiles of stream terraces across the Giant Moletrack anticline and Cathedral Rapids fault scarp. Stream survey points (green diamonds) were collected along the thalweg of the streambed of the ephemeral, informally named Catastrophe Creek. The stream thalweg profile is shown with the long-dashed line. Terraces T2a and T2b are discontinuous, low terraces with $<2$ m elevation differences (yellow circles and dotted lines). Terrace T4 (green squares and short-dashed line) is a distinct, continuous terrace that is easily followed for its entire length. Equations are linear regressions for the two long, nearplanar segments of T4 and the thalweg profile of Catastrophe Creek. The red triangles were obtained from a leveling survey across the forelimb panels of folded Terrace T4. The back tilting of the central panel of Terrace T4 relative to the stream profile likely results from a listric fault in the near surface (Amos and others, 2007). Location and dip of the fault in the subsurface is shown diagrammatically. 


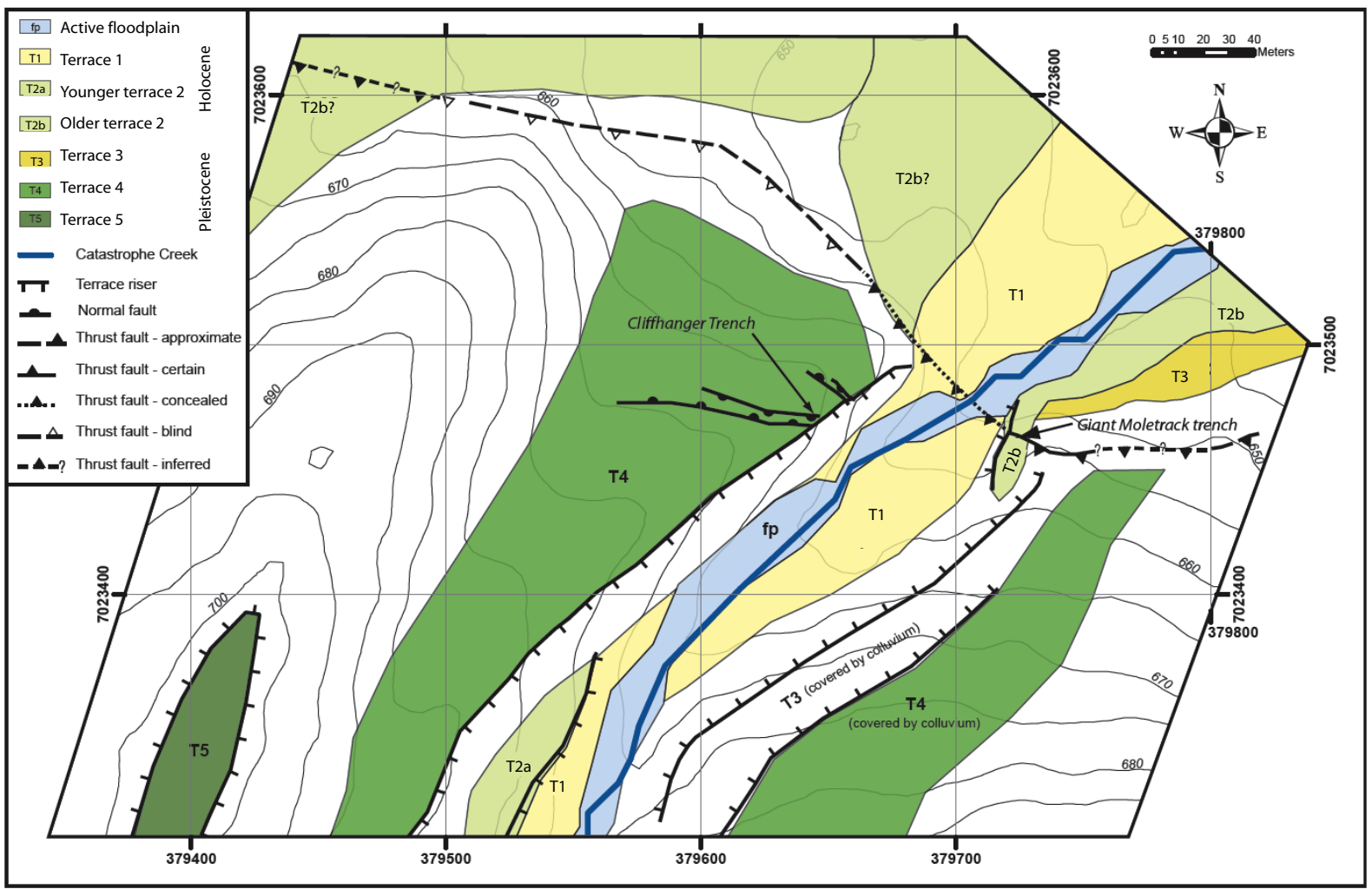

Figure 18. Geomorphic map of the informally named Catastrophe Creek field site on the Giant Moletrack anticline and Cathedral Rapids fault scarp. Catastrophe Creek has incised a small canyon through the anticline formed by progressive uplift of the hanging-wall of the Cathedral Rapids fault and growth of the Giant Moletrack anticline. Several fluvial terraces are preserved in this canyon and record progressive uplift of the anticline. The most prominent of these terraces are mapped here, with additional uncorrelated, discontinuous terrace remnants present but not shown. Contour interval $=5 \mathrm{~m}$.

\section{CLIFFHANGER TRENCH}

Above the fault scarp face on T4, near the crest of the fault-generated fold (location shown on figs. 17 and 18), are two east-west-trending shallow $(<1 \mathrm{~m})$ troughs that parallel the fold crest. These troughs are exposed in cross-section in the actively raveling Catastrophe Creek canyon wall cut into the T4 terrace riser (fig. 19). The exposure shows that these troughs are small grabens that are filled with faulted fine-grained sediments, buried soils, and colluvium (fig. 20). We interpret these structures as bending-moment grabens that accommodate extension at hinges in the crest of the anticline during folding events associated with displacement on the underlying thrust fault (Carver and McCalpin, 2009; Carver and McCalpin, 1996). Thus, these grabens contain evidence of coseismic deformation and therefore a record of paleo-earthquakes on the underlying fault.

To interpret this paleo-earthquake record, we cleaned off a 7-m-long by 1.5-m-deep exposure on the face of the cliff across the southern, more topographically distinct graben (fig. 20). An interpreted photo mosaic of this exposure is shown in figure 21 and a log of the graben cross-section in figure 22. The graben structure is clearly defined by steeply dipping normal faults that separate the coarse-grained alluvial and colluvial deposits of terrace T4 from the fine-grained colluvium and loess that fills the graben. We did not expose the bottom of the graben.

Within the graben we tentatively identified at least five discrete faulting events. The oldest offsets units Cpsc, a graben-filling colluvium, T, a very fine silty volcanic ash, and Pss, a poorly sorted, pebbly, silty, sandy colluvium on faults 4 and 7 (figs. 21 and 22). Units Ps, Cps, and L1 cap faults 4 and 7. The age and origin of the ash (unit T) is unknown. The timing of this faulting event is older than $12,330-11,630$ cal BP from a charcoal sample collected in unit Cfss, about 0.5 m above unit T. Since units Cpsc, T, and Pss are preserved in a pre-existing graben, this faulting event is not the first associated with the graben's formation; the graben was initially generated during one or more earlier episodes of coseismic folding of the Giant Moletrack anticline and associated bending-moment faulting. 


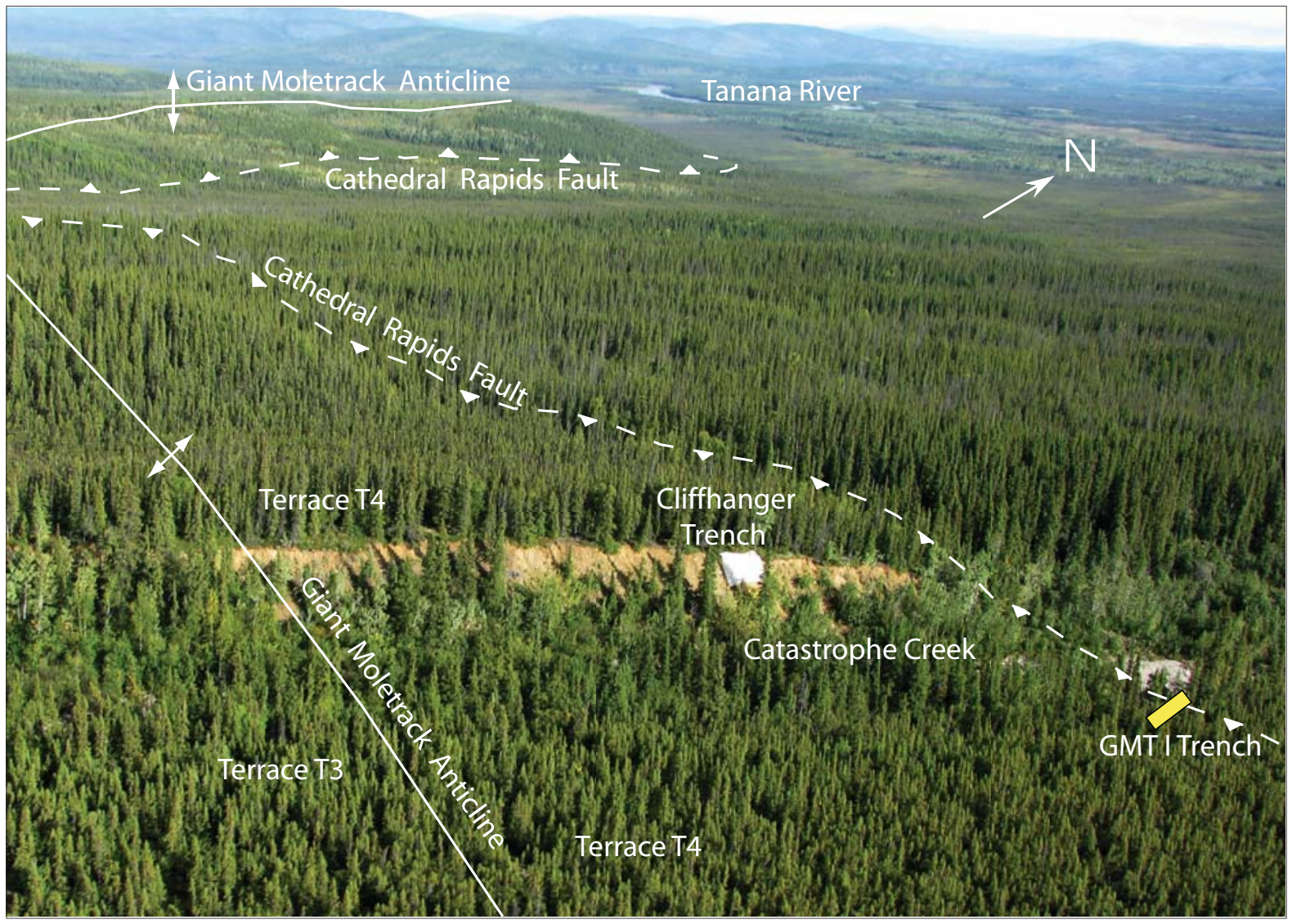

Figure 19. Oblique photo (view to the northwest) of the Catastrophe Creek study site showing the Giant Moletrack anticline, Cathedral Rapids fault, Catastrophe Creek terraces and Cliffhanger and GMT I trench sites.

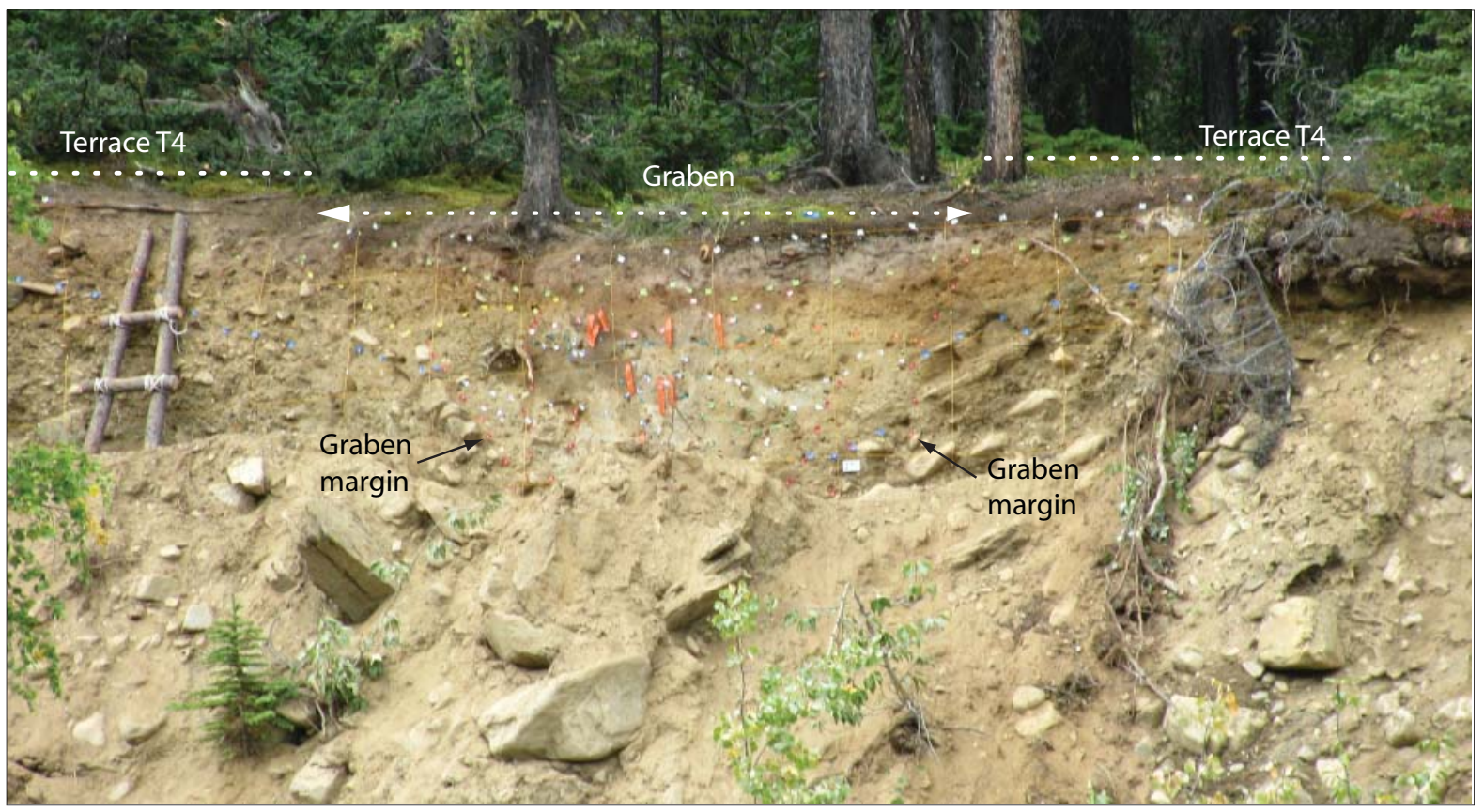

Figure 20. Photo of the Cliffhanger trench exposure. The trench exposure provides a cross section through one of two grabens on bending moment faults in the crest of the Giant Moletrack anticline. 


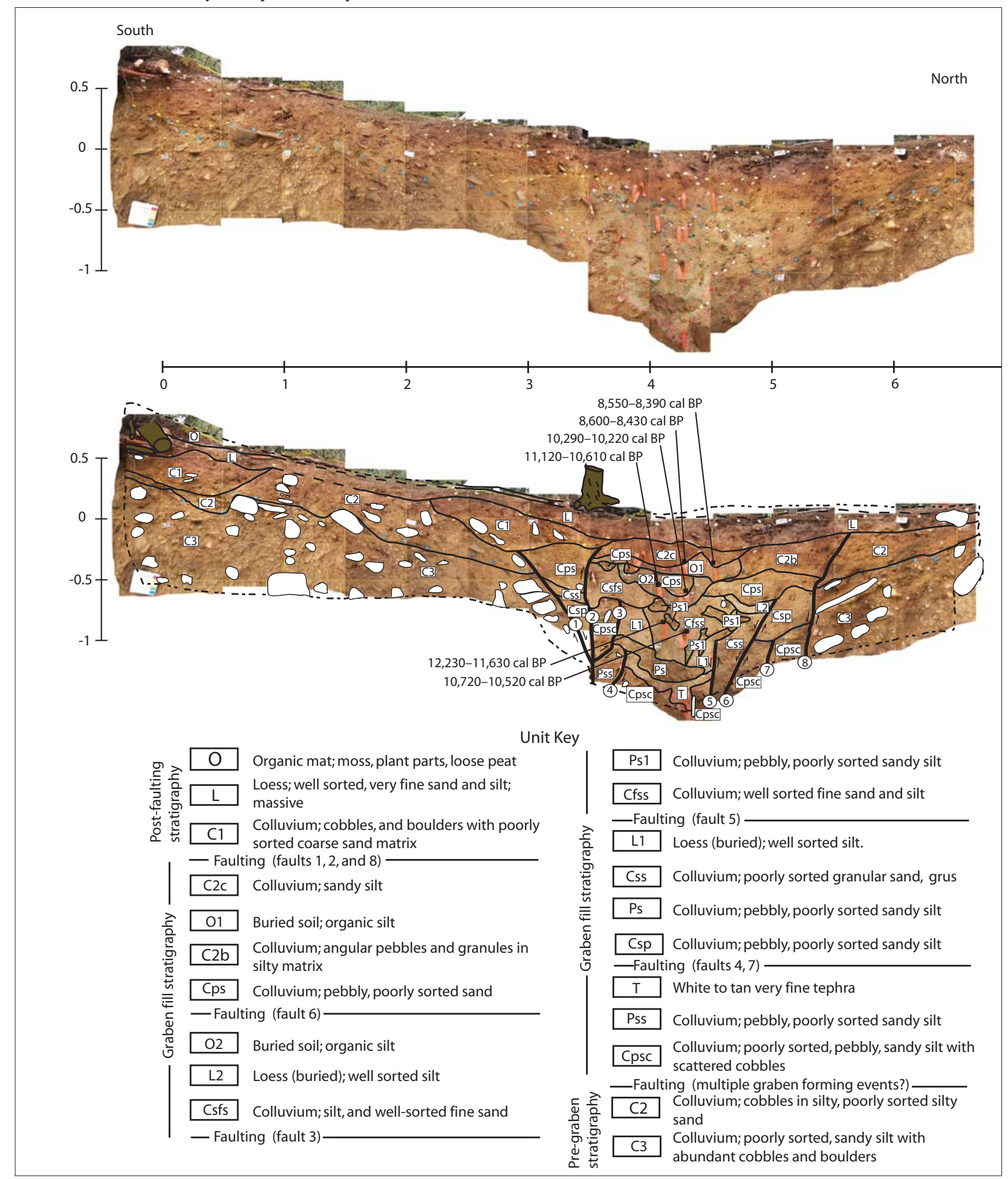

Figure 21. Photo mosaics of the Cliffhanger trench exposure without interpretation (above) and with interpretation (below). 
Fault 5 (figs. 21 and 22) offsets units Li and Ps and is truncated by unit Cfss, documenting a second episode of faulting in the graben. The age of the charcoal sample from unit Cfss also provides a maximum age for this event. A third faulting event is interpreted from units L1 and Cpsc that are offset by fault 3. Unit Csfs caps fault 3. The age of this faulting event is bracketed by ${ }^{14} \mathrm{C}$ ages on charcoal from unit Cfss of 10,720-10,520 cal BP and from unit Cps of 10,290-10,220 cal BP (figs. 21 and 22). A fourth faulting event offsets units Csp and L2 on fault 6 (figs. 21 and 22). Unit Cps caps fault 6. Its age is also constrained by a maximum age from unit Cfss of 10,720-10,520 cal BP and a minimum age from the base of unit Cps of 10,290-10,220 cal BP.

The most recent faults in the graben (1, 2, and 8) offset colluvial units 2C, C2b and C2c. Unit C2c contains detrital charcoal pieces near its base that date to 8,550-8,390 cal BP and 8,600-8,430 cal BP. These provide maximum limiting ages for the most recent faulting in the graben. The minimum age for the most recent faulting in the

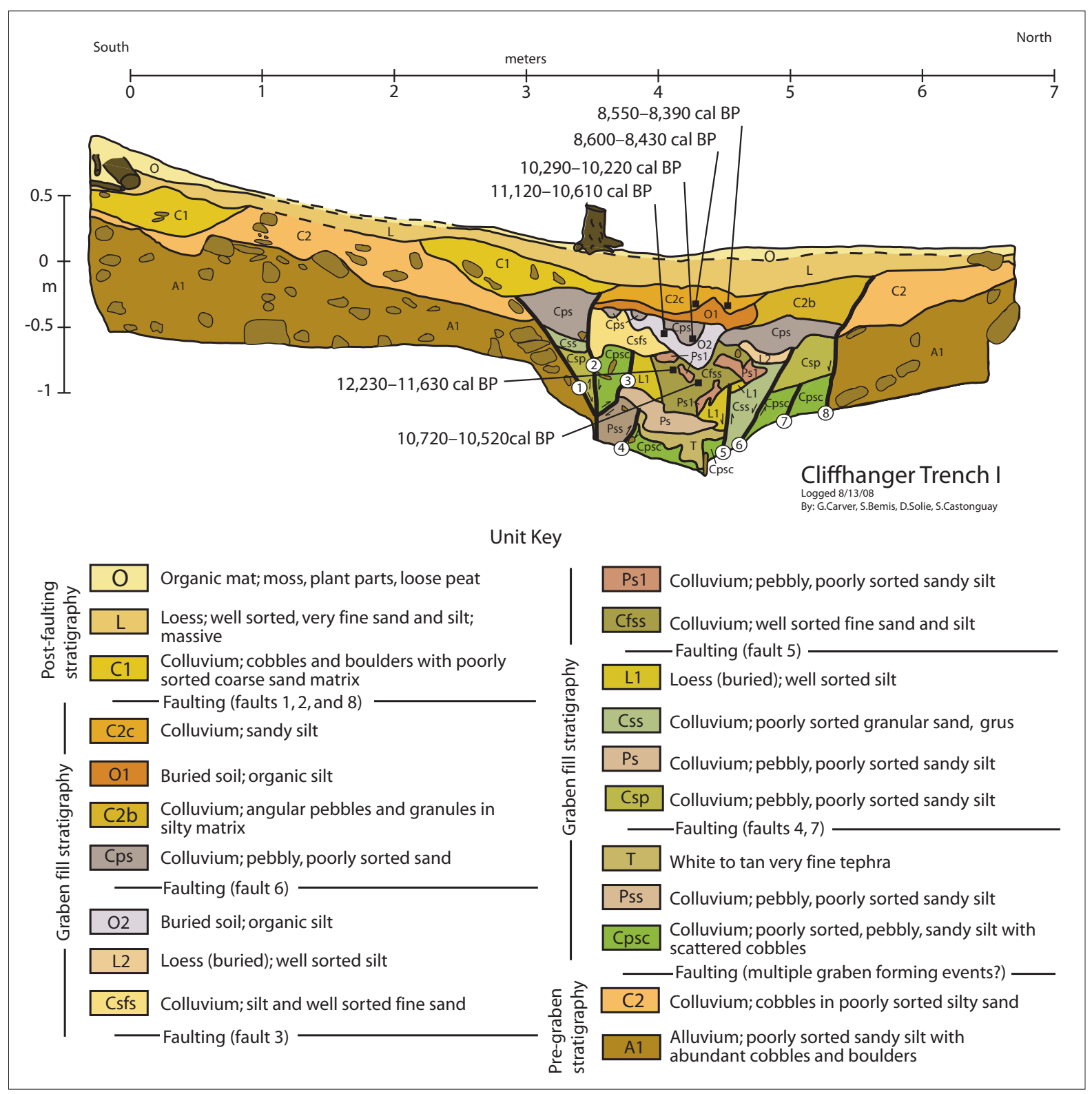

Figure 22. Log of the Cliffhanger trench exposure. At least five paleo-earthquakes are interpreted from upward terminations of faults in the graben fill sediments. 
graben is unconstrained. Unit C2c is partially overlain by unit C1, which caps fault 1, and the entire exposure is capped by an unfaulted loess layer (unit L).

Since bending-moment grabens are secondary fault features formed at hinges between panels of fault-generated folds in the hanging walls of thrusts and migrate away from the hinge as displacement accrues on the underlying thrust, they become inactive when they are no longer at or near the hinge. The graben we studied is no longer at the hinge that likely generated it. Thus it is probable that additional slip events have occurred on the underlying fault since the graben was active.

\section{GIANT MOLETRACK TRENCH}

On the east side of Catastrophe Creek, opposite the Cliffhanger trench, we identified an 2-m-high gently sloping scarp offsetting a young terrace, possibly correlative with terrace T2b. This scarp aligns with an abrupt slope break immediately to the east that we interpret as the fold scarp of the Cathedral Rapids fault (fig. 19). A steeper, 1-m-high facet is present along sections of the fold scarp including the section where it offsets the Catastrophe Creek terrace. The steeper facet is not present on the west side terrace. We excavated a 7-m-long and approximately 1-m-deep trench (trench GMT I) across the scarp where the steeper facet ends (figs. 23 and 24).

In general, the stratigraphy exposed in the trench is characterized, from top to bottom, by: (1) a $20-30 \mathrm{~cm}$ section of interbedded organic mats and well sorted fluvial sands (units $\mathrm{O}, \mathrm{S} 1, \mathrm{O} 1, \mathrm{~S} 2$, and O2); (2) 40-70-cm-thick stratified colluvial deposits, with local fluvial sand horizons (units C1, C1a, and C1b) containing discontinuous thin streaks of very-fine-grained black organics and charcoal (white flagging and white dashed lines on the trench wall photo shown in fig. 25 and black dashed lines on the trench log shown in fig. 26); and (3) frozen, boulder-rich colluvial units at the bottom of the trench (units C2 and C3). These frozen sediments were the lower limit of our excavation. This stratigraphy is for the most part parallel bedded and gently inclined beneath the fold scarp at the same angle as the ground surface. A small pit excavated into the undeformed terrace surface above the scarp encountered the same stratigraphy as in the trench. Bedding in the pit is horizontal (fig. 26). We interpret the gently sloping scarp to be a fold scarp at the tip of the Cathedral Rapids fault.

There are distinct differences in the scarp morphology between the two trench walls,

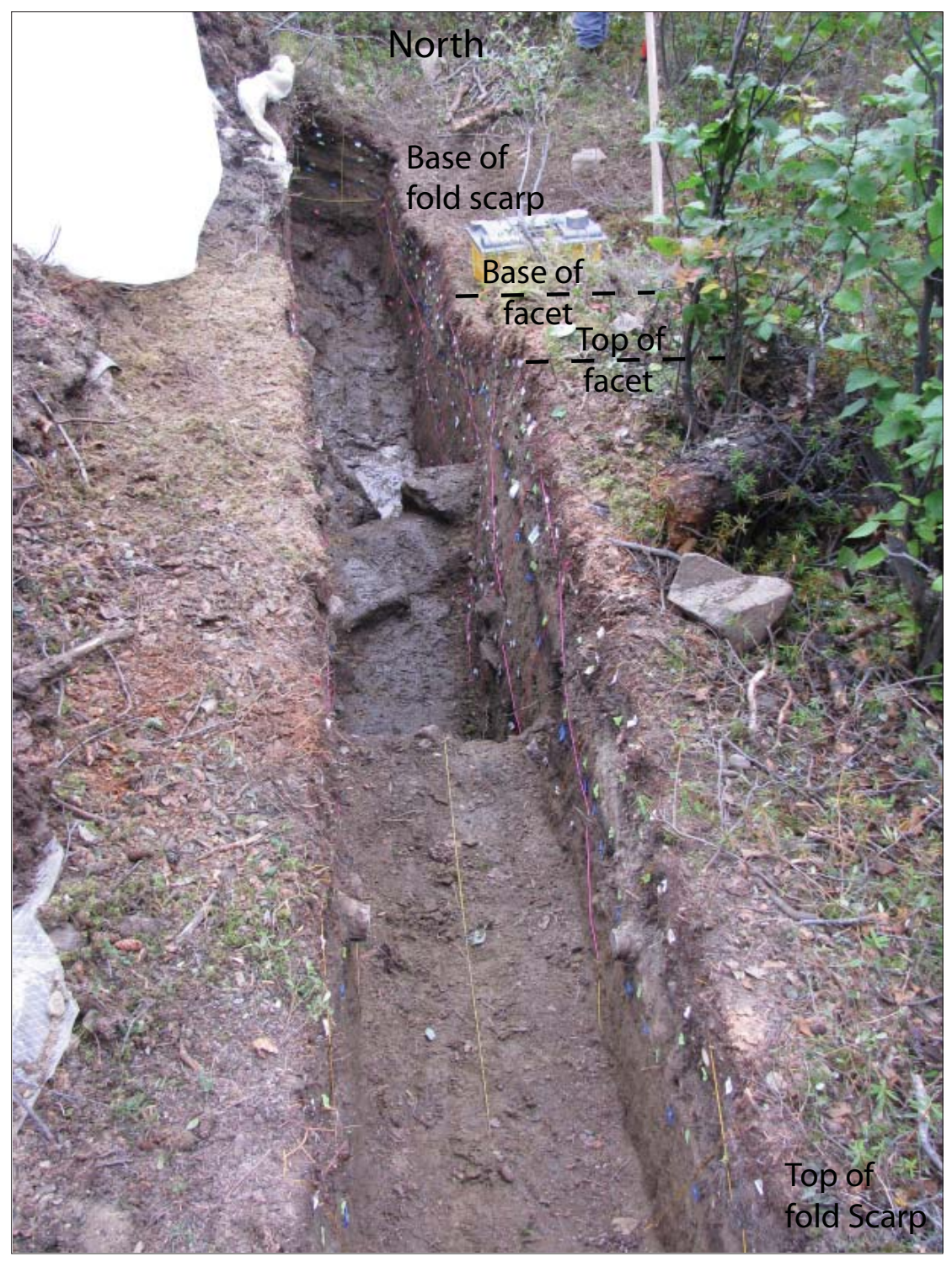

Figure 23. Photo of trench GMT I viewed to the north from the top of the scarp on terrace $T 2 b$. 


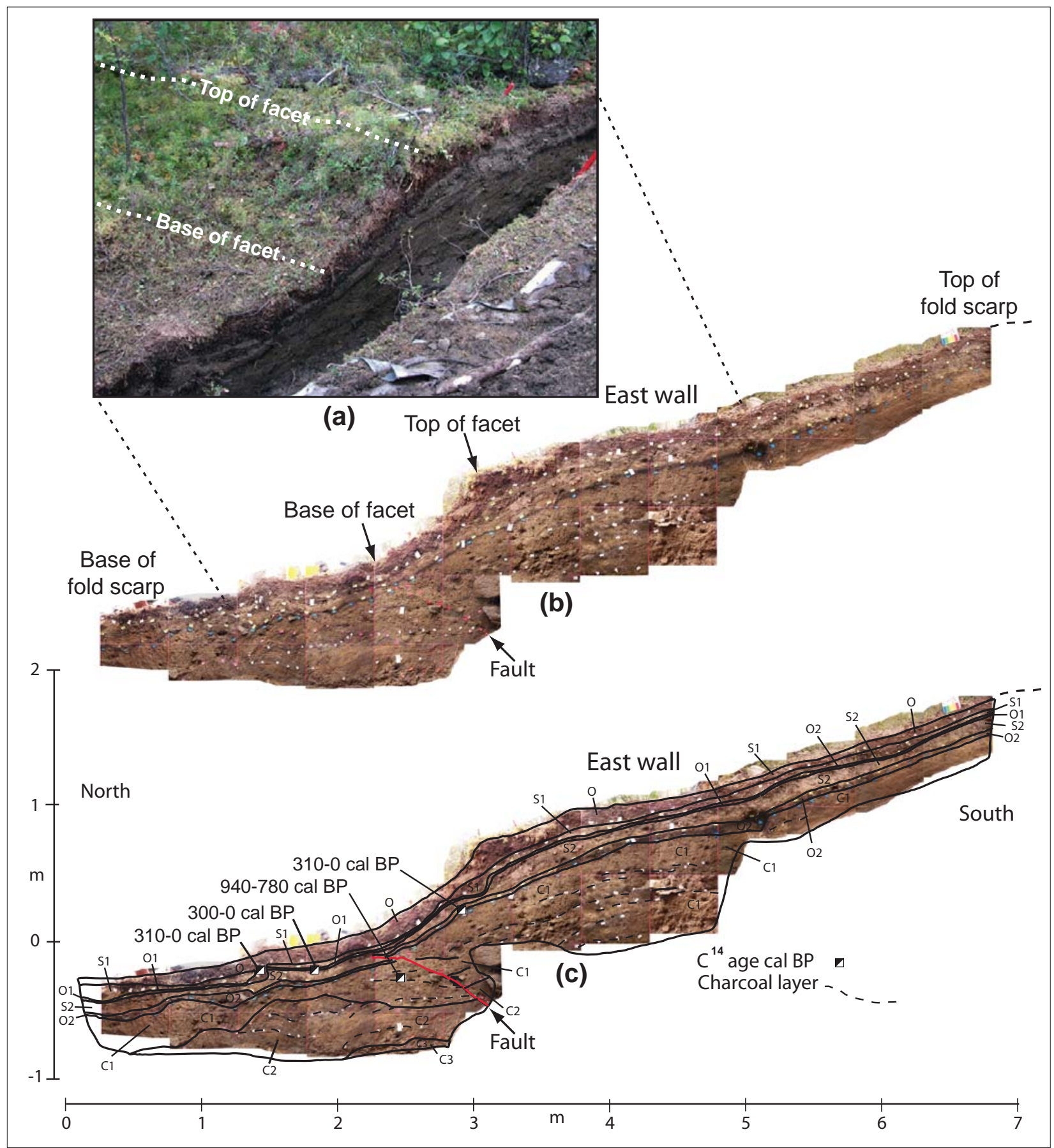

Figure 24. (a) Oblique view of the east wall of trench GMT I showing the steep facet on the fold scarp. (b) Photo mosaic of the east wall of trench GMT I. (c) Interpreted photo mosaic of the east wall of trench GMT I. Unit designations from the trench $\log$ (fig. 26). 
as well as subtle differences between the colluvial sections. The east wall exposed a section across the $~ 1-m$-high steep scarp facet, the most pronounced morphological step in the terrace surface. Underlying this step is a convexup, south-dipping thrust fault trace that offsets the unit C1/C2 contact, buried organic mat O2, and several thin organic/charcoal horizons, all by 10-15 cm (figs. 25 and 26). Looking simply at the fault trace, it would appear that buried organic mat $\mathrm{O} 1$ truncates the fault, suggesting the age of this horizon would provide a minimum limiting age for this faulting event. However, we find it difficult to envision a scenario in which the thin, well-sorted fluvial sands S1 and S2 could be deposited and preserved continuously across the scarp and steep facet, as seen in the east wall of the trench.

Our favored interpretation is that the sands were deposited during overbank floods of the creek and covered with an organic mat before the terrace was deformed. The 2-m-high gentle scarp represents a fold scarp generated by a single episode of recent displacement on a largely blind south-dipping thrust with most of the displacement accommodated by folding at the surface. Based on the 2-m-high fold scarp and an assumed dip of $30^{\circ}$ for the fault at depth (the dip of the small fault exposed in the trench), geometric relations suggest about $4 \mathrm{~m}$ of dip-slip displacement on the fault at depth. As the fault approached the surface, slip on the fault decreased and warping of the sediments increased, producing the fold scarp. With the small $(10-15 \mathrm{~cm})$ displacement of the fault at the surface, and a strong mechanical contrast between the essentially cohesionless fluvial sand unit S2 and the fibrous, densely rooted overlying organic mats ( $\mathrm{O}$ and $\mathrm{O} 1$ ), we speculate that the surface trace of the fault-exploited unit S2 is a

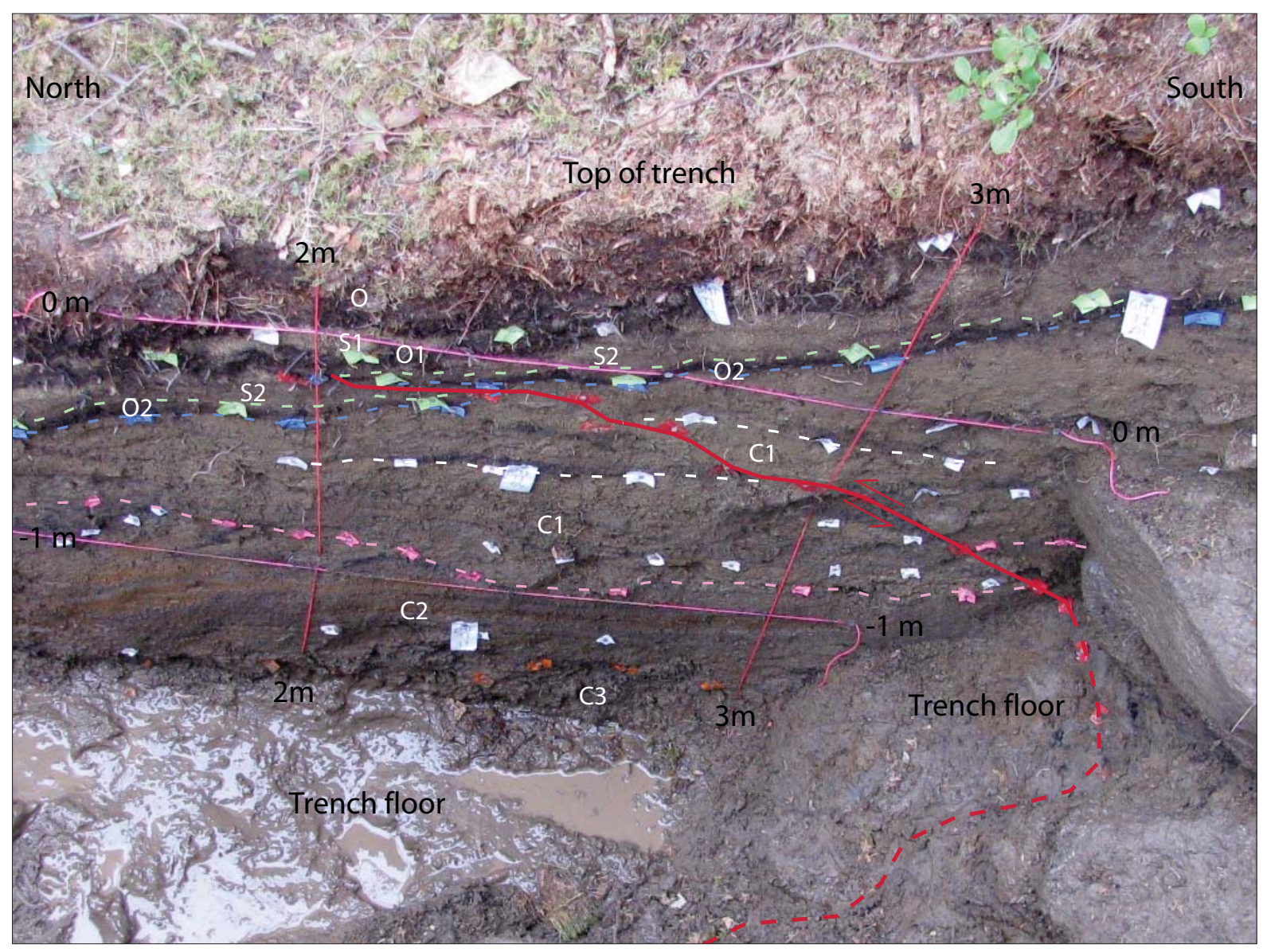

Figure 25. Close-up view of the fault in the east wall of GMT I trench. The light green dashed line marks the base of the lower layer of a well sorted fluvial sand (unit S2). The blue dashed line is the base of a charcoal-rich organic silt (unit O2). The white dashed lines mark thin streaks of fine-grained charcoal and organic material in the colluvium (unit C1). The pink dashed line shows the base of this colluvium. The fault (red line) offsets the charcoal streaks and contacts between the colluviums C2 and C1 and the overlying organic layer O2 and base of the fluvial sand S2. Where the fault crosses the trench floor it is deflected around large boulders on the west side of the trench and is oblique to the orientation of the trench. Unit designations are from the trench $\log$ (fig. 26). 
detachment horizon and translated the overlying units downslope where they formed a secondary small fold (the steep facet) in the larger fold scarp, creating the apparent offset in unit $\mathrm{O} 1$ at the odd-shaped protrusion of modern organic mat $\mathrm{O}$ into the underlying deposits.

In the west wall the fault is less distinct, and where it extends through the lower colluvial units it is about $1.5 \mathrm{~m}$ downslope from its position in the east wall, indicating the strike of the fault is highly oblique to the trench. In the lower colluvial units the fault intersects large boulders that appear to control its location and shape in the trench. The fault tip dies out in the uppermost part of the upper colluvium and does not appear to offset the upper sands and organic layers (fig. 26). We infer that the most recent faulting occurred after deposition of unit S1 and sometime during the formation of unit $\mathrm{O}$. Two radiocarbon ages from the youngest units involved in this deformation result in ages that, at a two-sigma confidence level, are indistinguishable from Modern with age ranges of 310-0 cal BP and 300-0 cal BP (samples GMT-T1-06 and GMT-T1-05, respectively). This indicates the most recent event on the Giant Moletrack segment of the Cathedral Rapids fault occurred sometime after 1,650 AD.

A review of recent seismicity in the region shows at least seven earthquakes with mechanisms compatible with slip on the down-dip projection of the Cathedral Rapids fault have been recorded (AEIC earthquake catalog; Natasha Ruppert, written commun., 2010) (fig. 27). These earthquakes further support the interpretation that the Cathedral Rapids fault is active.

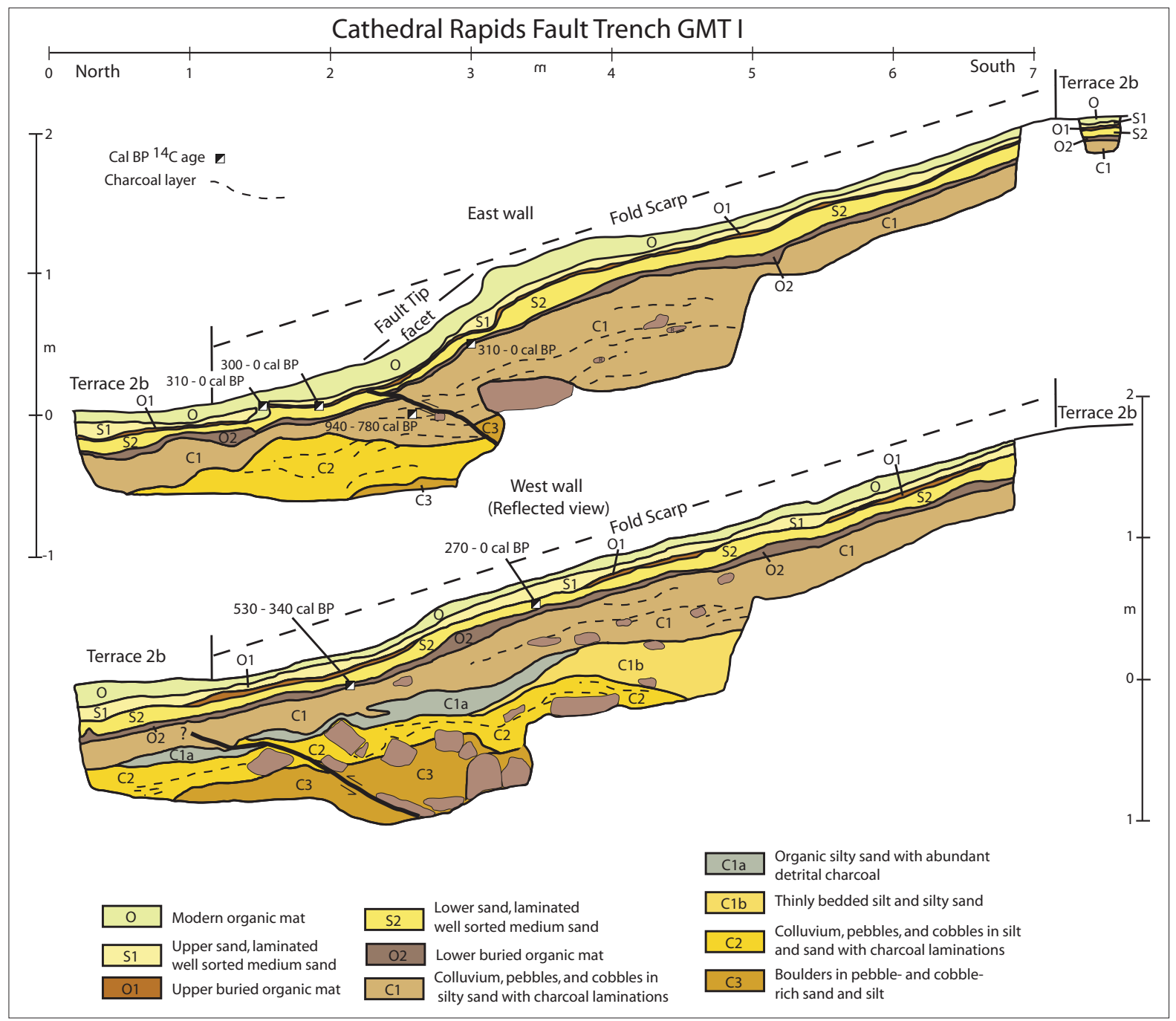

Figure 26. Log of trench GMT I. The fault offsets all strata in the trench except uppermost thin fluvial sand (S1) and surface organic mat (O). Radiocarbon ages of 310-0 and 300-0 cal BP from the faulted organic layer O1 are minimum limiting ages for slip on the fault and show most recent activity of the Cathedral Rapids fault at this site postdates $A D 1650$. 
The Cathedral Rapids fault appears to be the easternmost active thrust in the NFFTB. Our mapping indicates the active range-front folds and thrust faults do not continue east of the Tok River. Reconnaissance of the range front between the Tok River and the Canada border found no evidence of late Quaternary thrust faulting. It is interesting to note that the eastern end of the NFFTB is directly north of the junction of the Denali and Totschunda faults (fig. 2). We speculate that slip on the Totschunda fault, which intersects the Denali fault at an angle of about $20^{\circ}$, results in a north-directed component of compression across the Denali fault west of the intersection. This compression is partitioned across the Denali fault onto the NFFTB and drives the thrusting and folding along the north flank of the Alaska Range (Haeussler, 2008; Bemis and Wallace, 2007). East of the Totschunda-Denali fault intersection, the eastern segment of the Denali fault crosses to the northern side of the range and is purely dextral strike-slip. GPS velocity vectors suggest little compression is occurring across the range east of the Tok River (Freymueller and others, 2008).

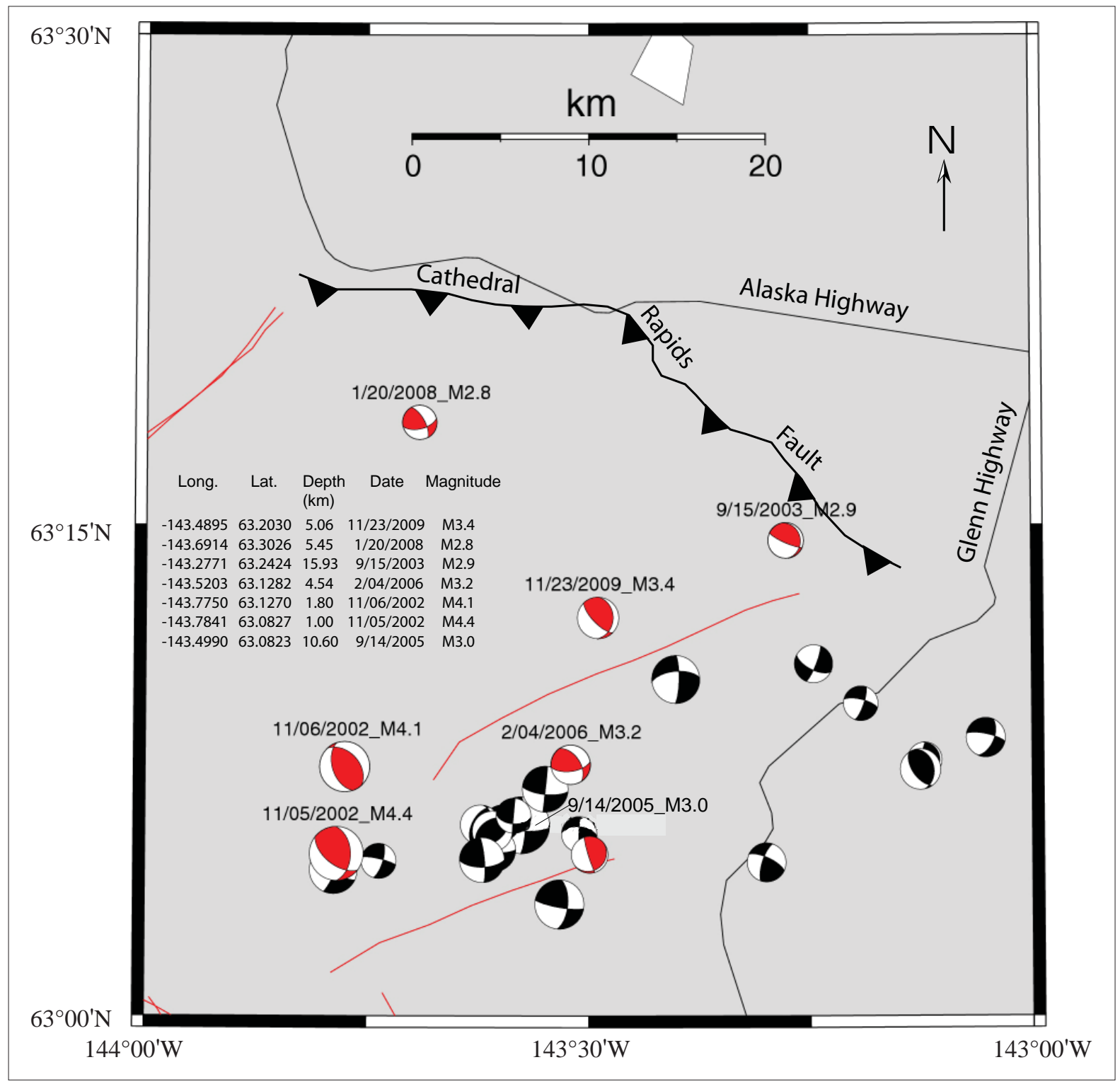

Figure 27. Focal mechanisms (red) for recent earthquakes that have locations, depths, and mechanisms compatible with slip on the down-dip extension of the Cathedral Rapids fault. (AEIC earthquake catalogue; Natasha Ruppert, written commun., 2009). 


\section{MANSFIELD CREEK LINEAMENTS}

The Mansfield Creek lineaments include several northeast-trending linear breaks in slope and scarps in the Mansfield Creek drainage north of the Tanana River (fig. 3). These lineaments are shown on the Neotectonic Map of Alaska (Plafker and others, 1994) and classified as "Suspicious-Age of fault or lineament displacement is unknown. Nearby shallow seismicity, and/or known faults with similar orientation indicates the possibility of Neogene displacement.” The trend of the Mansfield Creek lineaments is similar to that of the Billy Creek fault, a documented active fault located north of the Tanana River about $32 \mathrm{~km}$ to the northwest (Carver and others, 2008).

We conducted helicopter reconnaissance and limited surface studies of these features and excavated one trench across a southeast-facing 1.5-m-high scarp on the most prominent lineament.

The reconnaissance showed the lineaments include several semi-continuous linear alignments of distinct vegetation contrasts between black spruce trees and grassy tundra, down-slope facing side-hill scarps locally up to $10 \mathrm{~m}$ high, and springs. These linear features were most prominent on gentle slopes along the northwestern side of the Mansfield Creek drainage where the bedrock was mantled by thin colluvium (fig. 28). The lineaments were discontinuous and did not extend across thicker alluvium and colluvium in small southeast-trending intermittent tributary drainages to Mansfield Creek.

The trench was sited across a well-defined 1.5-m-high southeast-facing scarp on the most continuous and prominent lineament about $4.8 \mathrm{~km}$ north-northeast of Mansfield Lake (figs. 3 and 28). The trench exposed pervasively weathered and intact horizontally interlayered muscovite schist and quartzite (fig. 29). A mantle of thin layers of colluviums, a weak A-C soil horizon, and organic silt (loess) unconformably overlies the bedrock. The interlayered bedrock crosses the scarp with no evidence of faulting, and the unconformable contact between the bedrock and overlying colluviums was not offset. No evidence of a fault was found in the trench. We interpret the scarp at the trench site to be the result of differential erosion of the resistant layers of quartz and soft-weathered schist. We conclude the Mansfield Creek lineaments reflect differential erosion of the bedrock underlying the slopes in the Mansfield Creek drainage. While some of the lineaments may be the surface expression of bedrock faults, they are not expressed in the valley fill alluvium where they trend across drainages containing young alluvial sediments. We do not believe these lineaments are active faults.

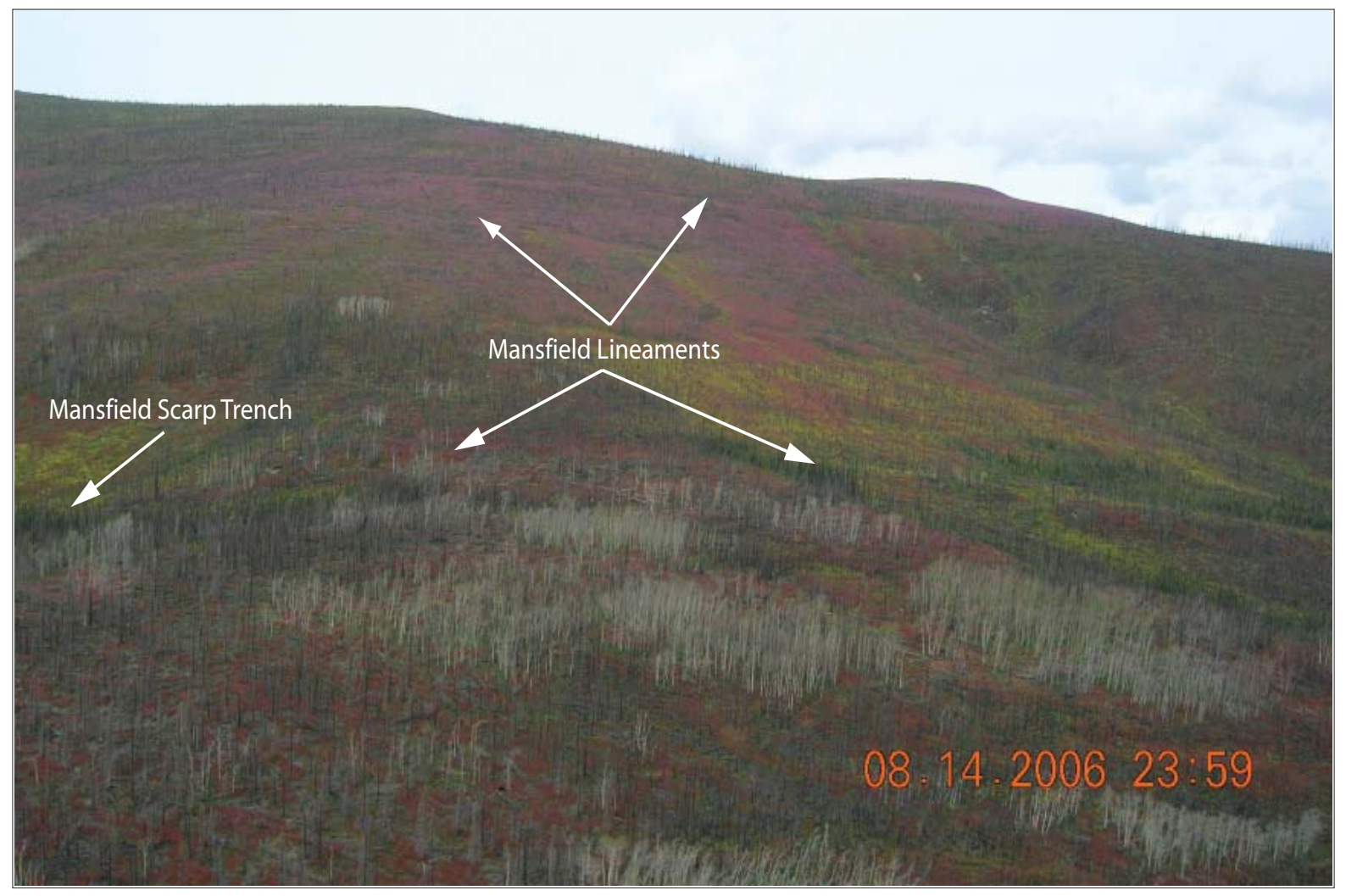

Figure 28. Oblique air photo of the Mansfield lineaments and the Mansfield trench site. View is to the northwest. 


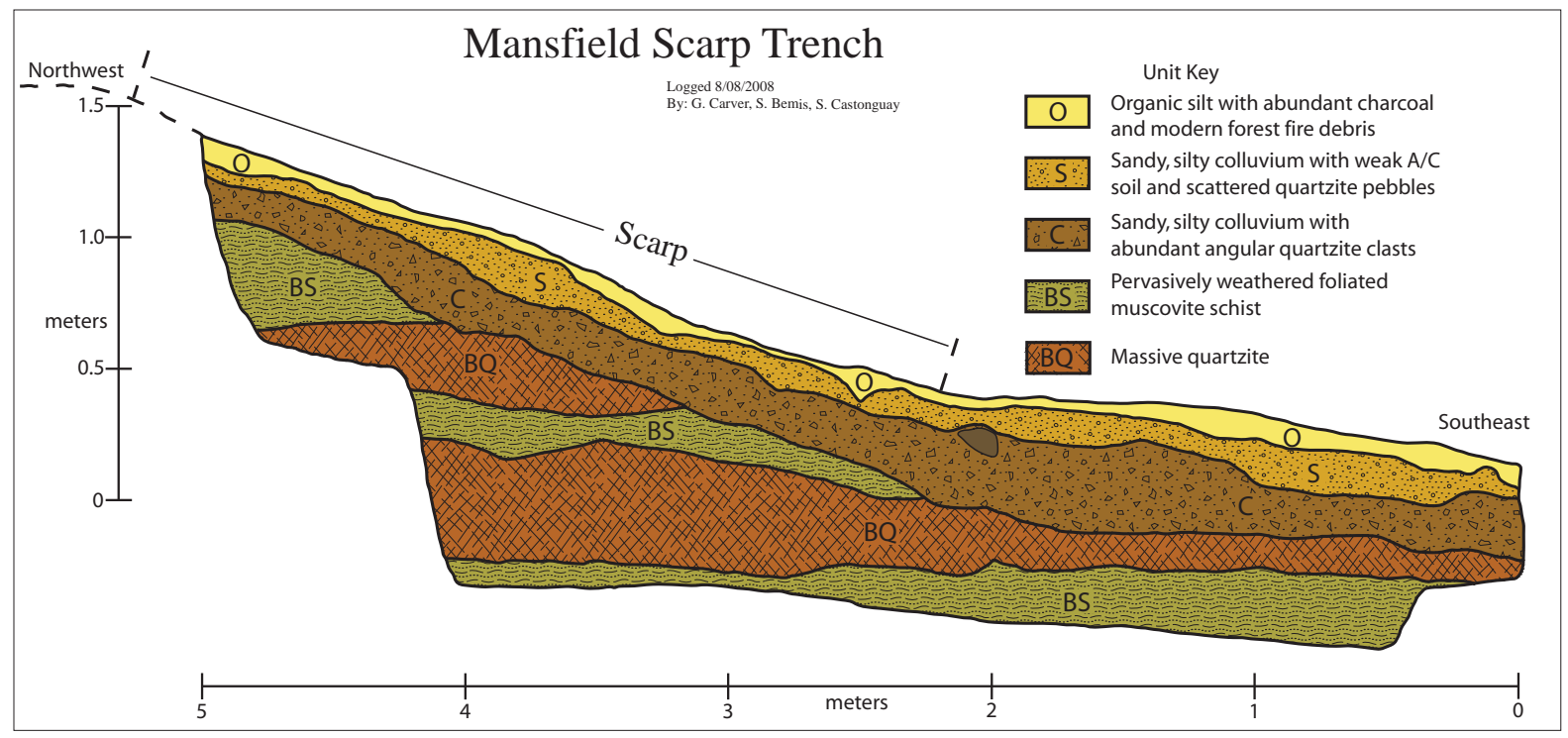

Figure 29. Mansfield scarp trench log. Contacts between the shist (BS) and quartzite layers (BQ) in the bedrock and the overlying colluvial $(C)$, loess $(O)$, and soil $(S)$ units are not offset where they cross the base of the scarp that defines the Mansfield lineament at this location, showing the scarp is not the result of faulting.

\section{DENNISON FORK LINEAMENT-TOK RIVER VALLEY}

Plafker and others (1994) show the Dennison Fork lineaments on their Neotectonic Map of Alaska as several "suspicious" northeast-trending lineaments along the west margin of the Tok River valley south of Tok and along the upper reaches of the Dennison Fork of the Fortymile River northeast of Tok (fig. 3). During the 2008 field season we conducted helicopter reconnaissance of these lineaments in the upper Dennison Fork of the Fortymile River area and a detailed investigation of the most prominent of the lineaments in the upper Tok River valley.

The Dennison Fork lineaments northeast of Tok are similar to the Mansfield Creek lineaments, characterized by linear vegetation contrasts, side-hill scarps, and spring lines. The lineaments terminate where they intersect valley fill deposits in small drainages. We found no evidence that these lineaments are youthful faults that offset Holocene landforms or deposits.

Along the west margin of the upper Tok River valley, the Dennison Creek lineament crosses several alluvial fans where small, unnamed tributaries to the Tok River enter the valley. A single prominent northeast-trending, east-facing scarp is present on each of these alluvial fans (fig. 30). These scarps are up to $10 \mathrm{~m}$ high. A similar discontinuous west-facing scarp is present on the east margin of the Tok River valley. This scarp defines one of several lineaments that make up the Caribou Creek lineaments shown as "suspicious" (possible active faults) on the Neotectonic Map of Alaska (Plafker and others, 1994). The scarps on both sides of the valley closely follow the valley margin and are at similar elevations above the valley floor.

We excavated two trenches across the Dennison Fork lineament on the west side of the Tok River valley about $3.7 \mathrm{~km}$ west-southwest of the Glenn Highway bridge across the Tok River (fig. 30). The trenches were excavated across the base of a 4-m-high scarp on a large alluvial fan where a small, unnamed south-flowing creek enters the Tok River valley. Both trenches exposed stacked sequences of debris-flow deposits interbedded with thin layers of loess deposited against alluvial fan sediments at the base of the scarp (figs. 31-33). Contacts between the debris flows and intervening layers of loess were not faulted where they crossed the scarp. No evidence of faulting was found in the trenches.

Reger and others (2009) present evidence of large glacial-outburst floods, probably originating from glacial lake Atna, which repeatedly flowed down the Tok River valley during the Donnelly glaciation. We propose that these floods removed the distal parts of the alluvial fans on the margins of the valley and eroded scarps into the heads of the fans. The toes of these scarps have subsequently been buried during severe storm events by debris flows, alluvium, and colluvium derived from the fan heads above the scarps. Between episodes of debris-flow deposition, loess accumulated on the deposits. $\mathrm{A}{ }^{14} \mathrm{C}$ age of 1,510-1,310 cal BP was obtained from the stratigraphically lowest layer of buried loess in the debris-flow sequence in trench II, demonstrating a Holocene age for the debris flows 


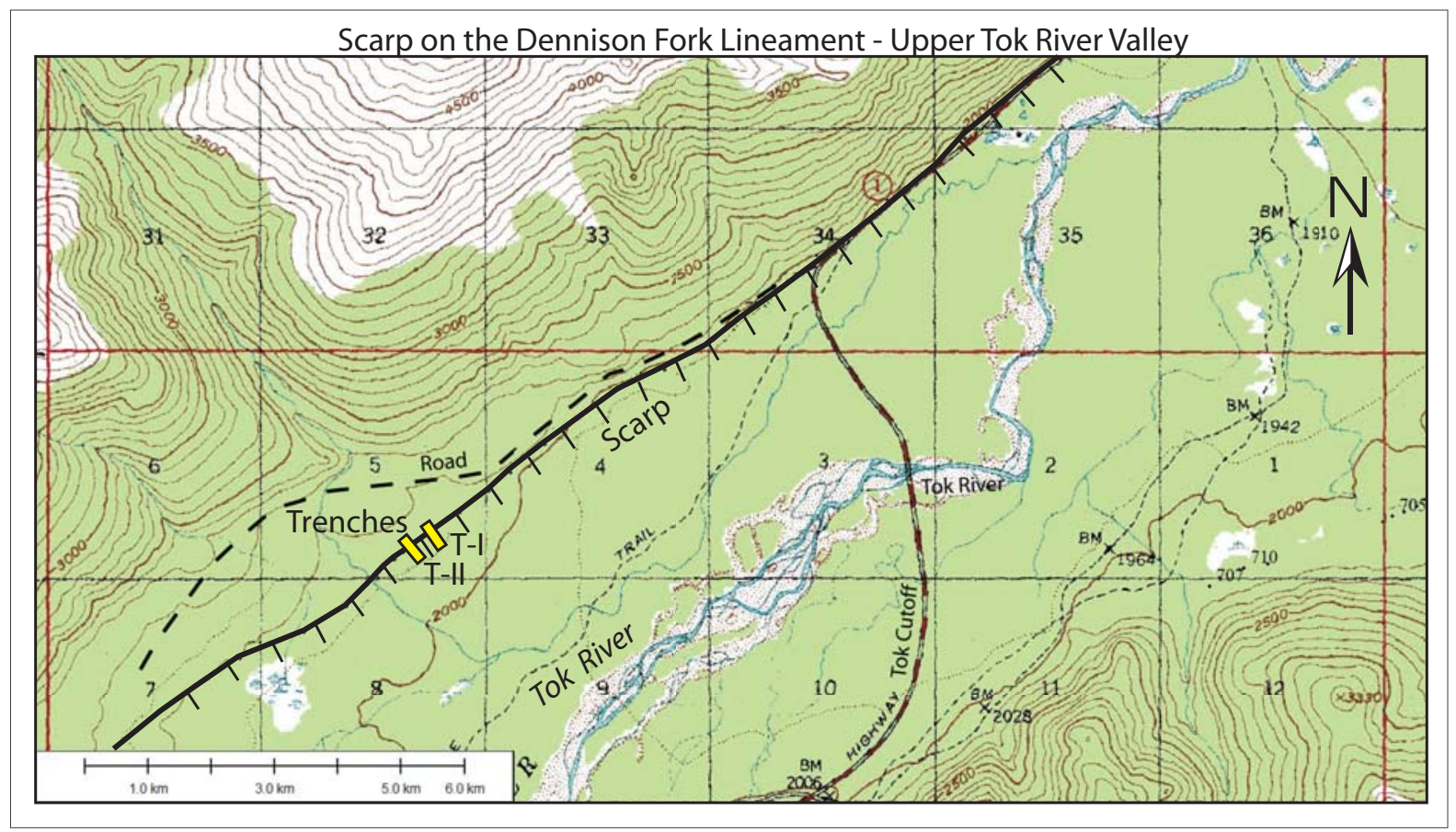

Figure 30. Scarp and trench locations on the Dennison Fork lineament in the upper Tok River valley..

that postdate the scarp. We conclude that the Dennison Fork lineament in the Tok River valley is a product of erosion by late Pleistocene glacial outburst floods and is not associated with faulting. Based on its similar elevation and geomorphic expression we also interpret the Caribou Hills lineament on the east side of the Tok River valley to be a glacial outburst flood scarp.

\section{CONCLUSIONS}

Field investigations of active and potentially active faults in and near the Alaska Highway corridor in 2008 included excavation of two trenches on the eastern segment of the Dot "T" Johnson fault. This fault was first mapped in 2007 (Carver and others, 2008). Additionally a previously unknown active fault, which we named the Cathedral Rapids fault, and an associated active fault-generated anticline, named the Giant Moletrack anticline, were identified during this study. The Cathedral Rapids fault is a low-angle thrust that trends along the south margin of the Tanana River valley at the base of the Alaska Range foothills east of the Dot "T" Johnson fault. The Cathedral Rapids fault and its associated Giant Moletrack anticline are the easternmost active structures in the eastern extension of the NFFTB. Field reconnaissance, mapping, and trenching were also conducted on three suspected active faults, the Bear Creek, Mansfield Creek, and Dennison Fork lineaments.

Paleoseismic investigation of the Dot "T" Johnson fault in 2007 showed the fault generated two episodes of latest Pleistocene and early Holocene displacement, each with more than $3 \mathrm{~m}$ of dip-slip displacement (Carver and others, 2008). The earlier of the two slip events dated to between 12,100-11,700 cal BP and 12,380-11,980 cal BP. The maximum age of the second slip event is constrained by a ${ }^{14} \mathrm{C}$ date of 9,740-9,540 cal BP. The minimum age for this event is unconstrained (Carver and others, 2008). The two trenches excavated across the Dot "T" Johnson fault in 2008 added to the paleoseismic record for the fault and improved understanding of its slip parameters. The Sears Creek trench revealed an additional slip event on the Dot "T" Johnson fault that dated to between 4,430-3,230 cal BP and 680-560 cal BP. This event produced about $3 \mathrm{~m}$ of dip-slip displacement.

Trench D“T”J III showed several displacement events with the most recent occurring after 7,980-7,850 cal BP. Earlier events predate the 7,980-7,850 cal BP age but their timing is not well constrained. The presently available paleoseismic data for the Dot "T" Johnson fault suggests it has a recurrence interval of several thousand years and that it generates about 3-4 m of dip-slip displacement per event. Its Holocene dip-slip displacement rate is approximately $1 \mathrm{~mm} / \mathrm{yr}$.

Structural analysis of the complex faulting pattern in the hanging wall of the fault exposed in D“T”J III trench shows the displacement on the thrust is nearly pure dip-slip and the orientation of the principal compression axis 


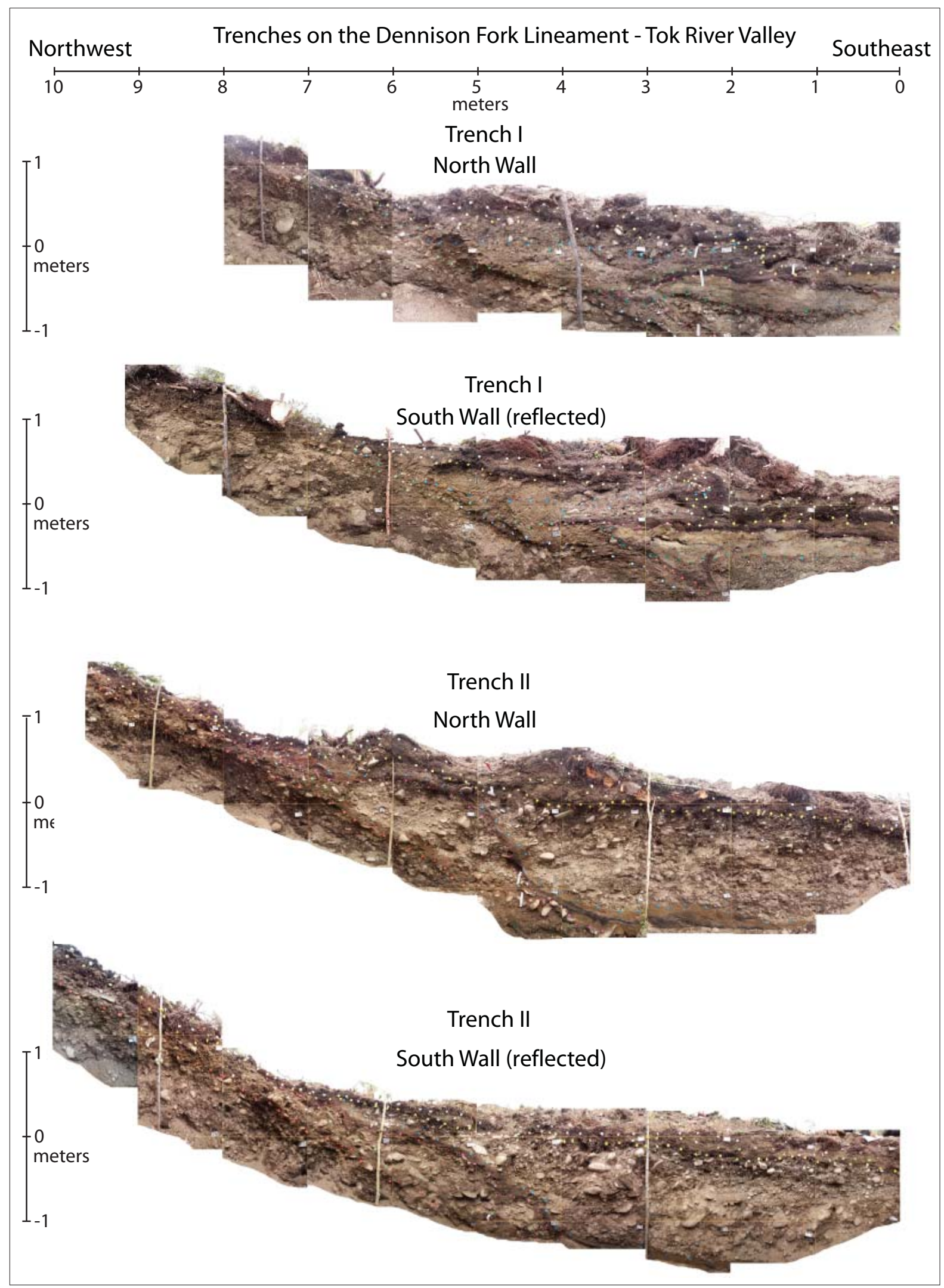

Figure 31. Photo mosaics of trenches across the Dennison Fork lineament scarp in the upper Tok River valley. 


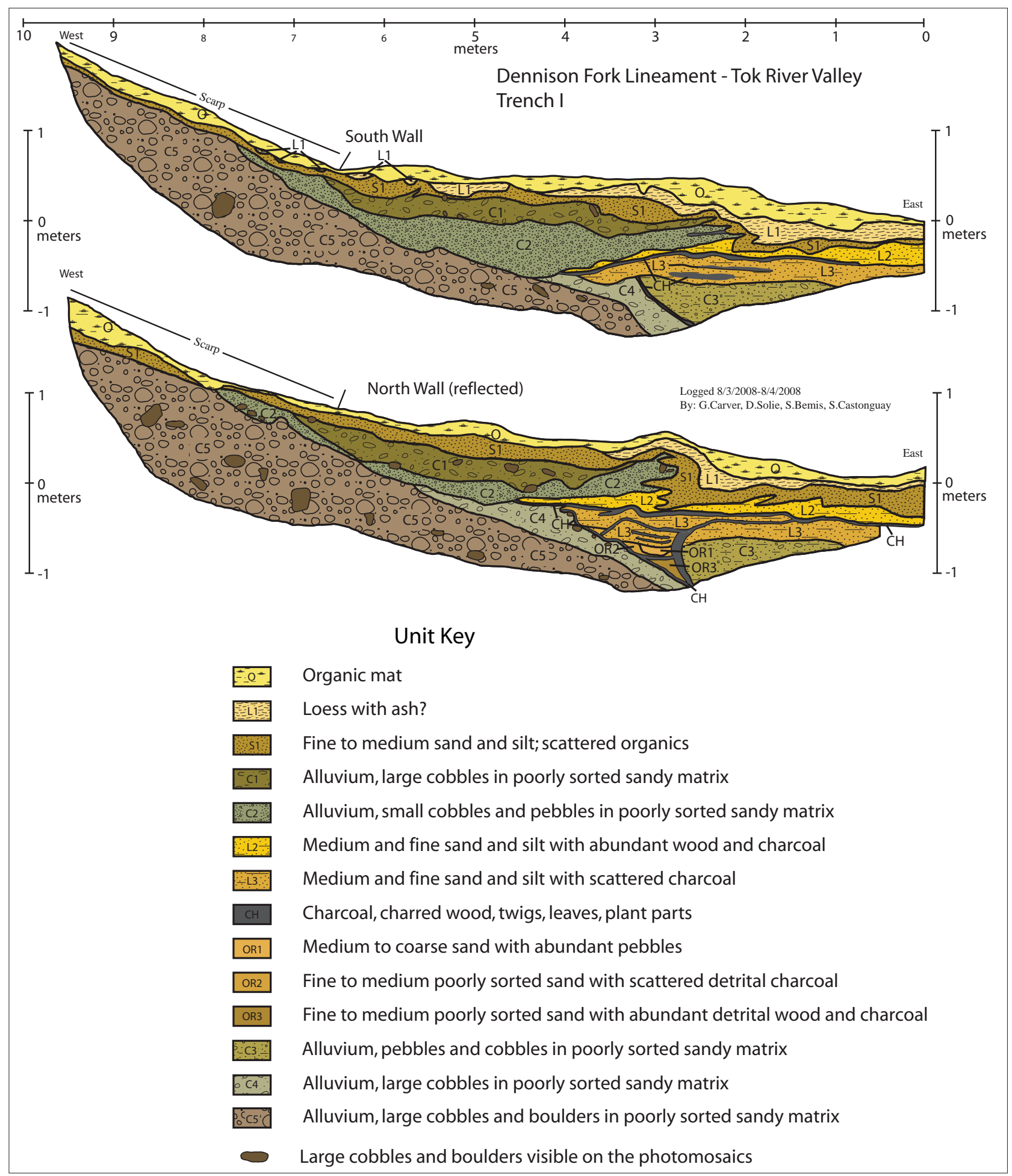

Figure 32. Log of trench I across the base of the Dennison Fork lineament scarp in the upper Tok River valley. No evidence of faulting was found in the trench. 


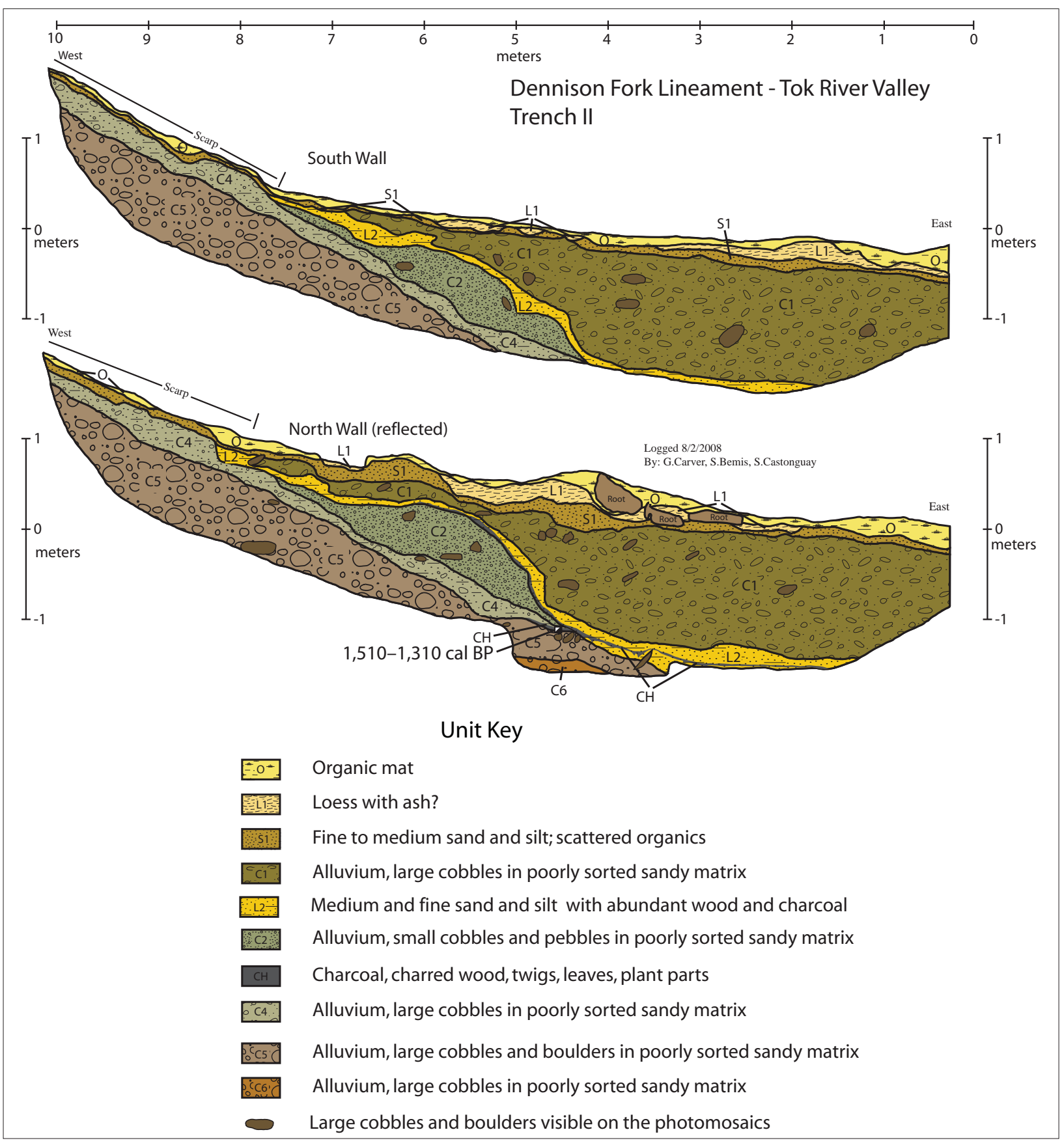

Figure 33. Log of trench II across the base of the Dennison Fork lineament scarp in the upper Tok River valley. No evidence of faulting was found in the trench. 
nearly north-south. Although this general interpretation is evident from the other trenches we have studied on this fault, the measurements of secondary conjugate faults in the hanging wall and the micro-faults and shears in the principal thrust zone exposed in trench D“T"J III allowed quantification of this parameter. The azimuth of the principal compression axis across the fault (sigma 1 ) is north $332^{\circ}$ to $339^{\circ}$.

The Cathedral Rapids fault is a 37-km-long, low-angle, south-dipping thrust fault in the eastern part of the range-front thrust system on the south margin of the Tanana River valley. It is separated from the Dot "T" Johnson fault by the Robertson River step-over; a $20 \mathrm{~km}$ right step in the range front, the Tanana River valley, and the thrust system. Faults crossing the step-over and connecting the Dot "T" Johnson and Cathedral Rapids faults have not been identified and the mechanics of the right step in the range-front thrust system are not well understood. The Cathedral Rapids fault is mapped from near Sheep Creek southwest of Cathedral Rapids on the Tanana River east to near the Tok River. The eastern $16 \mathrm{~km}$ of the fault has a prominent fault-generated anticline in the hanging wall, the Giant Moletrack anticline. Scarps along the fault and folded terraces bordering streams crossing the anticline show late Pleistocene and Holocene activity. The paleoseismic record of the Cathedral Rapids fault is deduced from trench studies of a faulted stream terrace and a bending-moment graben in the crest of the anticline. Four Holocene slip events are recognized. Three of these are interpreted from upward terminations of fault traces in deformed sediments that fill the bending-moment graben. Radiocarbon ages that bracket these paleoearthquakes include: event 1 (oldest), greater than 12,230-11,630 cal BP; event 2, 11,120-10,610 cal BP to 10,290-10,220 cal BP; event 3, 10,290-10,220 cal BP to 8,600-8,430 cal BP. The most recent surface faulting is interpreted from the trench across a faulted late Holocene stream terrace and dates to more recent than AD 1650. This event generated about $4 \mathrm{~m}$ of dip-slip displacement on the fault in the shallow subsurface and offset the terrace vertically about 2 $\mathrm{m}$. While this paleoseismic record is likely incomplete, it shows the recurrence interval; the single-event displacement and slip rate of the Cathedral Rapids fault are in general similar those of the Dot "T" Johnson fault.

Two of the three lineaments investigated in 2008, the Mansfield Creek and Dennison Fork lineaments, displayed no evidence of faulting in trenches excavated across well defined scarps. The third, the Bear Creek lineament in the Robertson River step-over, was also trenched but the exposure failed to provide definitive evidence regarding the presence or absence of a fault.

In summary, our investigations of active and potentially active faults in and near the Alaska Highway corridor have shown the principal active structures are low-angle, south-dipping thrust faults that make up the eastern part of the NFFTB. This system of thrust faults is divided into three segments separated by large lateral steps. From west to east the segments are the Granite Mountain and Dot Lake segments of the Dot "T" Johnson fault, and the Cathedral Rapids fault segment. The segments are about 30, 50, and $37 \mathrm{~km}$ long, respectively. The two segments of the Dot "T" Johnson fault are joined by the Canteen fault, a left-lateral tear fault in the upper thrust sheet of the NFFTB (Carver and others, 2008). The structural nature of the step between the Dot "T" Johnson and Cathedral Rapids faults has not been identified. No other active faults were found in the central part of the corridor. Several lineaments, identified as possible active faults in earlier studies, including the Mansfield and the Dennison Fork lineaments, were investigated and found not to be active faults.

\section{ACKNOWLEDGMENTS}

This project is funded by the State of Alaska and managed by the Alaska Division of Geological \& Geophysical Surveys. We thank Peter Haeussler (USGS) and Gordon Seitz (San Diego State University) for their insightful field reviews of the Dot “T” Johnson trench III and Sears Creek trench. Valuable discussions with Richard D. Reger (Reger Geologic Consulting), Trent D. Hubbard and De Anne Stevens, (DGGS), Robert F. Swenson (DGGS Director and State Geologist), and Rodney A. Combellick (DGGS Deputy Director) are gratefully acknowledged. We also appreciate suggestions and insight provided by the DGGS bedrock-mapping group, Joe Andrews, Larry Freeman, and Melanie Werdon. The skill, experience, and ability of our helicopter pilot, Tom "Rat" Ratledge contributed immeasurably to our field effort. The hospitable owners and operators of the Cathedral Creeks B\&B, Chris Bentele and Dave Thorp, provided excellent meals and comfortable camp facilities. Richard Koehler reviewed the manuscript, and we appreciate his constructive and insightful comments. 


\section{REFERENCES}

AEIC, Alaska Earthquake Information Center, AEIS Earthquake Database Search, http://www.aeic.alaska.edu/ html docs/db2catalog.html.

Amos, C.B., Burbank, D.W., Nobes, D.C., and Read, S.A.L., 2007, Geomorphic constraints on listric thrust faulting; Implications for active deformation in the Mackenzie Basin, South Island, New Zealand: Journal of Geophysical Research, v. 112, issue B3.

Bemis, S.P., 2004, Neotectonic framework of the north-central Alaska Range foothills: Fairbanks, Alaska, University of Alaska Fairbanks, unpublished M.S. thesis, 142 p.

2006, Overview of Quaternary structures and deformation of the Northern Foothills Fold and Thrust Belt, central Alaska Range, Alaska [abs]: American Geophysical Union Chapman Conference on Active Tectonics and Seismic Potential of Alaska, Abstracts with program, 11-14 May, Alyeska Resort, Girdwood, Alaska, p. 41.

Bemis, S.P., and Wallace, W.K., 2007, Neotectonic framework of the north-central Alaska Range foothills, in Ridgway, K.D., Trop, J.M., Glen, M.G., and O’Neill, J.M., eds., Tectonic growth of a collisional continental margin; Crustal evolution of southern Alaska: Geological Society of America Special Paper 431, p. 549-572.

Carrara, P.E., 2004, Surficial geologic map of the Tanacross B-5 Quadrangle, east-central Alaska: U.S. Geological Survey Scientific Investigations Map 2856, version 1.0, 9 p., 1 plate, scale 1:63,360.

Carter, L.D., and Galloway, J.P., 1978, Preliminary engineering geologic maps of the proposed natural gas pipeline route in the Tanana River valley, Alaska: U.S. Geological Survey Open-file Report 78-794, 26 p., 3 plates, scale $1: 125,000$.

Carver, G.A., and McCalpin, J.P., 1996, Paleoseismology of compressional tectonic environments - Chapter 5, in McCalpin, J.P., ed., Paleoseismology: New York, Academic Press, International Geophysics Series, v. 62, p. 183-270.

2009, Paleoseismology of Compressional Tectonic Environments - Chapter 5; in McCalpin, J.P., ed., Paleoseismology, $2^{\text {nd }}$ Edition, International Geophysical Series, v.95, Elsevier, Burlington, MA., p. 315-419.

Carver, G.A., Plafker, George, Metz, M.C., Cluff, Lloyd, Bemis, S.P., Roddick, Jim, Redington, J., and Sorensen, Steve, 2006, Late Quaternary growth of thrust faults and associated folds in the eastern part of the Northern Foothills Fold and Thrust Belt, central Alaska Range, Alaska: [abs], American Geophysical Union Chapman Conference on Active Tectonics and Seismic Potential of Alaska, Abstracts with program, 11-14 May, Alyeska Resort, Girdwood, Alaska, p. 42-43.

Carver, G.A., Plafker, George, Metz, M.C., Cluff, Lloyd, Slemmons, Burt, Johnson, Elden, Roddick, Jim, Sorensen, Steve, 2004, Surface rupture on the Denali fault interpreted from tree damage during the 1912 Delta River $\mathrm{M}_{\mathrm{w}}$ 7.2-7.4 Earthquake; Implications for the 2002 Denali fault earthquake slip distribution, in Rowe, C.A., Christensen, Douglas, and Carver, G.A., eds., The 2002 Denali fault earthquake sequence, dedicated issue: Bulletin of the Seismological Society of America, v. 94B, p. S58-S71.

Carver, G.A., Bemis S.P., Solie, D.N., and Obermiller, K.E., 2008, Active and potentially active faults in or near the Alaska Highway corridor, Delta Junction to Dot Lake, Alaska: Alaska Division of Geological \& Geophysical Surveys Preliminary Investigative Report 2008-3d, 32 p.

Chapman, J.B., Pavlis, T.L., Gulick, S.P.S., Berger, A.L., Lowe, Lindsay, Spotila, J.A., Bruhn, Ronald, Vorkink, Michael, Koons, Peter, Barker, Adam, Picornell, Carlos, Ridgway, K.D., Hallet, Bernard, Jaeger, J.M., and McCalpin, J.P., 2008, Neotectonics of the Yakutat collision; Changes in deformation driven by mass redistribution, in Freymueller, J.T., Haeussler, P.J., Wesson, R.L., and Ekstrom, Goran, eds., Active tectonics and seismic potential of Alaska: American Geophysical Union Geophysical Monograph Series, v. 179, p. 65-82.

Doser, D.I., 2004, Seismicity of the Denali-Totschunda fault zone in central Alaska (1912-1988) and its relation to the 2002 Denali fault earthquake sequence, in Rowe, C.A., Christensen, Douglas, and Carver, G.A., eds., The 2002 Denali fault earthquake sequence, dedicated issue: Bulletin of the Seismological Society of America, v. 94, no. 6B, p. S132-S144.

Eberhart-Phillips, Donna, Haeussler, P.J., Freymueller, J.T., Frankel, A.D., Rubin, C.M., Craw, P.A.C., Ratchkovski, N.A., Anderson, Greg, Carver, G.A., Crone, A.J., Dawson, T.E., Fletcher, Hilary, Hansen, R.A., Harp, E.L., Harris, R.A., Hill, D.P., Hreinsdottir, Sigrun, Jibson, R.W., Jones, L.M., Kayen, R.E., Keefer, D.K., Larsen, C.F., Moran, S.C., Personius, S.F., Plafker, George, Sherrod, B.L.,Sieh, Kerry, Sitar, Nicholas, and Wallace, W.K., 2003, The 2002 Denali fault earthquake, Alaska; A large magnitude, slip partitioned event: Science, v. 300, issue 5622, p. 1,113-1,118.

Foster, H.L., 1970, Reconnaissance geologic map of the Tanacross quadrangle, Alaska: U.S. Geological Survey Miscellaneous Geologic Investigations Map I-593, 1 plate, scale 1:250,000. 
Freymueller, J.T., Woodard, Hilary, Cohen, S.C., Cross, R.S., Elliot, Julie, Larsen, C.F., Hreinsdottir, Sigrun, and Zweck, Chris, 2008, Active deformation processes in Alaska, based on 15 years of GPS measurements; in Freymueller, J.T., Haeussler, P.J., Wesson, R.L., and Ekstrom, Goran, eds., Active tectonics and seismic potential of Alaska: American Geophysical Union, Geophysical Monograph Series, v. 179, p. 1-42.

Haeussler, P.J., 2008, An overview of the neotectonics of interior Alaska: Far-field deformation from the Yakutat microplate collision; in Freymueller, J.T., Haeussler, P.J., Wesson, R.L., and Ekstrom, Goran, eds., Active tectonics and seismic potential of Alaska: American Geophysical Union, Geophysical Monograph Series, v. 179, p.83-108.

Lesh, M.E., and Ridgway, K.D., 2007, Geomorphic evidence of active transpressional deformation in the Tanana foreland basin, south-central Alaska; in Ridgway, K.D., Trop, J.M., Glen, J.M.G., and O’Neill, J.M., eds., Tectonic growth of a collisional continental margin; Crustal evolution of southern Alaska: Geological Society of America Special Paper 431, p. 573-592.

Matmon, Ari, Schwartz, D.P., Haeussler, P.J., Finkel, R., Lienkaemper, J.J., Stenner, H.D., and Dawson, T.E., 2006, Denali fault slip rates and Holocene-late Pleistocene kinematics of central Alaska: Geology, v. 34, no. 8, p. 645-648.

Page, R.A., Plafker, George, and Pulpan, Hans, 1995, Block rotation in east-central Alaska; A framework for evaluating earthquake potential?: Geology, v. 23, no. 7, p. 629-632.

Plafker, George, Gilpin, L.M., and Lahr, J.C., 1994, Neotectonic map of Alaska: in Plafker, George, and Berg, H.C., eds., The geology of Alaska: Boulder, Colorado, Geological Society of America, Geology of North America, v. G-l, 12 plates, scale 1:2,500,000.

Ratchkovski, N.A., and Hansen, R.A., 2002, New constraints on tectonics of interior Alaska; Earthquake locations, source mechanism, and stress regime: Bulletin of the Seismological Society of America, v. 92, p. 998-1,014.

Reger, R.D., Hubbard, T.D., and Carver, G.A., 2009, Surficial geology of the Alaska Highway corridor, Robertson River to Tetlin Junction, Alaska: Alaska Division of Geological \& Geophysical Surveys Preliminary Investigative Report 2009-6a, in press.

Reimer, P.J., Baillie, M. G. L., Bard, Edouard, Bayliss, Alex, Beck, J.W., Bertrand, J.H., Blackwell, P.G., Buck, C.E., Burr, G.S., Cutler, K.B., Damon, P.E., Edwards, R.L., Fairbanks, R.G., Friedrich, Michael, Guilderson, T.P., Hogg, A.G., Hughen, K.A., Kromer, Bernd, McCormac, Gerry, Manning, Sturt, Ramsey, C.B., Reimer, R.W., Remmele, Sabine, Southon, J.R., Stuiver, Minze, Talamo, Sahra, Taylor, F.W., van der Plicht, Johannes, and Weyhenmeyer, C.E., 2004, IntCa104 terrestrial radiocarbon age calibration, 0-26 cal kyr BP: Radiocarbon, v. 46, no. 3, p. 1,029-1,058.

Ridgway, K.D., Trop, J.M, Nokleberg, W.J., Davidson, C.M., and Eastham, K.R., 2002, Mesozoic and Cenozoic tectonics of the eastern and central Alaska Range; Progressive basin development and deformation in a suture zone: Geological Society of America Bulletin, v. 114, no. 12, p. 1,480-1,504.

Ruppert, N.A., Ridgway, K.D., Freymueller, J.T., Cross, R.C., and Hansen, R.A., 2008, Active tectonics of interior Alaska; Seismology, GPS geodesy, and local geomorphology, in Freymueller, J.T., Haeussler, P.J., Wesson, R.L., and Ekstrom, Goran, eds., Active tectonics and seismic potential of Alaska: American Geophysical Union Geophysical Monograph Series, v. 179, p. 109-133.

Solie, D.N., and Burns, L.E., 2006, Geology, geophysics, and geohazards along the Alaska Highway corridor; A project of the Alaska Division of Geological \& Geophysical Surveys (poster): Yukon Geosciences Forum, November 2006, Whitehorse, Yukon Territory, Canada.

_2007, Alaska Highway corridor geology and geophysics, in Alaska GeoSurvey News: Alaska Division of Geological \& Geophysical Surveys newsletter, NL 2007-1, p. 1-4.

Thoms, E.E., 2005, Neotectonics of the central Alaska Range; A guidebook for the 2005 Alaska Cell, Friends of the Pleistocene field trip, $42 \mathrm{p}$. 



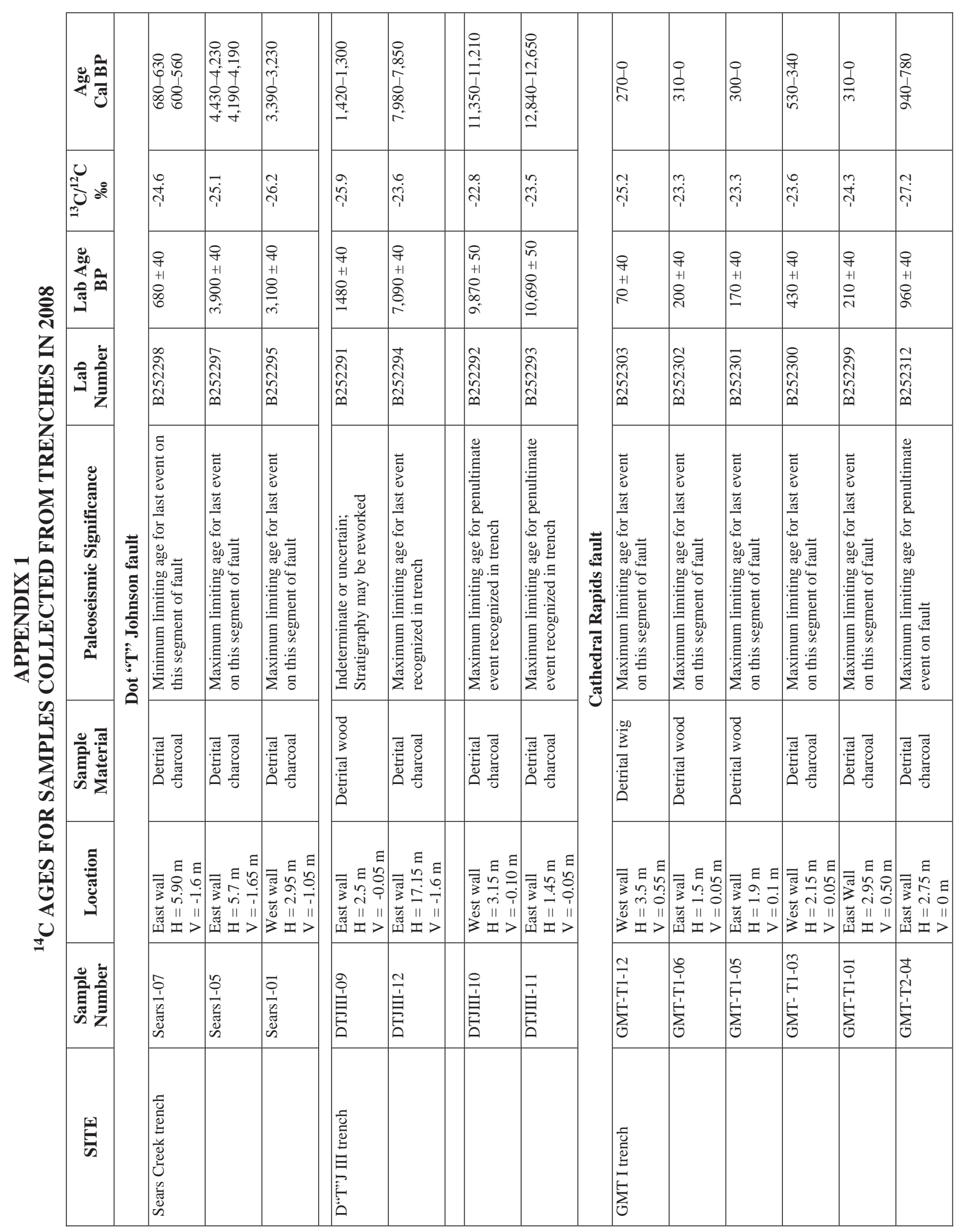




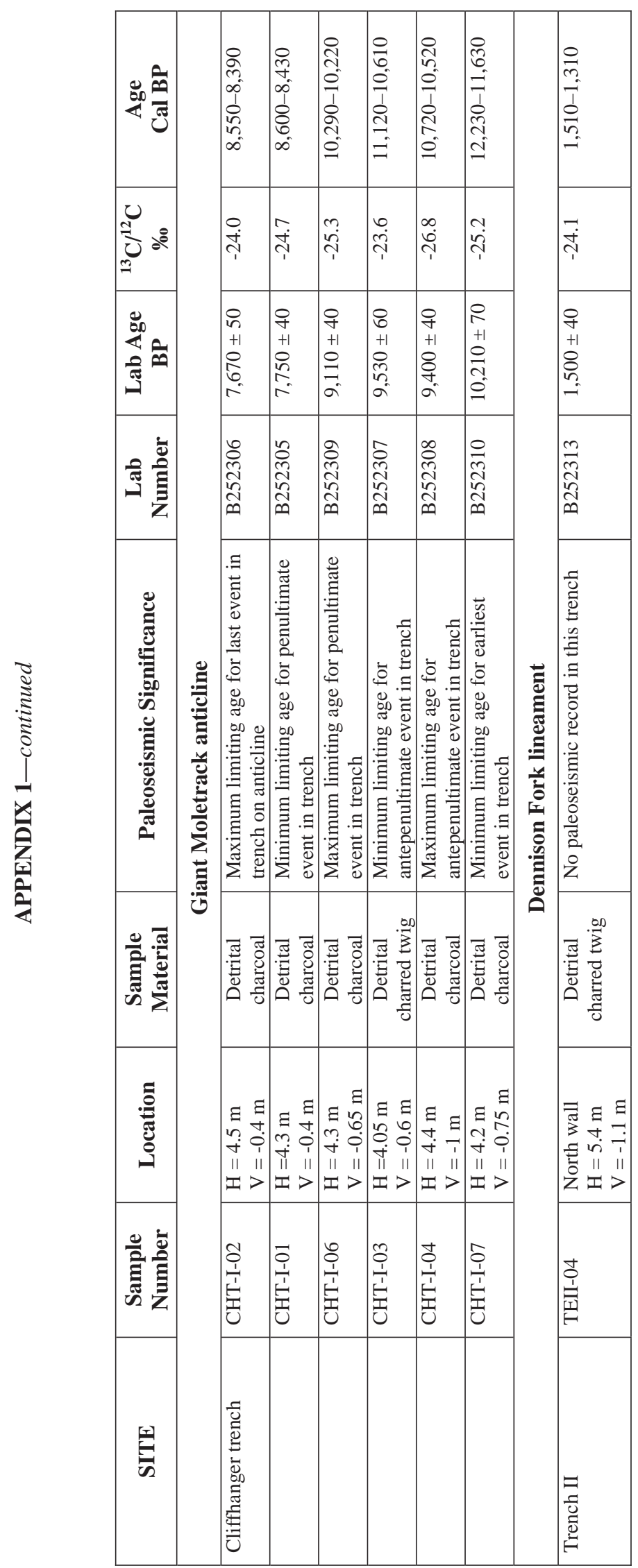

